\title{
Establishing a historic benchmark for rimrock pine communities at New River Gorge National River, West Virginia
}

\author{
Richard Stockton Maxwell \\ West Virginia University
}

Follow this and additional works at: https://researchrepository.wvu.edu/etd

\author{
Recommended Citation \\ Maxwell, Richard Stockton, "Establishing a historic benchmark for rimrock pine communities at New River \\ Gorge National River, West Virginia" (2006). Graduate Theses, Dissertations, and Problem Reports. 3250. \\ https://researchrepository.wvu.edu/etd/3250
}

This Thesis is protected by copyright and/or related rights. It has been brought to you by the The Research Repository @ WVU with permission from the rights-holder(s). You are free to use this Thesis in any way that is permitted by the copyright and related rights legislation that applies to your use. For other uses you must obtain permission from the rights-holder(s) directly, unless additional rights are indicated by a Creative Commons license in the record and/ or on the work itself. This Thesis has been accepted for inclusion in WVU Graduate Theses, Dissertations, and Problem Reports collection by an authorized administrator of The Research Repository @ WVU. For more information, please contact researchrepository@mail.wvu.edu. 
Establishing a Historic Benchmark for Rimrock Pine Communities at New River Gorge National River, West Virginia

\title{
Richard Stockton Maxwell
}

Thesis submitted to the College of Agriculture, Forestry, and Consumer Sciences at West Virginia University in partial fulfillment of the requirements

for the degree of

\author{
Master of Science \\ in \\ Forestry
}

Ray R. Hicks, Jr., Ph.D., Chair

James Rentch, Ph.D.

Amy E. Hessl, Ph.D.

Gary Miller, Ph.D.

Davis College of Agriculture, Forestry, and Consumer Sciences

Division of Forestry and Natural Resources

Morgantown, West Virginia

2006

Keywords: rimrock pine, Pinus virginiana, dendrochronology, fire history

Copyright 2006 Richard Stockton Maxwell 


\begin{abstract}
Establishing a Historic Benchmark for Rimrock Pine Communities at New River Gorge National River, West Virginia
\end{abstract}

\title{
Richard Stockton Maxwell
}

The structure and composition of a rimrock pine community was studied in the New River Gorge National River, West Virginia. A forest survey found that the overstory was dominated by Pinus virginiana, Nyssa sylvatica, Oxydendrum arboreum, Acer rubrum, and Quercus spp. The importance of Pinus virginiana decreased rapidly with increasing distance from the cliff edge and was replaced by hardwood competitors. Regeneration of Pinus virginiana $(\sim 4,200 \mathrm{stems} / \mathrm{ha})$ was deemed inadequate to sustain a pine forest except on the harshest sites near the cliff edge. A 108-year (1897-2005) fire chronology was constructed from 51 fire scars recorded by 23 pines along the rimrock (100 ha). The Weibull median fire interval ranged from 4-8 years when two trees were required to document a fire. Local land use history was determined to be the controlling factor of fire frequency. It is suggested that prescribed burning be used to restore and maintain the rimrock pine forest. 


\section{ACKNOWLEDGEMENTS}

I would like to thank the National Park Service at the New River Gorge National River, West Virginia for funding the study. A special thanks to John Perez, NERI resource manager, for his support of the project and help in the field. Thank you to my advisor, Ray R. Hicks, for taking me as a student and the many opportunities he afforded me in the past two years. Thanks to Jim Rentch for letting me occupy his office for weeks while I measured tree rings. Thanks to Amy Hessl for igniting my interest in fire history and the excellent feedback on my fire history literature review. Thanks to Gary Miller for joining my graduate committee and reviewing my thesis. 


\section{TABLE OF CONTENTS}

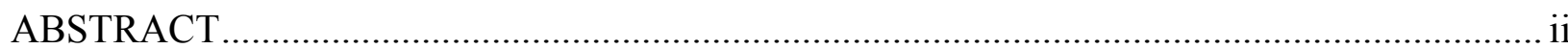

ACKNOWLEDGEMENTS ...........................................................................................

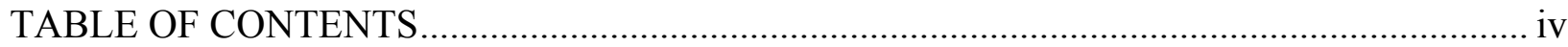

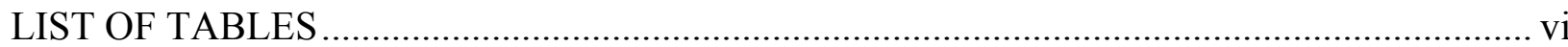

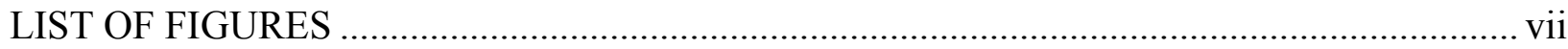

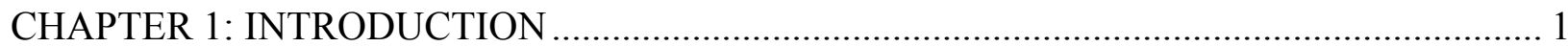

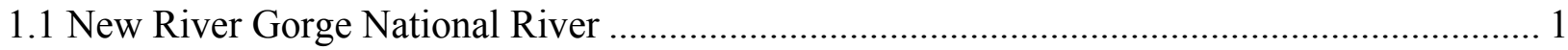

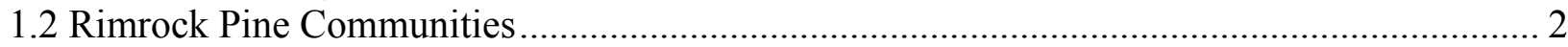

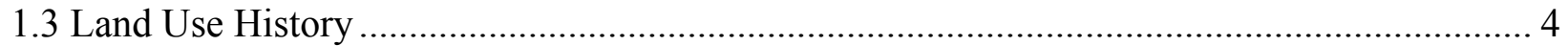

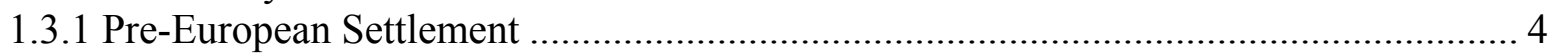

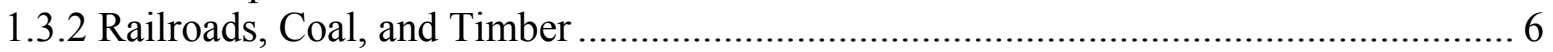

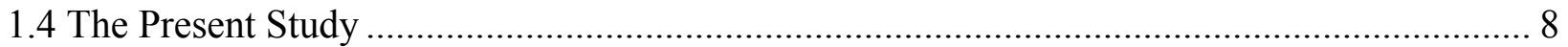

CHAPTER 2: FIRE HISTORY IN THE CENTRAL HARDWOOD FORESTS ........................... 11

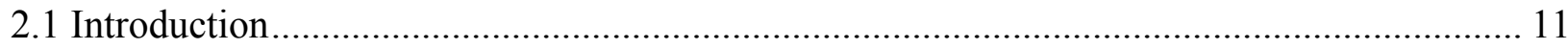

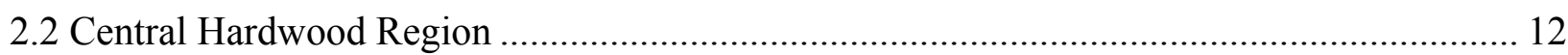

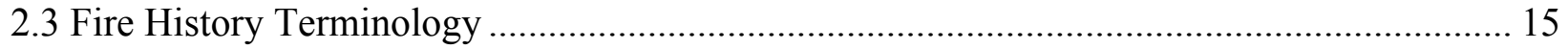

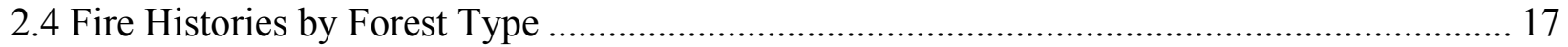

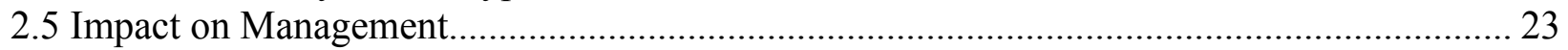

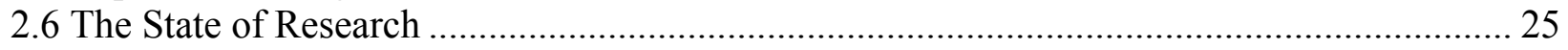

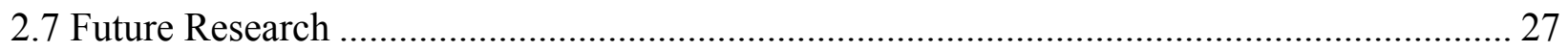

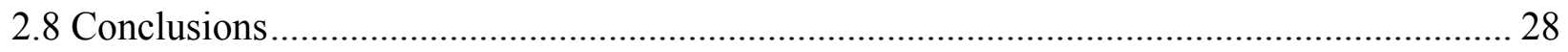

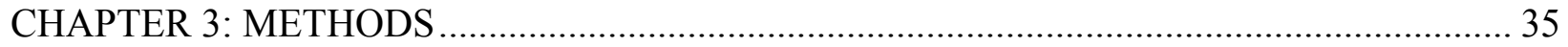

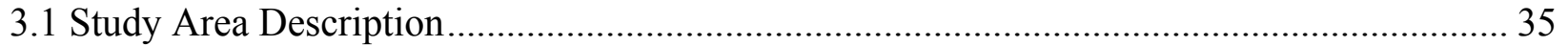

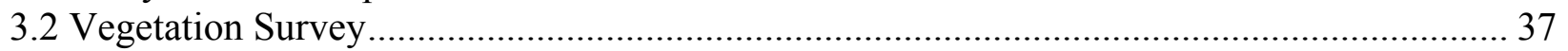

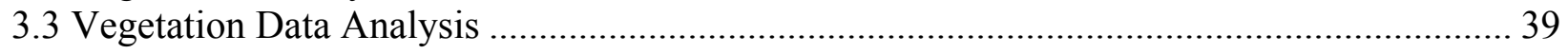

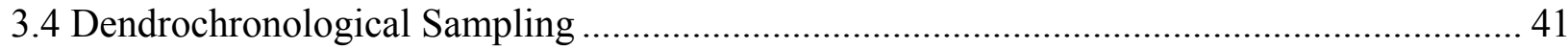

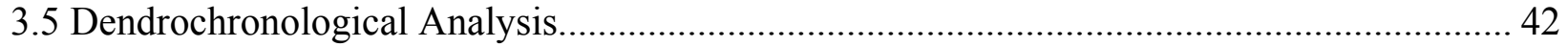

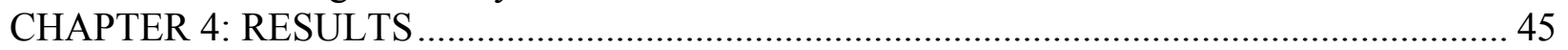

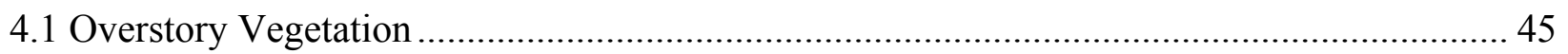

4.1.1 Overstory Structure and Composition ..................................................................... 45

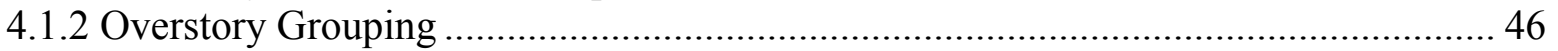

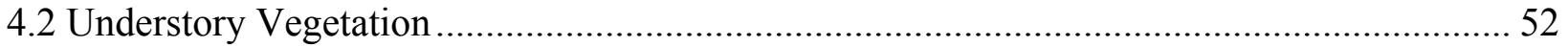

4.2.1 Understory Structure and Composition ...................................................................... 52

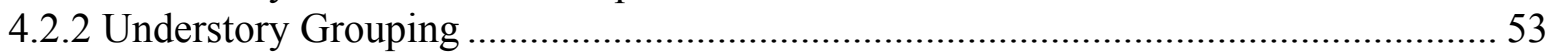

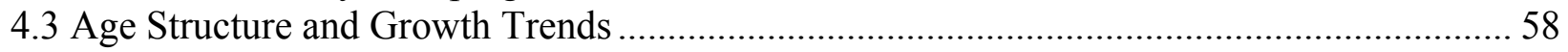

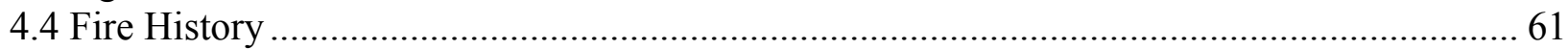

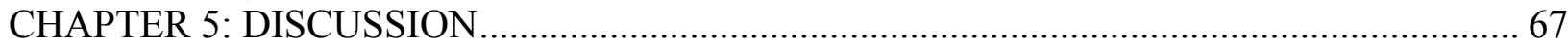

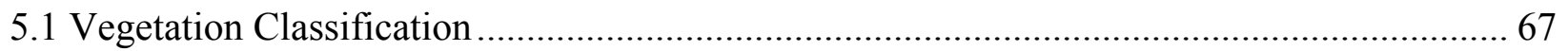

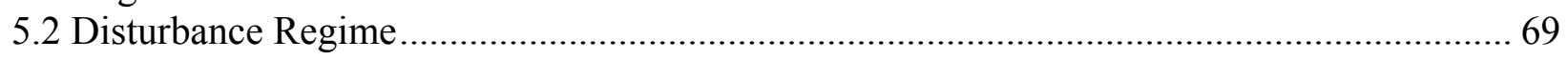

5.3 Management Suggestions ………………………..................................................... 72

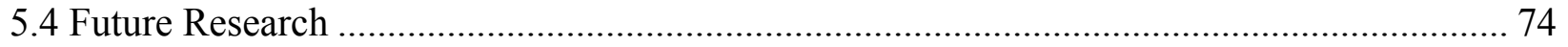

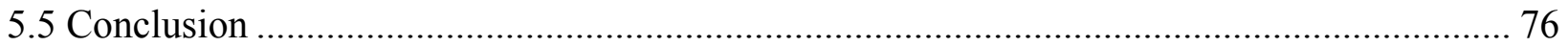

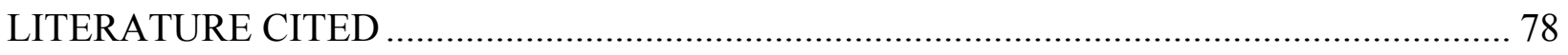


CURRICULUM VITAE. 


\section{LIST OF TABLES}

Table 1: Summary of the fire history studies conducted in the Central Hardwood Forests......... 33

Table 2: Databases searched for fire history literature with internet addresses and search word(s)

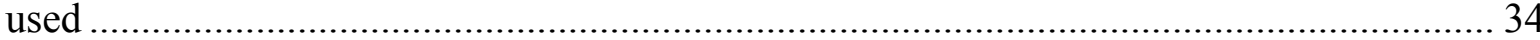

Table 3: Species composition and canopy position of trees sampled for age structure.............. 41

Table 4: Overstory species present in the rimrock forest with descriptive variables. ................. 50

Table 5: Understory species present in the sample transects with descriptive variables............. 55

Table 6: Summary of fire information for both sites combined .......................................... 65

Table 7: Fire interval analysis for the Fern Creek site using a liberal criterion (at least 1 tree

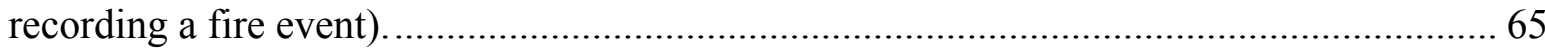

Table 8: Fire interval analysis for the Short Creek site using liberal (at least 1 tree recording a fire event) and conservative (at least 2 trees recording a fire event) criteria..................... 66

Table 9: Fire interval analysis for all sites using liberal (at least 1 tree recording a fire event) and conservative (at least 2 trees recording a fire event) criteria. ....................................... 66 


\section{LIST OF FIGURES}

Figure 1: Photo of the Nuttalburg tipple below the present day study site................................... 7

Figure 2: Braun's (1950) vegetation regions that comprise the Central Hardwood Forests ........ 13

Figure 3: Fire history study locations of the Central Hardwood Region ...................................... 18

Figure 4: Location of sample transects and cross sections. ....................................................... 36

Figure 5: Photo of the sandstone cliffs that compose the Endless Wall ..................................... 37

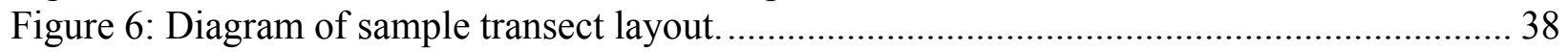

Figure 7: Number of stems by species for each section of sample transects.............................. 48

Figure 8: Diameter distribution by species from 22 sample transects along the "Endless Wall"

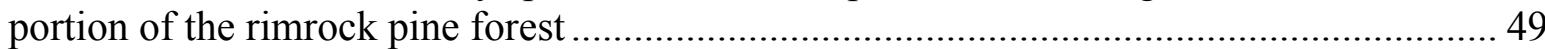

Figure 9: Cluster analysis of $8510 \times 6 \mathrm{~m}$ transect sections using overstory tree (DBH $>2.54 \mathrm{~cm})$ species IV as input data............................................................................................. 51

Figure 10: Number of understory stems by species for each plot and size class......................... 54

Figure 11: Percentage of shrub cover in understory plots by species for each plot location (based on distance from the cliff edge) and size class. ...............................................................5 56

Figure 12: Cluster analysis of 64 understory plots using understory woody vegetation $(\mathrm{DBH}<$

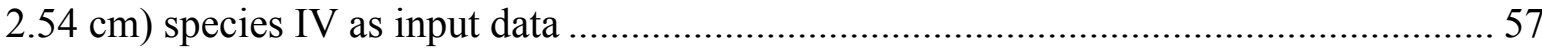

Figure 13: Age-diameter distribution of species sampled along the "Endless Wall" in New River Gorge National River, WV .................................................................................... 59

Figure 14: Master chronology for Pinus species $(\mathrm{N}=16)$ using three standardization methods... 59

Figure 15: Master chronology for Quercus species $(\mathrm{N}=10)$ using three standardization method 60 Figure 16: Master chronology for Acer rubrum ( $\mathrm{N}=7$ ) using three standardization methods...... 60

Figure 17: Fire scar chronology from 22 Virginia pines and 1 pitch pine cut from the "Endless Wall" in the northern section of New River Gorge National River, WV.

Figure 18: Fire return interval boxplots for Fern Creek, Short Creek, and both sites combined . 64 


\section{CHAPTER 1: INTRODUCTION}

\subsection{New River Gorge National River}

New River Gorge National River (NERI) was formed in 1978 for "the purpose of conserving and interpreting outstanding natural, scenic, and historic values and objects in and around the New River Gorge and preserving as a free-flowing stream an important segment of the New River in West Virginia for the benefit and enjoyment of present and future generations" (Public Law 95-625). With this mandate and subsequent legislation, the National Park Service (NPS) has protected and managed the cultural, recreational, and ecological resources located along the $85.3-\mathrm{km}$ stretch of the New River in southern West Virginia between the towns of Hinton and Fayetteville. There are 28,636 ha of land, spreading through Summers, Fayette, and Raleigh counties, within the park boundary. While the NPS owns $73 \%$ (20,828 ha) of this land, private landowners and companies control the remaining hectares zoned within the boundary.

The New River Gorge is a significant physical feature on the landscape of the southern Allegheny Plateau, reaching over $300 \mathrm{~m}$ in depth and $1.6 \mathrm{~km}$ in width. The northwestern flow of the New River cuts across the Appalachian Mountains allowing for a mix of northern and southern forest communities. Braun (1950) classified this area of the Allegheny Plateau as a mixed mesophytic hardwood forest. Grafton (1982) and Suiter (1995) documented the occurrence of several hundred species of plants native to West Virginia as well as many species rare to NERI. Currently, species of oak (Quercus spp.), yellow-poplar (Liriodendron tulipifera L.), red maple (Acer rubrum L.), eastern hemlock (Tsuga canadensis [L.] Carr.), and other mesic species predominate within the park. However, unique forest communities, such as the rimrock pine forest, exist throughout NERI. Several factors are responsible for the establishment and 
maintenance of the diversity at NERI, including past and present land use, disturbance regimes, differences in aspect and elevation, and a mosaic of soil types.

\subsection{Rimrock Pine Communities}

The rimrock pine communities are most common on the southern and southwestern aspects of the northern section of the gorge, occurring on shallow, xeric soils. In Brooks' (1910) description of the original forest of Fayette County, he stated that scattered clumps of pitch pine (Pinus rigida Mill.) and Virginia pine (Pinus virginiana Mill.) grew on dry ridges and along the sandstone outcrops. Vanderhorst (2002) classified these linear communities as Virginia pine forests with lesser amounts of pitch pine, black gum (Nyssa sylvatica Marsh.), sourwood (Oxydendrum arboreum [L.] DC), and oak species in the upper canopy. However, this description was based on an ocular estimation of species composition of the rimrock community rather than on sample plot data of the canopy. The Society of American Foresters (1980) list $P$. virginiana as a major species of the Virginia pine-oak (type 78) and Virginia pine (type 79) forest cover types. Also, Virginia pine is associated with chestnut oak (Quercus prinus L.; type 44), pitch pine (type 75), eastern redcedar (Juniperus virginiana L.; type 46), and several other forest cover types.

Carter and Snow (1990) describe Pinus virginiana as a small to medium-sized tree growing best on clay, loam, or sandy loam soils that are moderately well drained to well drained. The range of $P$. virginiana extends from the Piedmont north to the lower elevations $(760 \mathrm{~m})$ of the Appalachian Mountains in central Pennsylvania. It is also found along the Atlantic Coastal Plain and scattered into areas of Ohio, southern Indiana, and Tennessee. Pinus virginiana is a colonizer of old fields, burned areas, and other disturbed sites such as surface mines. Successful establishment of $P$. virginiana is dependent on the exposure of mineral soil (Carter and Snow 
1990). In a study conducted in the southern Appalachians, Barden (1976) found that all regeneration of $P$. virginiana over a 120 -year period was related to site disturbances such as fire and logging. Additionally, Sucoff (1961) found that areas disturbed by either logging or fire resulted in 2 to 4 times the rate of germination than undisturbed areas and four-fold the survival rate at 2 years post-germination. One issue of concern is the ability of $P$. virginiana to regenerate on the rimrock. It remains unknown how much $P$. virginiana regeneration is present in the community and how much is necessary to maintain the historic range of the rimrock forest type.

Burkman and Bechtold (1998) used Forest Health Monitoring and Forest Inventory and Analysis (FIA) data from the USDA Forest Service to determine whether or not Pinus virginiana was in decline. They found that $P$. virginiana experienced significant crown dieback and reduced crown density during the 1991-1997 period. In addition, the FIA data showed that mortality of the species was $48 \%$ and removals (i.e., timber) were $92 \%$ of the net annual growth for this same time period. They concluded that these reductions in health and population were due to the shade intolerance and short-lived nature of $P$. virginiana. Throughout the central and southern Appalachians, other ridgetop pine species such as pitch and Table Mountain (Pinus pungens Lamb.) pines are also in decline (Brose and Waldrop 2000, Waldrop et al. 2003). Researchers have identified several reasons for the decline including fire suppression (Harmon 1982, Abrams 1992, Delcourt and Delcourt 1997) and southern pine beetle (Dendroctonus frontalis; SPB) outbreaks (Zobel 1969). Similar to pitch and Table Mountain pines, regeneration of Virginia pine is thought to require fire or other disturbances to expose mineral soil and suppress deciduous competitors (Carter and Snow 1990). However, it is unclear if the rimrock 
pine communities are dependent on fire for regeneration or if they are an edaphic climax species on the rimrock sites.

It is known that older Virginia pine trees are susceptible to SPB attack. Veysey et al. (2003) investigated the relative suitability of Pinus virginiana and Pinus taeda L. (loblolly pine) as host species for southern pine beetle. They found that while P. virginiana was readily attacked and killed, it supported poor reproduction of SPB, suggesting that while outbreaks along the rimrock may occur in isolated locations, the spread of SPB is not a severe threat. Nonetheless, monitoring of NERI and surrounding NPS land should be ongoing in order to identify susceptible areas and protect valued habitats in the event of an outbreak. Other damaging agents that could affect $P$. virginiana communities include wind, snow, and ice damage, particularly in opened stands with shallow soils (Warrillow and Mou 1999). Additional threats to the health of the Virginia pine come from rodents, pine sawflies, and canker diseases (Fenton and Bond 1964).

\subsection{Land Use History}

\subsubsection{Pre-European Settlement}

Native American land use practices have had lasting impacts on the structure and composition of forest ecosystems in the eastern United States (Abrams 1992). Archeological evidence dating from 10,000 b.p. (before present) documents the presence of Native Americans along the New River through North Carolina, Virginia, and West Virginia. In 1965, the first official archeological survey of the upper New River uncovered 20 sites of Paleo-Indian habitation including several rock shelters (Johnson 1983). Marshall and Fuerst (1982) conducted an archeological survey of prehistoric cultures in the New River Gorge National River to aid in the collection and synthesis of cultural data and to predict the occurrence of archeological sites in 
the future. The authors found 248 new sites within the study area with some sites dating to 8,000 b.p. These sites were described as multi-activity rockshelters, base camps, villages, and burial mounds with varying degrees of usage. Seventy-six percent of sites were found in upland settings and were primarily rock overhangs or streamside sites. More recent evidence of Native American activity was documented by petroglyphs and pictographs representing human figures and animals. Rice (1985) mentioned the discovery of these drawings throughout West Virginia, citing Beards Fork in Fayette County as an example of the work of late prehistoric village farmers.

Other archeological investigations in the Bluestone Reservation have revealed 58 prehistoric Native American sites spanning 12,000 years (Maslowski 1982). Marwitt (1982) conducted test excavations of three sites at the Bluestone Reservation to determine the extent and nature of archeological deposits and to gather data and artifacts of prehistoric inhabitants. The excavations produced a collection of stone tools, specimens of worked bone, and shell and ceramic artifacts. Such evidence confirms the presence of Native Americans on the landscape of the southern Allegheny Plateau and the potential influence of pre-settlement land use on the forest ecosystem.

It is likely that Native American habitation in southern West Virginia was reduced significantly by the late 1600 's due to campaigns by the Iroquois to dominate the region as well as the introduction of foreign diseases. The late seventeenth century saw the influence of Dutch and British traders spread into the area. One of the first documented accounts of the New River by western explorers came from a British expedition headed by Thomas Batts and Robert Fallam in 1671 (Rice 1985). The group came across a river flowing northwest near the present day West Virginia-Virginia border and named it Wood's River (a.k.a. New River) in honor of early plant- 
trader, Abraham Wood. England used this journey to lay claim to the region and attempted to set up a direct fur trade with remaining tribes along the New River. However, a claim by French explorers that they had penetrated the Ohio Valley two years earlier sparked an international feud and possession of southern West Virginia was in dispute until after the French and Indian War.

The earliest and largest recorded land survey in Fayette County of the Commonwealth of Virginia occurred in 1785, granting 40,680 acres along the New River to Henry Banks. In subsequent years, land was granted to hundreds of individuals along prominent branches of the New River with the more fertile land being claimed first (Peters and Carden 1926). By the time West Virginia became an official state in 1863, settlers occupying land in Fayette County were clearing forests for agriculture, raising of livestock, and probing the surface of New River Gorge for salt and coal.

\subsubsection{Railroads, Coal, and Timber}

Prior to the development of the railroad industry in the New River Gorge, coal operators faced great challenges moving coal out of the region. The first coal mine in the region was opened in 1873 by Joesph L. Buery following the completion of the Chesapeake and Ohio $(\mathrm{C} \& \mathrm{O})$ Railroad. In the following decades, an extensive array of mines opened throughout the New River Gorge, becoming the dominant industry in southern West Virginia. Coal from the New River field was known internationally to be clean-burning, high-quality, and low-sulfur, making it highly suitable for metallurgic uses (Unrau 1996). By 1900, Fayette and Mercer counties had 8,287 coal employees and 1,845 associated manufacturing jobs (Unrau 1996).

One prominent coal operator, John Nuttall, became the second to ship coal out of the gorge in 1873. The Nuttallburg Coal Company consisted of two mine sites located on Keeneys Creek and Short Creek. Seventeen two-family dwellings, 80 one-family residences, 80 coke 
ovens, and 4 two-car monitors were erected within the first two years of operation. The Nuttalburg mine, located on the slope of the gorge just below the Endless Wall, had a scalehouse, scales, a headhouse, a blacksmith shop, a carpenter shop, a slate dump, and a tipple extending up the slope of the gorge (Fig. 1). To access Nuttall's Keeneys Creek mine and his extensive landholdings on the plateau, he constructed a four-mile railroad subdivision connecting to the C\&O railroad. By 1880 , the Nuttallburg Coal Company was the largest producer of coal in the New River Gorge (Unrau 1996).

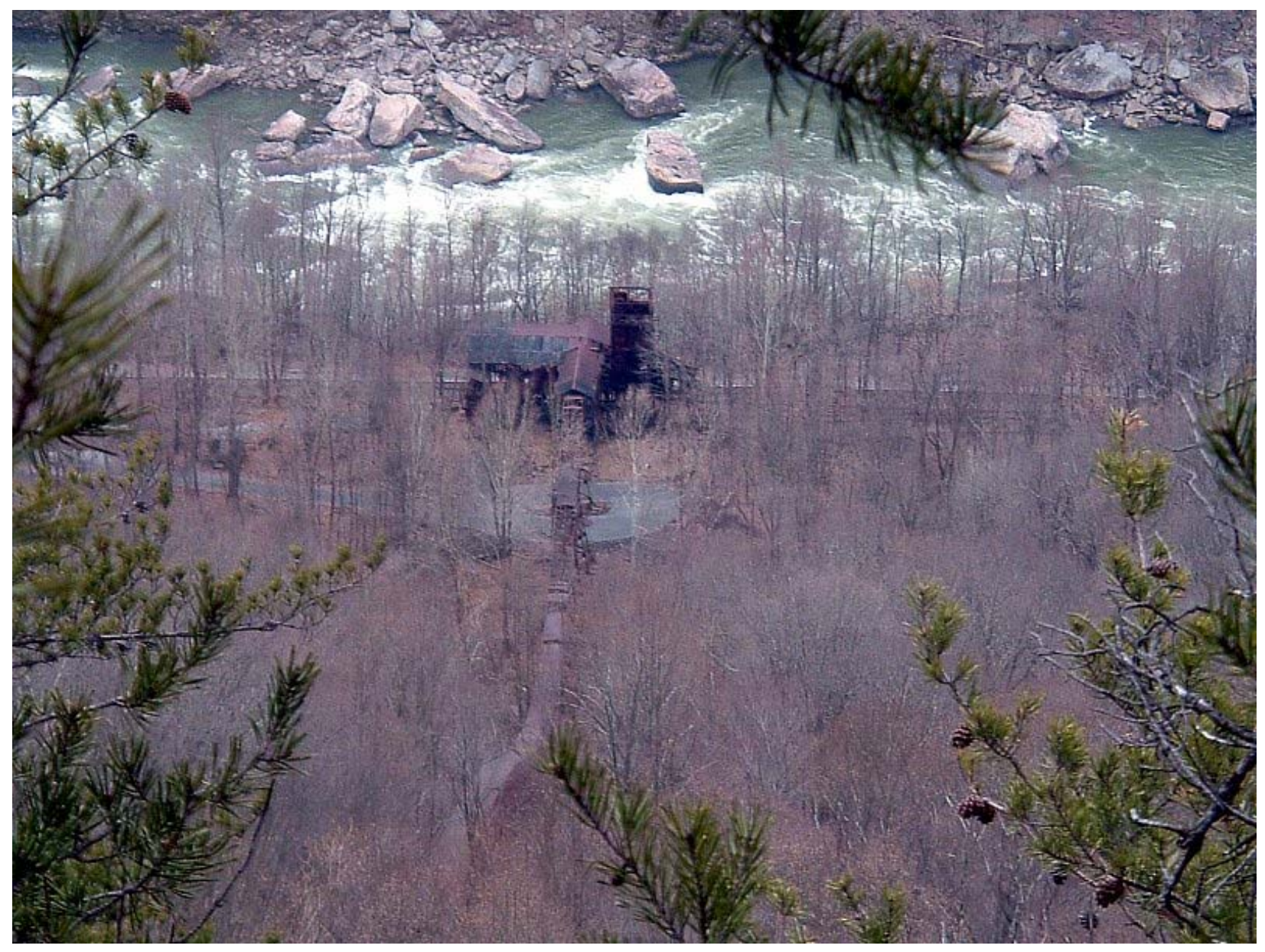

Figure 1: Photo of the Nuttalburg tipple below the present day study site.

To support the industry, coal companies purchased additional acreage to meet the timber requirements of the mines and mining towns. For example, Nuttall acquired $5.6 \mathrm{~km}$ of riverfront 
property as well as a 10,000-ha estate on the plateau to meet his timber needs. Brooks (1910) noted that the commercial timber industry in Fayette County did not begin until 1885 . The land surrounding the approximately 150 mines in the New River Gorge was harvested by the early 1900 s, leaving about 21,450 ha of virgin forests in the county. While $90 \%$ of the county grew back into forestland, the woodlot forests owned by the coal and timber industries became dominated by less valuable timber species such as black gum, American beech (Fagus grandifolia Ehrh.), birch (Betula spp.), sugar maple (Acer saccharum Marsh.), and red maple (Brooks 1910).

The mine at Nuttallburg was sold several times through the first half of the $20^{\text {th }}$ century, and continued to produce coal until it finally closed in 1958. The town of Nuttallburg became a ghost town following the closing of the mine and the remnant mine structures became slowly covered by kudzu vines (Maddex 1992). The coal industry operated within the New River Gorge into the 1960 s, producing a significant portion of the total coal for the entire country for many years. Though timber cutting and coal mining are no longer allowed within park boundaries, the impact on the landscape of decades of extraction remains, particularly through changes in species composition and forest structure.

\subsection{The Present Study}

In 2003, the NPS hosted a workshop to identify significant forest issues, resources, and processes occurring within the park (National Park Service 2003b). Several forest communities of concern were identified by the panel of scientists and resource managers. One such community, the rimrock pine forest lining the rim of the gorge, was chosen due to the importance of the community to wildlife and recreation. The rimrock pines were also thought to be a historically significant feature of the northern section of the gorge as evidenced by historic 
photographs from the 1940s and 1950s. The panel suggested an investigation be conducted to better understand the establishment and maintenance of the rimrock pine forest.

The workshop was followed by the Natural Resource Assessment for New River Gorge National River (Mahan 2004). In this report, Mahan provided information on the current status and significance of, threats to, and gaps in knowledge about the natural resources at NERI. The rimrock pine community was identified again as a valued resource that may be in decline due to lack of disturbance. Vanderhorst (2001) reported that plant communities including the rimrock pines, old fields, seeps, and herbaceous wetlands occupy approximately $1 \%$ of the land area at NERI. Despite the small area forested by rimrock communities they have been deemed valuable by the NPS and warrant further research.

The Natural Resource Assessment has served as a primer for the development of a new General Management Plan (GMP) for the park. Suggested management recommendations for the rimrock pine community include forest health monitoring, dendrochronological analysis, and forest restoration through the use of prescribed burning. The GMP is presently under revision; however, management of niche communities will require research before implementation of management and restoration activities. Thus, both qualitative and quantitative descriptions of the rimrock are crucial to the preservation of this resource for the use of wildlife and the enjoyment of future generations of park visitors.

The present study was designed to meet the following research objectives of the NPS. Objective 1. An inventory and description of all strata of vegetation was conducted to evaluate the current stand condition including species composition, stand structure, vigor, and potential for regeneration. Understanding the current condition of the rimrock community is 
necessary to establish whether or not the ecosystem is in the desired state which will affect future management decisions regarding these valued habitat and recreation areas.

Objective 2. A dendroecological analysis of Virginia pine, as well as other dominant species present in the rimrock community, was used to determine the age structure, growth trends, and disturbance regime (i.e., fire history) of the forest. This investigation required the collection of increment cores from live canopy trees and cross sections from fire-scarred Virginia pines.

Objective 3. An array of historic evidence was collected and reviewed to aid in the interpretation of the current condition of the rimrock forest and to determine the historic range of the Virginia pine forest type. Materials such as past land use records, mining activities, and historic maps and photographs were essential in the development of a clearer understanding of the establishment and maintenance of the rimrock community. 


\section{CHAPTER 2: FIRE HISTORY IN THE CENTRAL HARDWOOD FORESTS}

\subsection{Introduction}

After decades of fire suppression in the United States, agencies such as the USDA Forest Service and the National Park Service have recognized the role of fire in the development and maintenance of our forestlands. Much of the current research in the U.S. has focused on western (Agee 1993) and southeastern (Van Lear 1984, Wade et al. 2000) forest ecosystems. Fire research activities have concentrated in these regions because of the high fire frequency and extent, damage to significant resources (e.g., timber, residential areas, and wildlife habitat), and availability of evidence [i.e., fire-scarred trees and stand-age data; (Agee 1993, Pyne et al. 1996)]. Fire regimes in eastern deciduous forests have not been studied as extensively, yet, the importance of reintroducing fire to the eastern landscape has been discussed (Abrams 1992, Brose et al. 2001, Schuler and McClain 2003) and is occurring in many locations (Van Lear 1984, Brose and Waldrop 2000, Shifley and Brookshire 2000, Ruffner and Groninger 2006). In particular, some have emphasized the role of fire in the regeneration of mixed-oak forests (Abrams 2000, Brose et al. 2001, Elliott et al. 2004) while others have studied fire effects on eastern pine ecosystems (Sutherland et al. 1993, Brose et al. 2002).

Like much of the eastern United States, the role of fire in the Central Hardwood Forests is not clearly understood. A regime of frequent, low-intensity fires has been suggested for the majority of the region (Pyne 1982, Lorimer 1985, Abrams 1992, Brose et al. 2001). However, the management of the different vegetation types present in the CHR requires specific knowledge of fire regimes in order to achieve forest regeneration and ecosystem restoration objectives. The goals of this chapter are to: 1) synthesize available fire-scar data in order to characterize the fire regime and its variability in this region, 2) address management 
implications, 3) discuss why there is a dearth of fire history research, and 4) help focus future research of fire history in the region.

In this review, I will focus on dendrochronological (tree-ring) evidence of fire. It is important to understand the characteristics of past fire regimes (e.g., fire frequency) if we are to determine whether or not fire is an integral part of the establishment and maintenance of forest ecosystems (Stokes 1980). While other methods of investigation (e.g., monitoring prescribed burning) have been useful in learning the effects of fire on current forest conditions (e.g., Brose and Van Lear 2004, Elliott et al. 2004), restoring a historic fire regime will require accurately dated evidence of past fire frequency, intensity, seasonality, and extent. An analysis of fire scars is not without its drawbacks. Much of the evidence of historic fires has been destroyed through the extensive land clearing and logging of the $19^{\text {th }}$ and $20^{\text {th }}$ centuries. Yet, understanding the effects of fire in our forests will require more than evidence of the presence of fire alone (Agee 1993). We must investigate how fire has behaved over time and space to gain a better understanding of the role of fire in the CHF, and dendrochronology may be one of the best tools to accomplish this goal.

\subsection{Central Hardwood Region}

The Central Hardwood Region (CHR) encompasses the largest contiguous forest on Earth that is composed primarily of deciduous tree species. Hicks (1998) broadly defines the CHR as the area south of the beech-maple forests, east of the Great Plains, and northwest of the southern pine forests. It extends from New York to Georgia and from Maryland to Missouri covering approximately $609,000 \mathrm{~km}^{2}$.

Four major vegetation types are represented in the region including the Oak-Chestnut, Oak-Hickory, Western Mesophytic, and Mixed Mesophytic (see Braun 1950). Though 


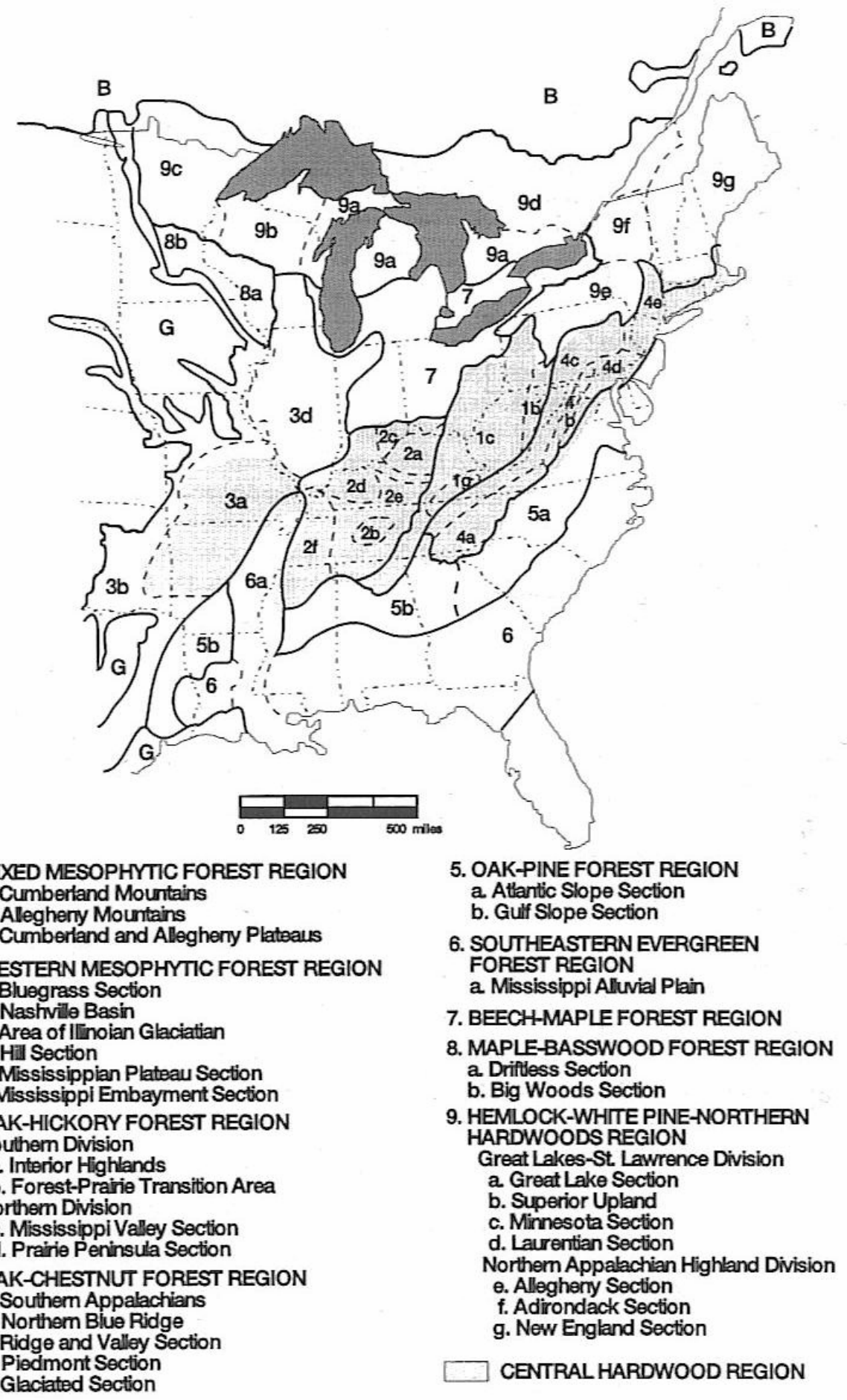

Figure 2: Braun's (1950) vegetation regions that comprise the Central Hardwood Forests (reproduced from Hicks 1998). 
deciduous angiosperms predominate in the Central Hardwood Forests (CHF), a variety of gymnosperms, such as Virginia, shortleaf (Pinus echinata Mill.), eastern white (Pinus strobus L.), and pitch pines, as well as eastern hemlock and species of spruce (Picea spp.), are locally important across the region. The majority of the CHF is located within the highland regions of the Ridge and Valley, Blue Ridge, Appalachian Plateau, and Ozark/Ouachita provinces with lowland areas situated in the Interior Low Plateau and New England provinces (see Fenneman 1938). The dominant climate of the region is classified as humid and continental. Total annual precipitation ranges from 100-127 cm with locally lower and higher amounts recorded in mountainous sections (National Oceanic and Atmospheric Administration 2005). Primary soil orders for the CHF include Inceptisols, Ultisols, and Alfisols with an array of modifiers (Natural Resources Conservation Service 2005). For a complete treatment of the ecology and management of Central Hardwood Forests consult Hicks (1998).

The current forests of the eastern United States are the product of climate, soils, and a suite of disturbance factors such as land clearing for agriculture, logging, insect and disease outbreaks, and fires. Prior to European settlement, Native American land-use was thought to significantly alter forests in the eastern United States (Abrams 1992, Denevan 1992, Hicks 2000). Native Americans used fire to clear land for subsistence agriculture, drive game, create browse for game species, and create a walkable forest clear of underbrush (Pyne 1982). However, it has been difficult to determine the extent and frequency of Native burning in this region because much of the evidence supporting Native American use of fire has been from anecdotal reports of surveyors, explorers, and Native American elders. Paleoecological studies have provided the best evidence of the historic fire regime in the CHF linking pollen abundance of fire-adapted species (e.g., Quercus spp.) with the presence of charcoal in pond and bog core 
samples (Watts 1980, Davis 1985, Delcourt and Delcourt 1997). While such evidence is valuable in documenting general trends in fire frequency on the historic landscape, charcoal records have low temporal resolution and must rely on charcoal particle size to infer fire extent. A more precise method of dating fire events is dendrochronology or tree-ring analysis (Stokes 1980). The application of dendrochronology to the analysis of fire scars has allowed researchers to assess the frequency (e.g., Grissino-Mayer and Swetnam 1997), extent (e.g., Heyerdahl et al. 2001), and seasonality of fire events (e.g., Grissino-Mayer and Swetnam 2000) with accuracy not possible in other methods of investigation.

In contrast to the Native American uses of fire, the impact of European settlement on the CHF landscape is better understood. Settlers utilized fire to clear land for farming and cut trees for fuel and building materials. In the mid-1800's, the iron industry began to develop in the region. Firing stone furnaces required repeated clearing large patches of forestland on very short rotations and burning the wood to produce charcoal (Clatterbuck 1991, Hicks 2000). Luther (1977) estimated that the pig-iron industry of the highland rim of middle Tennessee required approximately 97,000 hectares of timber to support 11 furnaces. In the late-1800's and early1900 's, the timber industry followed the iron industry cutting much of the remaining forests. Similar land use changes were common across Pennsylvania, Maryland, and West Virginia.

\subsection{Fire History Terminology}

In reviewing the studies of fire history in the Central Hardwood Forest, several key characteristics of fire regimes should be clarified in order to correctly interpret existing studies. The level of analysis has become more complex as the science of tree-ring dating and its application to studying past fire regimes has developed. Initially, researchers calculated simple 
mean fire intervals. Now, more precise descriptions of fire regimes are determined with new standards for sampling designs, statistical procedures, and data on seasonality and fire extent.

Though fire is considered to have been a ubiquitous disturbance in the CHF, local disturbances may be altered by climate, topography, structure and composition of the forest, and humans (White and Jentsch 2001). It is important to consider the generality of fire regimes and their applicability to other regions because the description of a fire regime may change depending at which spatial and temporal scale they are measured (Morgan et al. 2001). For example, a fire frequency measure can be estimated for one point in a stand (i.e., point fire return interval) or for the forest as a whole [(i.e., composite fire return interval; (Arno and Peterson 1983)]. Knowing the vegetation type, size of the study area, time period, sample size, and whether or not fire scar dates have been crossdated is critical in the interpretation of fire intervals. The following list of definitions commonly used in fire scar analysis literature were adapted from Romme (1980):

Fire Interval (a.k.a. Fire Free Interval or Fire Return Interval)- the number of years between two successive fires that have been recorded (i.e., produced a fire scar) by one or more trees.

Mean Fire Interval (a.k.a. Mean Fire Free Interval, Mean Fire Return Interval, or MFI)the arithmetic average of all fire intervals in a defined study area of a defined period of time; also, Weibull probability distributions are used to determine median and modal fire intervals.

Fire Intensity- a relative term used to describe the magnitude of ecological effects of fire (e.g., a fire that results in low mortality is referred to as a low-intensity fire while a stand- 
replacing fire produces high mortality); also, percent of scarred trees has been used to describe intensity.

Fire extent- the area of an individual burn (in hectares or square kilometers); while not often discussed in fire history literature in the eastern United States, several authors infer fire extent from the number and location of fire-scarred trees of a given fire year.

Seasonality- the time of year when a fire occurred; position of the fire scar within the tree ring is typically used to determine seasonality and fires are typically classified as earlygrowing season, late-growing season, and dormant season fires.

Crossdating- used to establish synchroneity between the ring patterns of one sample with another; crossdating allows fire scars to be absolutely dated by correcting individual specimens with a master chronology.

\subsection{Fire Histories by Forest Type}

The first goal of this paper is to review available fire history research conducted in the CHR. Several databases were searched to compile a list of references to be reviewed (Table 2). In the past, forest types have been used to summarize fire regimes due to the similarity of vegetation and environmental effects of fire on these communities (Abrams 1992, Agee 1993, Brown and Smith 2000). I have chosen to organize the data by Braun's (1950) forest regions: Oak-Chestnut, Oak-Hickory, Western Mesophytic, and Mixed Mesophytic. Study locations are displayed in Figure 3 and Table 1 (located at end of chapter) provides a summary of the fire history data collected for the review. For each study I have reported the vegetation region, subregion, species, fire interval, chronology dates, frequency computation method, size of study area, number of fires or scars, sample size, type of data, and whether or not the authors crossdated specimens and addressed fire extent, seasonality, and intensity. 


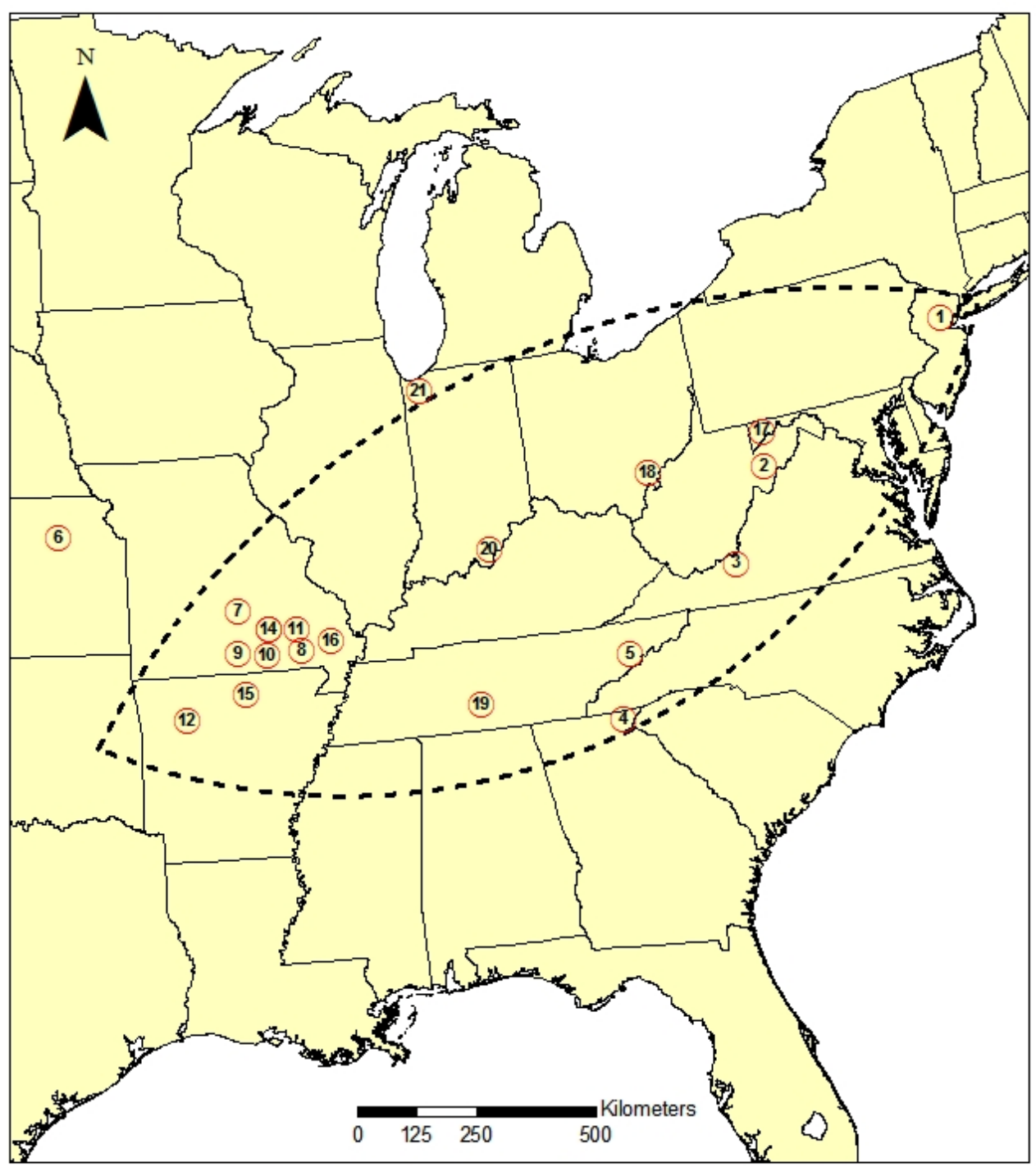

1. Buell et al. 1954

2. Schuler \& McClain 2003

12. Guyette \& Spetich 2003

3. Sutherland et al. 1993

13. Guyette \& Dey 1997

4. Brose et al. 2002

14. Guyette \& Stambaugh 2002

5. Harmon 1982

15. Jenkins et al. 1997

6. Abrams 1985

7. Cutter \& Guyette 1994

16. Stambaugh et al. 2005

8. Dey et al. 2004

17. Shumway et. al 2001

18. Sutherland 1991

9. Guyette \& Cutter 1991

10. Guyette \& McGinnes 1982

19. Guyette \& Stambaugh 2004

11. Guyette \& Cutter 1997

20. Guyette et al. 2003

21. Henderson \& Long 1985

Figure 3: Fire history study locations (red circles) of the Central Hardwood Region (dashed line). 
In the Oak-Chestnut forest type that extends along the Appalachian Mountains, researchers have constructed fire history chronologies for Quercus (oak) and Pinus (pine) species. Buell (1954) dated an old-growth white oak (Quercus alba L.) in central New Jersey that recorded 6 fires between 1611 and 1711 with a fire interval of 14 years (calculated by author based on fire dates). Though this represented one of the first published examinations of fire history using tree rings in the east, these data are not replicated and must be interpreted cautiously. More recently, Schuler and McClain (2003) seized the opportunity to collect red oak (Quercus rubra L.) cross sections following an illegal timber cut on land owned by The Nature Conservancy in the Ridge and Valley province. The authors developed a 156-year chronology with fire intervals ranging from 7 to 32 years (MFI $=15.5$ years). However, the limited sample area (0.6 ha) and xeric site conditions make generalizations to other sites in the Oak-Chestnut forest type tenuous.

While the genus Pinus is less abundant in the Oak-Chestnut forest type, it is locally significant on ridges, rock outcrops, and south-facing aspects. Sutherland et al. (1993) researched the linkage between fire exclusion on Brush Mountain, VA and recent regeneration failures of Table Mountain pine (Pinus pungens Lamb.). They found mean fire intervals (MFIs) of 9 to 11 years prior to 1944 with few pines established after 1950. Other studies using pine species in the southern Appalachians have indicated MFIs of 12.7 (Harmon 1982) and 16.7 years (Brose et al. 2002). Finally, Lafon and colleagues (2005) investigated the relationship between climate and the contemporary fire regime (1970-2003) on federal lands located in the Ridge and Valley province. The primary objective of the study was not to determine fire return intervals, rather they focused on size, intensity, and seasonality of fire events. They found that that majority of fires occurring in this region were small acreage, low-intensity fires burning in the 
spring and fall (dry seasons) and that these fires were ignited by humans most of the time. The authors are continuing their investigation of fire regimes in this region using fire scars on Table Mountain, pitch, and Virginia pine stands (personal communication). Though studies located in the oak-pine interface of the Oak-Chestnut community do not represent the forest type as a whole, this research has provided valuable data for managing stands on dry, southern aspects.

The Oak-Hickory forests of Interior Highlands of Arkansas and Missouri have been the most intensely studied region of the CHF. Researchers have constructed fire history chronologies using shortleaf pine, post oak (Quercus stellata Wang.) and eastern redcedar. Guyette and Cutter (1991) utilized all three species to create a fire chronology with MFIs of 4.3 years during Native American habitation (1710-1810) and 6.4 years following the decline of tribal warfare (1811-1990). Similarly, fire intervals differed when chronologies were broken down into periods of human history and land use at other sites located in the Interior Highlands. Prior to European settlement, MFIs of 2.8 to 13 years were calculated for nearby study sites (Guyette and Cutter 1997, Guyette and Dey 1997, Guyette and Spetich 2003, Dey et al. 2004, Stambaugh et al. 2005). Following European settlement, Guyette and McGinnes (1982) and Cutter and Guyette (1994) found an increase in the MFI from $\sim 3$ years to $\sim 24$ years. The studies reviewed above highlight the importance of land use and human habitation patterns on fire regime characteristics in the Oak-Hickory forest type.

However, not all studies in the Oak-Hickory forests have focused on the effect of humans. Jenkins et al. (1997) found a MFI of 5.7 years in an oak-pine savanna-glade-woodland and noted that the percentage of fire-scarred trees was positively correlated with elevation $(\mathrm{r}=$ $0.83, \mathrm{p}<0.001, \mathrm{n}=18$ ). These results confirmed the hypothesis that fire intensity would increase as the fire moved upslope. Other studies conducted outside the typical range of the 
Oak-Hickory forest type have explored the role of fire in oak communities. Henderson and Long (1984) investigated two black oak sites on the shore of Lake Michigan in Indiana and found fire intervals of 5.2 and 11.1 years. They attributed current differences in stand structure between the two sites to differences in fire frequency.

In the Mixed-Mesophytic forests of the Allegheny Mountains, Shumway and others (2001) examined 20 oak cross sections ( $\sim 325$ ha) obtained from a previous shelterwood cut to document the fire history and associated ecological changes in an old-growth forest in western Maryland. They found a MFI of 7.6 years from 1615-1958 and increased recruitment of shade tolerant species following fire suppression in 1930. Such evidence supports the hypothesis that periodic fire played a significant role in the historical development and perpetuation of oak in this region. In an even-aged, second-growth oak stand in southern Ohio, Sutherland (1997) analyzed 14 cross sections to determine the frequency and seasonality of fire following EuroAmerican settlement. The author developed a fire chronology that revealed mostly dormant season fires (69\%) occurring every 3.6 years (1856-1995) and concluded that ignitions were primarily human-caused because of the area had been extensively cleared for agriculture and the iron industry. Additionally, shorter fire return intervals documented prior to the implementation of fire suppression would have favored the continued dominance of oak species.

On a different note, Guyette and Stambaugh (2004) researched the biological and statistical characteristics of fire-scarring of post oak along the Highland Rim, Tennessee to aid in the prediction of the effects of prescribed fire on trees and in the historical interpretation of past fire occurrences. They found a MFI of 7.7 years (1850-1950) and concluded that post oak were more likely to be scarred and survive when they were small diameter and had slow radial growth. Also, this study highlights the challenges of reconstructing fire histories from fire scars because 
of the danger of misinterpreting wounding events when charcoal is not present. Falsely interpreting a wounding event may misrepresent the historic fire regime and lead to incorrect management of prescribed burning programs.

While other researchers have documented fire as a frequent disturbance of the CHF, the data presented in these studies was not sufficient to establish key temporal and spatial characteristics of the fire regime. Typically, these studies focused on other ecological applications of tree-ring data such as the role of historic fires on forest stand dynamics. For example, Abrams (1995) investigated the disturbance history and successional dynamics of a Quercus alba - Castanea dentata Marsh. - Carya spp. - Pinus strobus forest in southern West Virginia. The radial growth chronologies of these species showed regular release events every 20-30 years. The author hypothesized that these release events, and the continued dominance of oak and pine in the stand until the era of fire suppression, were caused by small-scale, periodic fires. Similarly, Soucy et al. (2005) researched the establishment and development of oak forests in the Ozark Mountains of Arkansas. Using tree-rings and fire-scar analysis, they determined that forests established following timber and fire events in the 1900's. Again, the advent of fire suppression changed the succession dynamics of the forests and shade tolerant, fire-intolerant species began replacing oak in the understory. The authors suggested that prescribed fire may be an important management tool to aid in the regeneration of oak forests in this region.

In summary, mean fire return intervals range from 2 to 20 years for the Central Hardwood Forests. There are variations in the fire intervals that may be dependent on local vegetation composition, topography, and climate. For instance, Schuler and McClain (2003) found a Weibull median probability interval of 14.8 years in the Oak-Chestnut forests of the Ridge and Valley while Guyette and Stambaugh (2002) established a 3.75-year Weibull interval 
for the Oak-Hickory forest of the Interior Highlands. Despite our current knowledge of fire regimes in the $\mathrm{CHF}$, it is uncertain if fire behaved uniformly across the landscape because much of the existing research on fire regimes has been concentrated in small pockets of the region, was limited in temporal scale, and complicated by human influence (e.g., changes in land use).

\subsection{Impact on Management}

The era of fire suppression in the eastern United States has had lasting impacts on the structure and composition of the forests (Brose et al. 2001). As fire management on public and private lands becomes more active, an understanding the historic and modern trends in the fire regimes of the Central Hardwood Region is needed (Yaussy 2000). The general consensus on the role of fire in the CHF has led forest managers to implement prescribed burning programs on federal and state lands without a thorough understanding of the fire regime including frequency, extent, intensity, and seasonality. Then, given our current knowledge of the fire regimes of the Central Hardwood Forests, how has the fire history data affected forest management practices?

In some areas of the CHR, management may have proceeded ahead of science.

Prescribed burning programs have been approved and implemented prior to an understanding of the past fire regime. Such actions may have resulted from federal mandates, public opinion, or the lack of adequate information. Regardless, these programs may be ignoring key aspects of the past fire regime that helped establish and maintain present forest conditions. For example, in oak forests, burning in the wrong season or when advanced seedlings are too small may not promote regeneration of oak species because the fire did not adequately prepare the seedbed for germination and reduce competition from shade-tolerant, fire-intolerant species (Lorimer 1985, Van Lear and Watt 1993). Knowledge of the seasonality of historic fires can help managers schedule prescribed burns during the season when natural and/or anthropogenic wildfires burned 
in the past and aid them in achieving management objectives. However, determining the seasonality of the historic fire regime can be difficult due to different species' response to injury (Hengst and Dawson 1994), the effects of cutting and burning (Guyette and Spetich 2003), and the influence of changing climate over time (Grissino-Mayer and Swetnam 2000).

In other areas of the CHR, application of fire regime data has been successful. For instance, the Missouri Ozark Forest Ecosystem Project (MOFEP) has been compiling information and designing studies to address land use and disturbance history along with an array of other ecosystem processes (Shifley and Brookshire 2000). Fire history studies (e.g., Guyette and Dey 1997, Guyette and Stambaugh 2002, Dey et al. 2004) have established fire intervals for the region and provided needed data to monitor the effects of prescribed burning and natural fires on the ecosystem. Other federal and state lands have not been able to fund projects of such magnitude and rely upon the best available information. Historic fire reports and silvical characteristics may indicate the past presence of fire; however, accurate data of fire regimes is still lacking.

Currently, public land managers are using prescribed burns to achieve resource management objectives such as fuel load reduction and regeneration of oak species. Smoke management issues, presence of threatened and endangered species, and protection from damage to adjacent private property often determine the timing and size of burn areas. For example, the New River Gorge National River proposed in their Wildland Fire Management Plan (2005) to utilize prescribed fire to reduce fuel loads, maintain native vegetation, preserve the historic scene, and maintain fire-adapted ecosystems. The Fire Plan recognized the value of fire history data to establish and maintain forest ecosystems. However, the linear nature of the park and its proximity to towns and interstates may govern future burn prescriptions. Though managers must 
consider the social, political, and economic impacts of prescribed fire, it is essential that fire management plans actively seek data on local fire regimes and understand how fire can meet management goals prior to burning extensive areas.

Of course, the use of prescribed burns may be helpful in determining the effects of fire on forest regeneration, species composition, and other ecosystem processes. Researchers at the USDA Forest Service Southern Research Station, Coweeta Hydrologic Laboratory have conducted numerous studies investigating the effects of prescribed fire on hardwood survival in pine-oak forests, understory vegetation, nutrient cycling, and Table Mountain pine regeneration (Van Lear and Waldrop 1989, Brose et al. 2002, Elliott et al. 2004). These studies provide valuable information that allow researchers and managers to assess specific changes following prescribed fire, but they do not reveal characteristics of the historic fire regime. Therefore, the use of prescribed fire should be informed by an understanding of the frequency, extent, intensity, and seasonality of the past fire regime.

\subsection{The State of Research}

The study of fire regimes has been active throughout the $20^{\text {th }}$ century even during the time of fire suppression (Pyne et al. 1996); however, research has concentrated in the southeastern and western United States. Fire regimes of longleaf pine (Pinus palustris Mill.) of the southeast (Hermann 1993), ponderosa pine (Pinus Ponderosa Dougl.) forests of the Rocky Mountains (Veblen et al. 2000, Allen et al. 2002, Ehle and Baker 2003) and southwest (Swetnam 1990, Swetnam and Baisan 1996, Grissino-Mayer and Swetnam 1997), and the chaparral of the California coastline (Keeley 2002, Moritz 2003) have been studied in detail and results have had major implications for fire management. So why has less attention been given to the Central Hardwood Forests? Is there a lack of physical evidence (e.g., old-growth forests) due to past 
land use history? Does species longevity or how species record fire events in the eastern states play a role?

It has been suggested that a historic fire regime of frequent, low-intensity fires predominated in the CHR prior to the land-use practices of Euro-Americans in the late 1800's (Pyne 1982, Lorimer 1985, Abrams 1992, Brose et al. 2001). However, the research reviewed above shows substantial variation among the fire regimes of forests types in the CHF and many areas lack data. Differences in dominant tree species, land use history, and topography may have influenced fire regimes across the eastern U.S., so a single fire return interval will not be sufficient for the complex management requirements of public and private forests. Though the western states have an intense fire season nearly every year, large fires in the east have had significant impacts on forestland as well. For example, in southern West Virginia, the third most forested state, ten counties reported fires in 1986, 1987, and 1991. These counties averaged $3.39 \%$ to $32.74 \%$ of land area burned each year (Hicks and Mudrick 1993).

One impediment to studying fire history in the CHF may be the lack of physical evidence. In the late $19^{\text {th }}$ century and early $20^{\text {th }}$ century, the majority of the region was harvested for timber. Remaining refugia of old-growth stands remain but due to the ecological sensitivity of these areas, obtaining appropriate sample sizes of intact specimens may be difficult. Similar to the methods of Schuler and McClain (2003) and Shumway and others (2001), opportunistic sampling of lands disturbed by logging or other activities can provide valuable and, otherwise, unobtainable data. Species longevity may limit the ability of researchers to extend fire chronologies longer than two or three hundred years. However, species such as eastern hemlock, are reported to live almost 1000 years (Hough 1960). Additionally, identifying fire-scarred trees in central hardwoods may be difficult because of the avoidance of injury through constitutive 
protection and induced defenses (Smith and Sutherland 2001). Smith and Sutherland (1999) dissected chestnut and black (Quercus velutina Lam.) oaks present during two prescribed burns during the 1990's in southeastern Ohio and found that trees exposed to single fires did not have outward signs of scarring (e.g., charred bark and scorched wood).

\subsection{Future Research}

The Central Hardwood Region encompasses roughly $609,000 \mathrm{~km}^{2}$ of Oak-Chestnut, OakHickory, Mixed Mesophytic and Western Mesophytic forests in the eastern United States. Thirteen of the twenty-four fire history studies listed on Table 1 occurred in the Oak-Hickory forests. Of those thirteen, eleven studies were conducted in the highlands of Arkansas or Missouri, making it the most studied area in the CHR. While this is a significant step toward a better understanding of the role of fire in Oak-Hickory forest of the CHR, these data are not representative of the $\mathrm{CHF}$ as a whole.

In the remaining forest types, many studies have been conducted in unusual stands (Abrams 1985), have limited sample sizes (Buell et al. 1954), or insufficient sample area (Schuler and McClain 2003), making it difficult to generalize results to the region. Further research concentrated in representative stands is needed to confirm and broaden the applicability of past research to other areas of the CHF. Given the extent of the Mesophytic forests of the Mississippi and Allegheny Plateaus and the Oak-Chestnut forests of the Appalachian Mountains, considerable gaps in our understanding of the historic role of fire in the CHF still remain.

Old-growth forests of the region that have undergone little or no anthropogenic disturbance in the past centuries represent a unique opportunity for fire ecologist to investigate historic and contemporary fire regimes (Abrams et al. 1995). Stands of post oak in the Ozarks, white oak on the Allegheny Plateau, and Table Mountain pine in the Ridge and Valley may be 
our best recorders of past disturbances. Difficulty arises when these stands are located on private lands, for much of the CHF is owned by non-industrial private landowners. However, some of these forests exist on federal lands such as Monongahela National Forest, Great Smoky Mountains National Park, and Ozark National Scenic Riverways. Other potential study sites are located on state parks and forests, gamelands and conservation lands. While obtaining permission to sample on some public forests may be difficult, these are the areas that we will have the best chance to affect change in management prescriptions with the backing of sound scientific data.

The application of dendrochronology to fire history studies also has been useful in understanding the effects of fire on species and communities of special concern. Hessl and Spackman (1995) highlighted the importance of fire in the management of threatened and endangered plants [e.g., Peter's Mountain Mallow (Iliamna corei)] in the United States. Mahan (2004) emphasized the utility of tree-ring analysis to understand the development and maintenance of valued rimrock pine communities in New River Gorge National River, West Virginia. These unique communities may be very sensitive to even small changes in frequency and seasonality. Understanding the role of fire in the development and maintenance of herbaceous and understory woody vegetation of the CHR will require additional fire history research that describes spatial and temporal characteristics of fire regimes.

\subsection{Conclusions}

Central Hardwood Forests are the product of a long history of natural and anthropogenic disturbances including insect and disease epidemics, logging, agriculture, and burning. The influence of fire in the development and regeneration of the eastern forests is widely accepted. Yet, this acceptance of fire is not supported by quantitative data on frequency, extent, and 
variability of fire in the region. In this chapter, I have reviewed literature addressing fire history from a dendrochronological perspective. Mean fire intervals ranged from 2 to greater than 20 years across the CHF with fire history chronologies evidencing changes in fire regimes with land use across the past few centuries. While the papers presented here provide valuable knowledge of the characteristics of fire regimes in the eastern deciduous forests, these studies have concentrated in pockets of the region that may not be representative of the entire area. Future research is needed to describe the fire regimes of much of our federal, state, and private lands and to aid managers who are charged with the task of restoring and maintaining desired forest conditions. 


\begin{tabular}{|c|c|c|c|c|c|c|c|c|c|c|c|c|c|c|}
\hline $\begin{array}{l}\text { Forest } \\
\text { Region }\end{array}$ & Sub-region & $\begin{array}{c}\text { Study } \\
\text { Location }\end{array}$ & Species & $\begin{array}{c}\text { Fire } \\
\text { Interval } \\
\text { (years) }\end{array}$ & Chronology & $\begin{array}{c}\text { Interval } \\
\text { Method** }\end{array}$ & $\begin{array}{c}\text { Size of } \\
\text { Study } \\
\text { Area } \\
\end{array}$ & $\begin{array}{l}\text { Number of } \\
\text { Fire Scars }\end{array}$ & $\begin{array}{c}\text { Sample } \\
\text { Size }\end{array}$ & $\begin{array}{c}\begin{array}{c}\text { Cross- } \\
\text { dated? } \\
(\mathbf{Y} / \mathbf{N})^{* * *}\end{array} \\
\end{array}$ & $\begin{array}{c}\text { Fire } \\
\text { Extent? } \\
(\mathbf{Y} / \mathbf{N})\end{array}$ & $\begin{array}{c}\text { Seasonality? } \\
\text { (Y/N) }\end{array}$ & $\begin{array}{c}\text { Intensity/ } \\
\text { Severity? } \\
\text { (Y/N) }\end{array}$ & Reference \\
\hline \multirow{5}{*}{ 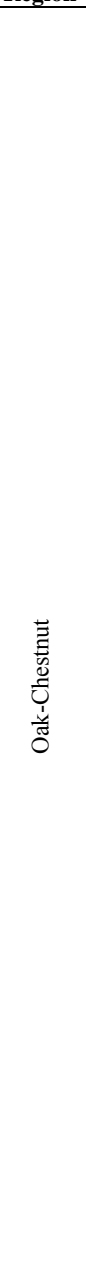 } & $\begin{array}{l}\text { Piedmont } \\
\text { Section }\end{array}$ & $\begin{array}{l}\text { Somerset } \\
\text { County, } \\
\text { New Jersey }\end{array}$ & Quercus alba & $14.0^{*}$ & $1641-1711$ & MFI & $\mathrm{N} / \mathrm{A}$ & 6 & 1 & $\mathrm{~N}$ & $\mathrm{~N}$ & $\mathrm{~N}$ & $\mathrm{~N}$ & $\begin{array}{l}\text { Buell et al. } \\
1954\end{array}$ \\
\hline & $\begin{array}{l}\text { Ridge and } \\
\text { Valley Section }\end{array}$ & $\begin{array}{l}\text { North Fork } \\
\text { Mountian, } \\
\text { Circelville, } \\
\text { West Virginia }\end{array}$ & Quercus rubra & $\begin{array}{l}15.5 \\
14.8\end{array}$ & $1846-2002$ & $\begin{array}{l}\text { MFI } \\
\text { WMedPI }\end{array}$ & 0.6 ha & 17 & 17 & Y & $\mathrm{N}$ & $\mathrm{N}$ & $\mathrm{Y}$ & $\begin{array}{l}\text { Schuler \& } \\
\text { McClain } \\
2003\end{array}$ \\
\hline & $\begin{array}{l}\text { Ridge and } \\
\text { Valley Section }\end{array}$ & $\begin{array}{l}\text { Brush } \\
\text { Mountain, } \\
\text { Montgomery } \\
\text { County, } \\
\text { Virginia }\end{array}$ & Pinus pungens & $9.0-11.0$ & 1765-1993 & MFI & N/A & 81 & 14 & Y & $\mathrm{N}$ & Y & $\mathrm{Y}$ & $\begin{array}{l}\text { Sutherland et } \\
\text { al. } 1993\end{array}$ \\
\hline & $\begin{array}{l}\text { Southern } \\
\text { Appalachian } \\
\text { Mountains }\end{array}$ & $\begin{array}{l}\text { Chattahoo- } \\
\text { chee National } \\
\text { Forest, } \\
\text { Northern } \\
\text { Georgia }\end{array}$ & Pinus pungens & $16.7^{*}$ & 1946-1996 & MFI & $\begin{array}{l}\text { 3, 10-ha } \\
\text { sites }\end{array}$ & 12 & 30 & $\mathrm{~N}$ & $\mathrm{~N}$ & $\mathrm{~N}$ & $\mathrm{~N}$ & $\begin{array}{l}\text { Brose et al. } \\
2002\end{array}$ \\
\hline & $\begin{array}{l}\text { Southern } \\
\text { Appalachian } \\
\text { Mountains }\end{array}$ & $\begin{array}{l}\text { Great Smoky } \\
\text { Mountains } \\
\text { National Park, } \\
\text { Tennessee/ } \\
\text { North } \\
\text { Carolina }\end{array}$ & Pinus spp. & 12.7 & 1856-1940 & MFI & $9100 \mathrm{ha}$ & 115 & 43 & $\mathrm{~N}$ & $\mathrm{Y}$ & $\mathrm{N}$ & $\mathrm{N}$ & Harmon 1982 \\
\hline
\end{tabular}




\begin{tabular}{|c|c|c|c|c|c|c|c|c|c|c|c|c|c|c|}
\hline \multirow{7}{*}{ 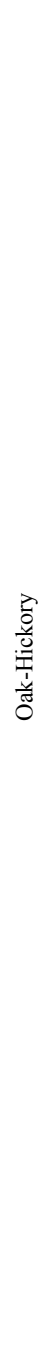 } & Sub-region & $\begin{array}{l}\text { Study } \\
\text { Location }\end{array}$ & Species & $\begin{array}{c}\text { Fire } \\
\text { Interval } \\
\text { (years) }\end{array}$ & Chronology & $\begin{array}{c}\text { Interval } \\
\text { Method** }\end{array}$ & $\begin{array}{l}\text { Size of } \\
\text { Study } \\
\text { Area }\end{array}$ & $\begin{array}{l}\text { Number of } \\
\text { Fire Scars }\end{array}$ & $\begin{array}{c}\text { Sample } \\
\text { Size }\end{array}$ & $\begin{array}{c}\text { Cross- } \\
\text { dated? } \\
(\mathbf{Y} / \mathbf{N})^{* * *}\end{array}$ & $\begin{array}{c}\text { Fire } \\
\text { Extent? } \\
\text { (Y/N) }\end{array}$ & $\begin{array}{c}\text { Seasonality? } \\
(\mathbf{Y} / \mathbf{N})\end{array}$ & $\begin{array}{l}\text { Intensity/ } \\
\text { Severity? } \\
\text { (Y/N) }\end{array}$ & Reference \\
\hline & $\begin{array}{l}\text { Forest-Prairie } \\
\text { Transition } \\
\text { Area }\end{array}$ & $\begin{array}{l}\text { Konza Prairie, } \\
\text { NE Kansas }\end{array}$ & $\begin{array}{l}\text { Quercus } \\
\text { macrocarpa, } \\
\text { Quercus } \\
\text { muehlenbergii }\end{array}$ & $11.2-19.7$ & $1862-1983$ & MFI & $\begin{array}{l}\text { 3,1-ha } \\
\text { sites }\end{array}$ & 47 & 19 & $\mathrm{~N}$ & $\mathrm{~N}$ & $\mathrm{~N}$ & $\mathrm{~N}$ & Abrams 1985 \\
\hline & $\begin{array}{l}\text { Interior } \\
\text { Highlands }\end{array}$ & $\begin{array}{l}\text { Mark Twain } \\
\text { National } \\
\text { Forest, } \\
\text { Missouri }\end{array}$ & Quercus stellata & $\begin{array}{l}2.8 \\
24\end{array}$ & $\begin{array}{l}1740-1850 \\
1851-1975\end{array}$ & MFI & $240 \mathrm{ha}$ & 84 & 24 & $\mathrm{Y}$ & $\mathrm{Y}$ & $\mathrm{N}$ & $\mathrm{Y}$ & $\begin{array}{l}\text { Cutter \& } \\
\text { Guyette } 1994\end{array}$ \\
\hline & $\begin{array}{l}\text { Interior } \\
\text { Highlands }\end{array}$ & $\begin{array}{l}\text { White Ranch } \\
\text { State Forest, } \\
\text { Missouri }\end{array}$ & Quercus stellata & $\begin{array}{l}3.7 \\
7.6 \\
3.6\end{array}$ & $\begin{array}{l}1705-1830 \\
1831-1960 \\
1961-1997\end{array}$ & MFI & $100 \mathrm{ha}$ & 135 & 35 & $\mathrm{Y}$ & $\mathrm{N}$ & $\mathrm{N}$ & $\mathrm{Y}$ & $\begin{array}{l}\text { Dey et al. } \\
2004\end{array}$ \\
\hline & $\begin{array}{l}\text { Interior } \\
\text { Highlands }\end{array}$ & $\begin{array}{l}\text { Caney } \\
\text { Mountain } \\
\text { Wildlife } \\
\text { Refuge, } \\
\text { Missouri }\end{array}$ & $\begin{array}{l}\text { Quercus } \\
\text { stellata, } \\
\text { Pinus echinata, } \\
\text { Juniperus } \\
\text { virginiana }\end{array}$ & $\begin{array}{l}4.3 \\
6.4\end{array}$ & $\begin{array}{l}1710-1810 \\
1810-1990\end{array}$ & MFI & $600 \mathrm{ha}$ & 175 & 43 & $\mathrm{Y}$ & $\mathrm{Y}$ & $\mathrm{N}$ & $\mathrm{Y}$ & $\begin{array}{l}\text { Guyette \& } \\
\text { Cutter } 1991\end{array}$ \\
\hline & $\begin{array}{l}\text { Interior } \\
\text { Highlands }\end{array}$ & $\begin{array}{l}\text { Buttram } \\
\text { Hollow, Ava } \\
\text { Ranger } \\
\text { District, } \\
\text { Missouri }\end{array}$ & $\begin{array}{l}\text { Juniperus } \\
\text { virginiana }\end{array}$ & $\begin{array}{l}3.2 \\
22.0\end{array}$ & $\begin{array}{l}1730-1870 \\
1870-1980\end{array}$ & MFI & 259 ha & 96 & 21 & $\mathrm{Y}$ & $\mathrm{N}$ & $\mathrm{N}$ & $\mathrm{Y}$ & $\begin{array}{l}\text { Guyette \& } \\
\text { McGinnes } \\
1982\end{array}$ \\
\hline & $\begin{array}{l}\text { Interior } \\
\text { Highlands }\end{array}$ & $\begin{array}{l}\text { Current River } \\
\text { Watershed, } \\
\text { Van Buren, } \\
\text { Missouri }\end{array}$ & Pinus echinata & $\begin{array}{l}17.7 \\
12.4 \\
3.7\end{array}$ & $\begin{array}{l}1580-1700 \\
1701-1820 \\
1821-1940\end{array}$ & MFI & $\begin{array}{l}431,600 \\
\text { ha }\end{array}$ & 2,004 & 150 & $\mathrm{Y}$ & $\mathrm{N}$ & $\mathrm{N}$ & $\mathrm{Y}$ & $\begin{array}{l}\text { Guyette \& } \\
\text { Cutter 1997; } \\
\text { Batek et al. } \\
1999 ; \\
\text { Guyette et al. } \\
2002\end{array}$ \\
\hline
\end{tabular}




\begin{tabular}{|c|c|c|c|c|c|c|c|c|c|c|c|c|c|c|}
\hline \multirow{6}{*}{ 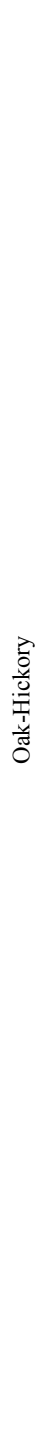 } & Sub-region & $\begin{array}{c}\text { Study } \\
\text { Location }\end{array}$ & Species & $\begin{array}{c}\text { Fire } \\
\text { Interval } \\
\text { (years) }\end{array}$ & Chronology & $\begin{array}{c}\text { Interval } \\
\text { Method** }\end{array}$ & $\begin{array}{l}\text { Size of } \\
\text { Study } \\
\text { Area }\end{array}$ & $\begin{array}{l}\text { Number of } \\
\text { Fire Scars }\end{array}$ & $\begin{array}{c}\text { Sample } \\
\text { Size }\end{array}$ & $\begin{array}{c}\text { Cross- } \\
\text { dated? } \\
(\mathbf{Y} / \mathbf{N})^{* * *}\end{array}$ & $\begin{array}{c}\text { Fire } \\
\text { Extent? } \\
\text { (Y/N) }\end{array}$ & $\begin{array}{c}\text { Seasonality? } \\
(\mathbf{Y} / \mathbf{N})\end{array}$ & $\begin{array}{l}\text { Intensity/ } \\
\text { Severity? } \\
\text { (Y/N) }\end{array}$ & Reference \\
\hline & $\begin{array}{l}\text { Interior } \\
\text { Highlands }\end{array}$ & $\begin{array}{l}\text { Boston } \\
\text { Mountains, } \\
\text { Pope County, } \\
\text { Arkansas }\end{array}$ & Pinus echinata & $\begin{array}{l}4.6-13.0 \\
2.0-3.1 \\
1.4-5.0 \\
62-80+\end{array}$ & $\begin{array}{l}1680-1820 \\
1821-1880 \\
1881-1920 \\
1921-2000\end{array}$ & MFI & $\begin{array}{l}3,50- \\
200 \text { ha }\end{array}$ & 309 & 45 & $\mathrm{Y}$ & $\mathrm{Y}$ & $\mathrm{Y}$ & $\mathrm{Y}$ & $\begin{array}{l}\text { Guyette \& } \\
\text { Spetich } 2003\end{array}$ \\
\hline & $\begin{array}{l}\text { Interior } \\
\text { Highlands }\end{array}$ & $\begin{array}{l}\text { Huckleberry } \\
\text { Hollow, } \\
\text { Shannon } \\
\text { County, } \\
\text { Missouri }\end{array}$ & Pinus echinata & $\begin{array}{l}7.1 \\
2.2\end{array}$ & $\begin{array}{l}1700-1820 \\
1821-1930\end{array}$ & MFI & $930 \mathrm{ha}$ & $\mathrm{N} / \mathrm{A}$ & 9 & Y & $\mathrm{N}$ & $\mathrm{N}$ & $\mathrm{Y}$ & $\begin{array}{l}\text { Guyette \& } \\
\text { Dey } 1997\end{array}$ \\
\hline & $\begin{array}{l}\text { Interior } \\
\text { Highlands }\end{array}$ & $\begin{array}{l}\text { Panther Cave, } \\
\text { Carter County, } \\
\text { Missouri }\end{array}$ & Pinus echinata & $\begin{array}{l}4.4 \\
3.75\end{array}$ & 1604-1996 & $\begin{array}{l}\text { MFI } \\
\text { WMedPI }\end{array}$ & $100 \mathrm{ha}$ & 106 & 12 & $\mathrm{Y}$ & $\mathrm{Y}$ & $\mathrm{N}$ & $\mathrm{Y}$ & $\begin{array}{l}\text { Guyette \& } \\
\text { Stambaugh } \\
2002\end{array}$ \\
\hline & $\begin{array}{l}\text { Interior } \\
\text { Highlands }\end{array}$ & $\begin{array}{l}\text { Turkey } \\
\text { Mountain, } \\
\text { Buffalo } \\
\text { National } \\
\text { River, } \\
\text { Arkansas }\end{array}$ & Pinus echinata & 5.7 & 1770-1993 & MFI & $700 \mathrm{ha}$ & 54 & 9 & $\mathrm{Y}$ & $\mathrm{Y}$ & $\mathrm{N}$ & $\mathrm{Y}$ & $\begin{array}{l}\text { Jenkins et al. } \\
1997\end{array}$ \\
\hline & $\begin{array}{l}\text { Interior } \\
\text { Highlands }\end{array}$ & $\begin{array}{l}\text { Big Spring } \\
\text { Pines Natural } \\
\text { Area, } \\
\text { Missouri }\end{array}$ & Pinus echinata & 2.8 & 1634-1974 & MFI & 80 ha & 193 & 19 & Y & $\mathrm{Y}$ & $\mathrm{Y}$ & Y & $\begin{array}{l}\text { Stambaugh et } \\
\text { al. } 2005\end{array}$ \\
\hline
\end{tabular}




\begin{tabular}{|c|c|c|c|c|c|c|c|c|c|c|c|c|c|c|}
\hline \multirow{4}{*}{ 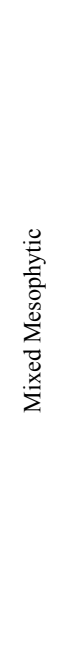 } & Sub-region & $\begin{array}{c}\text { Study } \\
\text { Location }\end{array}$ & Species & $\begin{array}{c}\begin{array}{c}\text { Fire } \\
\text { Interval } \\
\text { (years) }\end{array} \\
\end{array}$ & Chronology & $\begin{array}{c}\text { Interval } \\
\text { Method** }\end{array}$ & $\begin{array}{l}\text { Size of } \\
\text { Study } \\
\text { Area }\end{array}$ & $\begin{array}{l}\text { Number of } \\
\text { Fire Scars }\end{array}$ & $\begin{array}{c}\text { Sample } \\
\text { Size }\end{array}$ & $\begin{array}{c}\text { Cross- } \\
\text { dated? } \\
(\mathbf{Y} / \mathbf{N})^{* * *}\end{array}$ & $\begin{array}{c}\text { Fire } \\
\text { Extent? } \\
(\mathbf{Y} / \mathbf{N})\end{array}$ & $\begin{array}{c}\text { Seasonality? } \\
(\mathbf{Y} / \mathbf{N})\end{array}$ & $\begin{array}{c}\text { Intensity/ } \\
\text { Severity? } \\
\text { (Y/N) }\end{array}$ & Reference \\
\hline & $\begin{array}{l}\text { Allegheny } \\
\text { Mountains }\end{array}$ & $\begin{array}{l}\text { Savage River } \\
\text { State Forest, } \\
\text { Western } \\
\text { Maryland }\end{array}$ & Quercus spp. & 7.6 & 1615-1958 & WModPI & $\sim 325 \mathrm{ha}$ & 138 & 20 & $\mathrm{Y}$ & $\mathrm{Y}$ & $\mathrm{Y}$ & $\mathrm{Y}$ & $\begin{array}{l}\text { Shumway et } \\
\text { al. 2001; } \\
\text { Abrams } 2000\end{array}$ \\
\hline & $\begin{array}{l}\text { Allegheny } \\
\text { Plateau }\end{array}$ & $\begin{array}{l}\text { Racoon } \\
\text { Ecological } \\
\text { Management } \\
\text { Area, Vinton } \\
\text { County, Ohio }\end{array}$ & Quercus spp. & $\begin{array}{l}5.4 \\
3.6\end{array}$ & 1856-1995 & $\begin{array}{c}\text { MFI } \\
\text { WMedPI }\end{array}$ & 8 ha & 48 & 14 & $\mathrm{Y}$ & $\mathrm{Y}$ & $\mathrm{Y}$ & $\mathrm{Y}$ & $\begin{array}{c}\text { Sutherland } \\
1997\end{array}$ \\
\hline & $\begin{array}{l}\text { Cumberland } \\
\text { Plateau }\end{array}$ & $\begin{array}{l}\text { Arnold Air } \\
\text { Force Base, } \\
\text { Coffee } \\
\text { County, } \\
\text { Tennessee }\end{array}$ & Quercus stellata & 7.7 & $1850-1950$ & MFI & 3 ha & 18 & 20 & $\mathrm{Y}$ & $\mathrm{N}$ & $\mathrm{N}$ & $\mathrm{Y}$ & $\begin{array}{l}\text { Guyette \& } \\
\text { Stambaugh } \\
2004\end{array}$ \\
\hline & Hill Section & $\begin{array}{l}\text { Hoosier } \\
\text { National } \\
\text { Forest, } \\
\text { Indiana }\end{array}$ & Quercus stellata & 8.4 & 1656-1992 & MFI & 75 ha & 84 & 27 & $\mathrm{Y}$ & $\mathrm{Y}$ & $\mathrm{N}$ & $\mathrm{N}$ & $\begin{array}{l}\text { Guyette et al. } \\
2003\end{array}$ \\
\hline 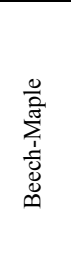 & $\begin{array}{l}\text { (Though } \\
\text { considered } \\
\text { Beech-Maple } \\
\text { Forest, this } \\
\text { region contains } \\
\text { significant } \\
\text { patches of } \\
\text { Oak-Hickory } \\
\text { forest) }\end{array}$ & $\begin{array}{l}\text { Indiana Dunes } \\
\text { National } \\
\text { Lakeshore, } \\
\text { Lake } \\
\text { Michigan, } \\
\text { Indiana }\end{array}$ & $\begin{array}{l}\text { Quercus } \\
\text { velutina, } \\
\text { Quercus alba }\end{array}$ & $5.2-11.1$ & 1929-1979 & MFI & $\begin{array}{l}2,160- \\
\text { ha sites }\end{array}$ & 171 & 38 & $\mathrm{~N}$ & $\mathrm{Y}$ & $\mathrm{N}$ & $\overline{\mathrm{Y}}$ & $\begin{array}{l}\text { Henderson \& } \\
\text { Long } 1985\end{array}$ \\
\hline
\end{tabular}

Table 1: Summary of the fire history studies conducted in the Central Hardwood Forests. * - MFI calculated by author. ** - MFI is the Mean Fire-free Interval. WModPI is the Weibull Modal Probability Interval. WMedPI is the Weibull Median Probability Interval. 


\begin{tabular}{lll}
\hline Database & Internet Address & Search Word(s) \\
\hline AGRICOLA & http://agricola.nal.usda.gov & fire history \\
Google Scholar & www.scholar.google.com & fire history \\
EbscoHost & www.ebscohost.com & fire history \\
The Nature Conservancy & www.conserveonline.org & fire management \\
USDA Forest Service TreeSearch & www.treesearch.fs.fed.us & fire, fire history \\
Bibliography of Dendrochronology & http://www01.wsl.ch/dendrobiblio/ & fire \\
Tall Timbers Fire Ecology Database & www.talltimbers.org & fire history \\
\hline
\end{tabular}

Table 2: Databases searched for fire history literature with internet addresses and search word(s) used. All databases were last accessed December, 2005. 


\section{CHAPTER 3: METHODS}

\subsection{Study Area Description}

The study area consists of a linear stand ( $~ 100 \mathrm{ha})$ located $4 \mathrm{~km}$ east of Fayetteville, WV along the "Endless Wall” in the New River Gorge National River $\left(38^{\circ} 03^{\prime} 15^{\prime \prime} \mathrm{N}, 81^{\circ} 03^{\prime} 32^{\prime \prime} \mathrm{W}\right.$; Fayetteville 7.5-min. quadrangle; Fig. 4). The Endless Wall is a 15-35 m sandstone cliff that extends approximately $6 \mathrm{~km}$ (3.7 miles) along the northern section of the gorge (Fig. 5). This site was chosen because it is the largest contiguous segment of the rimrock pine forest type within the park.

Geologically, the site is composed of the coal-bearing New River Formation of the Pottsville group. This formation contains the Fire Creek, Beckley, and Sewell coal seams as well as siltstone, shale, and sandstone components. The Nuttall sandstone layer tops the formation creating the highly erosion-resistant cliffs that are prominent along the Endless Wall (Lessing 1986). The very stony soils along the Endless Wall are characterized by the Dekalb and Gilpin series derived from Nuttall sandstone parent material (United States Department of Agriculture 1975). Jenkins (2005) described the forest floor on top of the south-facing cliffs as having a thin O horizon (2 to $7 \mathrm{~cm}$ thick) and shallow A horizon (usually less than $50 \mathrm{~cm}$ ) that is coarse, welldrained, drought prone, and having low fertility. Due primarily to foot travel along popular hiking trails and overlooks, significant portions of the rimrock have experienced compaction, erosion, and limited plant colonization.

The study site is located along a south-facing aspect of the gorge at an elevation of $580 \mathrm{~m}$ (1900 ft) with slope inclination ranging from 0 to $40 \%$. The mean annual temperature is $10.5^{\circ} \mathrm{C}$ $\left(50.9^{\circ} \mathrm{F}\right)$ with the high and low mean monthly temperatures of $20.9^{\circ} \mathrm{C}\left(69.7^{\circ} \mathrm{F}\right)$ and $-1.6^{\circ} \mathrm{C}$ $\left(29.2^{\circ} \mathrm{F}\right)$ recorded in July and January, respectively. The growing season extends from mid- 


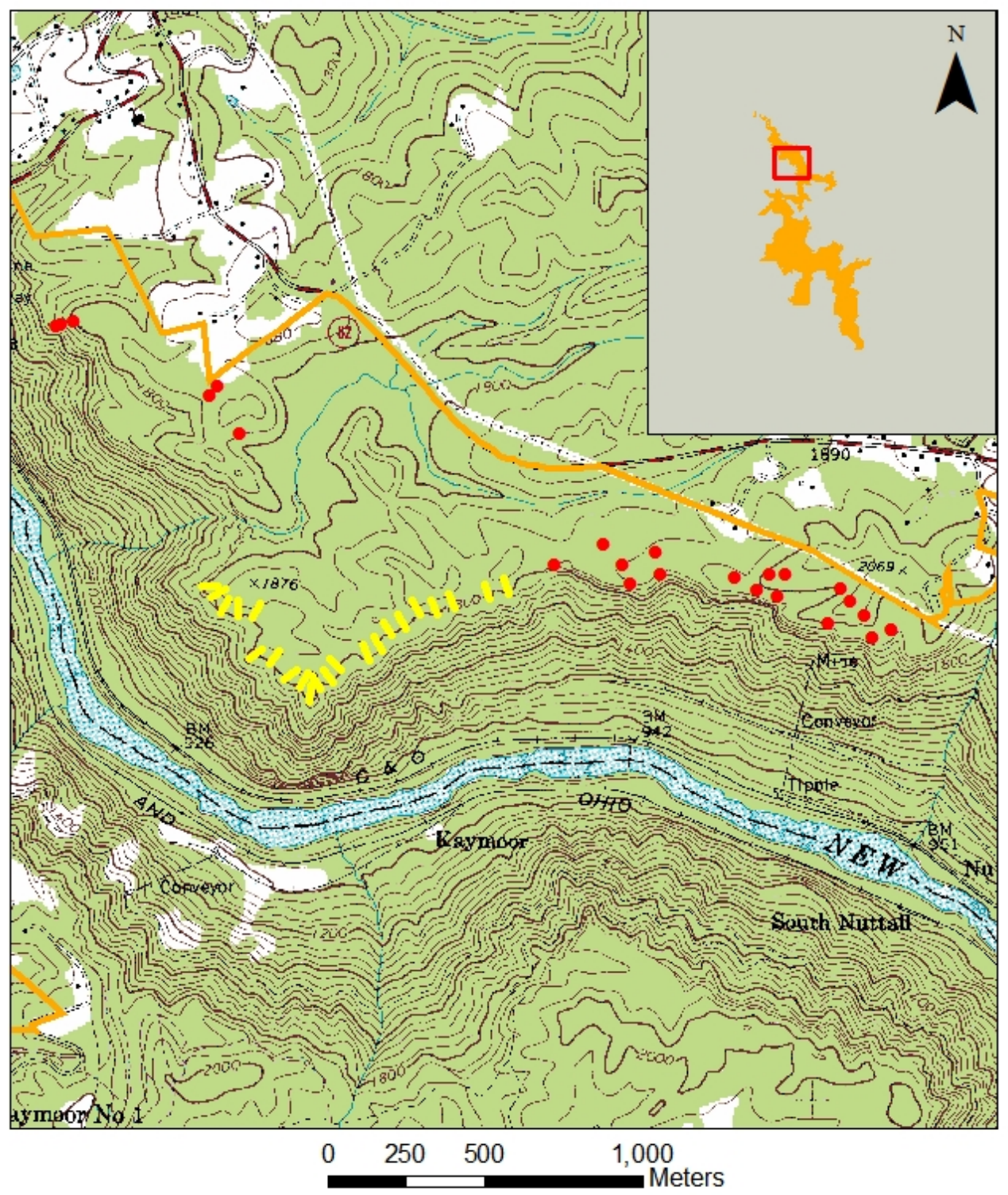

\section{Legend}

- Cross Sections $\longrightarrow$ Transects $\square$ Park Boundary

Figure 4: Location of sample transects and cross sections. 
April to mid-October. A nearby weather station (Beckely, WV) reported an average of $104.2 \mathrm{~cm}$ (41.0 in) of precipitation per year with snowfall, ice pellets, and hail averaging $48.8 \mathrm{~cm}$ (19.2 in) of the total. While more precipitation occurs during the summer season than the winter season, there is no defined dry period for the area (Suiter and Evans 1995).

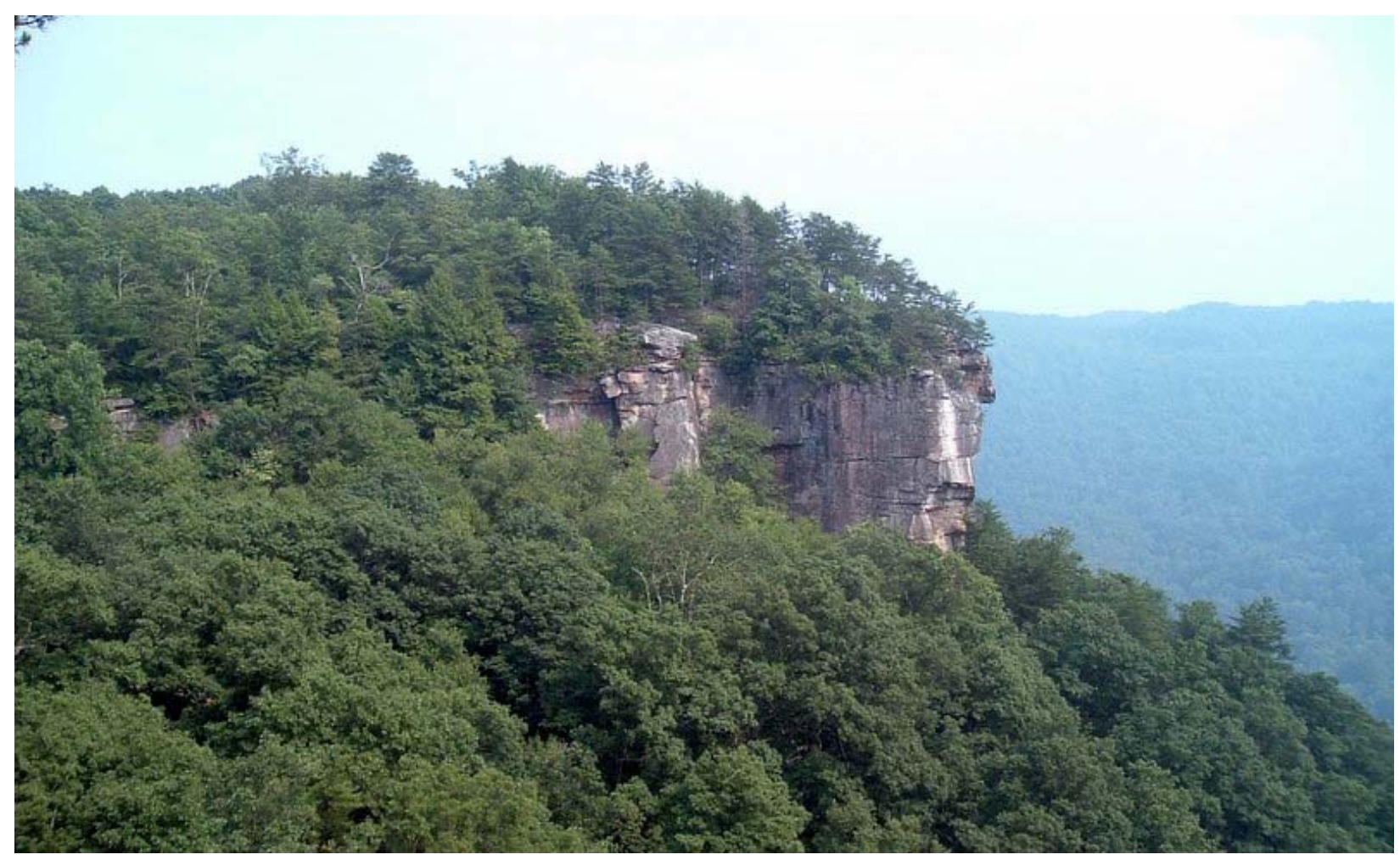

Figure 5: Photo of the sandstone cliffs that compose the Endless Wall.

\subsection{Vegetation Survey}

Twenty-two transects $(50 \mathrm{~m} \times 6 \mathrm{~m})$, broken into 5 adjacent $10 \mathrm{~m} \times 6 \mathrm{~m}$ sections for data collection and analysis purposes, were used to sample the rimrock pine community (Fig. 6). Each transect originated at the cliff edge in the predominately pine cover type and was oriented perpendicular to the cliff extending into the hardwood community. While a spacing of at least $60 \mathrm{~m}$ between transects was used, the location of an individual transect depended upon the 
presence of overstory $P$. virginiana and the ability to safely sample the vegetation. All trees, with any portion of the stem falling within a transect and greater than $2.54 \mathrm{~cm}(1 \mathrm{in})$ diameter at breast height (DBH), were identified to species. Total height, crown class, vigor, longevity, and time since tree death (for standing dead) were collected. Specifically, crown class was separated into dominant, codominant, intermediate, and overtopped (Smith et al. 1997). A vigor rating of 1 to 7 was assigned for each tree: 1) healthy crown, 2) minor dieback, 3) some dieback but $>50 \%$ alive, 4) $>50 \%$ of crown dead with some live branches, 5) crown completely dead with some stem and basal sprouts, 6) crown completely dead with some basal sprouts, or 7) dead tree. Longevity was estimated in addition to the vigor rating: 1) $>20$ yrs to live (for vigor ratings 1 and 2), 2) 10-20 yrs to live (for vigor ratings 3 and 4), or 3 ) $<10$ yrs to live (for vigor ratings 5 and 6). Time since tree death was ranked: 1) $<5$ yrs since death (fine limbs and tight bark), 2) 5-10 yrs since death (large limbs and bole with substantial bark), or 3) $>10$ yrs since death (no bark only stem remains). Individual species characteristics were taken into account for vigor, longevity, and mortality ratings.

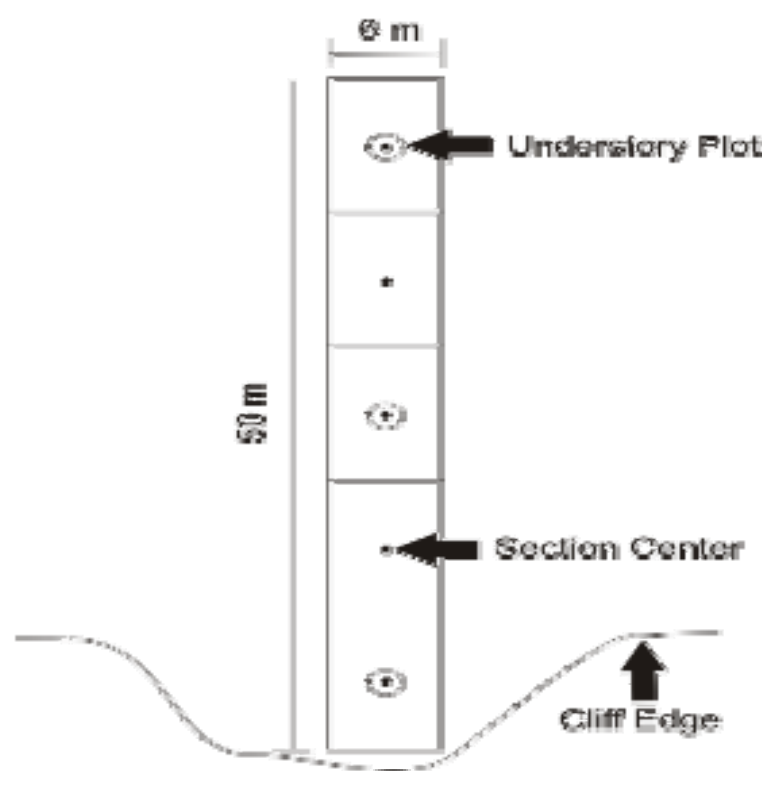

Figure 6: Diagram of sample transect layout. 
Three circular understory plots (2-m diameter) were established in each transect, with one plot each in the pine, ecotone, and hardwood portions of the forest. These zones were subjectively identified in the field for each transect, however, plots were typically located at $5 \mathrm{~m}$ (pine), $25 \mathrm{~m}$ (ecotone), and $45 \mathrm{~m}$ (hardwood). In each plot, percent cover of herbaceous plants and shrubs was estimated and dominant species were identified. Woody vegetation was identified to species, counted, and assigned a size class: 1) germinals $(<15 \mathrm{~cm}), 2) 1$ year+ but not established (15 cm-1.23 m), or 3) established ( $>1.23 \mathrm{~m} /<2.54 \mathrm{~cm} \mathrm{DBH})$.

\subsection{Vegetation Data Analysis}

Average ratings of total height, crown class, vigor, and longevity, as well as percent mortality were calculated for each species to provide a subjective snapshot of the overstory structure and health of the rimrock community. Percent of understory woody vegetation assigned to each size class was averaged for each species in the pine, ecotone, and hardwood plots. Percent cover of shrubs and herbaceous plants were averaged for each portion of the forest.

For each $6 \mathrm{~m} \times 10 \mathrm{~m}$ overstory section, density, dominance (i.e., basal area), and importance values were calculated for each species. Density was calculated as the number of individuals per hectare. Dominance was estimated as the total basal area per hectare. Species importance value (IV) indices were calculated as one-half the sum of the relative density and relative dominance for each species (Smith et al. 1997). Additionally, frequency was determined as the number of sections occupied by a given species and was used as a measure of species distribution across the site. Understory data were analyzed with similar methods except species IV utilized relative frequency and relative density. 
Community composition patterns were assessed using cluster analysis of the overstory trees using the program PC-ORD (McCune and Mefford 1999). A main matrix of species IVs for each transect section was constructed. This method was chosen to determine if sections at each distance were similar throughout the study site. Following the initial cluster analysis, a second matrix was developed to identify a pine group (sections 1 and 2) and a hardwood group (sections 3, 4, and 5) across the study area. These groupings were based on field observations and preliminary data analysis of the dominant vegetation type in each section of the sample transects. The Sorenson (Bray-Curtis) distance was used as the mathematical distance measure in the cluster analysis and the farthest neighbor as the method of linkage. To reduce the number of null values in the data set, species occurring in fewer than 6 plots were removed from the analysis. Analysis of understory species IVs followed a similar procedure except the second matrix defined 3 a priori groups at $5 \mathrm{~m}$ (pine), $25 \mathrm{~m}$ (ecotone), and $45 \mathrm{~m}$ (hardwood). However, this method of understory grouping was insufficient to identify meaningful groups and a second matrix was constructed using to 2 groups, pine $(5 \mathrm{~m})$ and hardwood ( $25 \mathrm{~m}$ and $45 \mathrm{~m}$ ).

A multi-response permutation procedure (MRPP, McCune and Mefford 1999) was conducted to assess the strength of the cluster analysis and to determine within-group homogeneity of a priori overstory plot groups. MRPP is a nonparametric technique used to test the hypothesis of no difference between two or more groups of entities (McCune et al. 2002). In the procedure, an average Sorenson distance within each group is calculated from a distance matrix. Observed and expected weighted mean within-group distances $(\delta)$ are determined and a test statistic $(T)$ is generated to describe the separation between the groups. Stronger separations between groups are represented by more negative $T$ values. A $p$ value is then used to evaluate the likelihood that the observed difference $(T)$ is due to chance. The size of the effect is 
described by the chance-corrected within-group agreement (A), with an observed $\delta=0$ and $A=1$ returned when all items are identical within groups. In community ecology, $A$ values below 0.1 are common, even when observed $\delta$ differs significantly from the expected value (McCune et al. 2002).

\subsection{Dendrochronological Sampling}

Following preliminary data analysis of species composition and distribution within the study site, a total of 50 representative overstory and understory trees were cored to determine the age structure of the community and construct master chronologies of dominant species (Table 3). Samples were taken from three representative overstory transects and were selectively chosen to target Pinus virginiana, Quercus spp., Oxydendrum arboreum, Nyssa sylvatica, and Acer

rubrum. Thus, the cored trees do no represent a random sample. Two cores were removed from opposite sides of each tree at $0.5 \mathrm{~m}$ above the ground. Cores were extracted perpendicular to slope direction to avoid sampling of compression or reaction wood (Phipps 1985).

\begin{tabular}{lccc}
\hline \multicolumn{1}{c}{ Species } & Overstory & Understory & Total \\
\hline Pinus virginiana & 14 & 0 & 14 \\
Pinus rigida & 3 & 0 & 3 \\
Quercus coccinea & 4 & 0 & 4 \\
Quercus alba & 3 & 0 & 3 \\
Quercus velutina & 2 & 0 & 2 \\
Carya spp. & 0 & 2 & 2 \\
Nyssa sylvatica & 0 & 7 & 7 \\
Oxydendrum arboreum & 0 & 7 & 7 \\
Acer rubrum & 4 & 4 & 8 \\
\hline TOTAL & & & 50
\end{tabular}

Table 3: Species composition and canopy position of trees sampled for age structure. 
To assess the fire history of the rimrock community, 23 cross sections were collected from fire-scared live and dead $P$. virginiana $(\mathrm{n}=22)$ and $P$. rigida $(\mathrm{n}=1)$ throughout the study area. During sampling, an effort was made to sample hazard trees and preserve the ecological integrity of the forest.

\subsection{Dendrochronological Analysis}

Increment cores and cross sections were returned to the laboratory to be dried, mounted (cores only), and sanded according to standard dendrochronological techniques (Stokes and Smiley 1968). Cores were skeleton plotted and visually crossdated by matching narrow tree-ring widths to accurately assign a year to each ring. Tree rings of Oxydendrum arboreum and Nyssa sylvatica samples could not be crossdated due to the difficulty identifying boundaries between annual rings, but rings were counted to estimate year of establishment. Annual radial growth was measured to the nearest $0.001 \mathrm{~mm}$ using a Velmex measuring system in conjunction with Measure $\mathrm{J}_{2} \mathrm{X}^{\circledR}$ software. The accuracy of crossdating was assessed by statistically comparing the raw ring widths using the computer program COFECHA (Grissino-Mayer 2001a).

Discrepancies in crossdating were corrected and 4 cores that did not crossdate were removed from the analysis.

Raw ring widths from 18 pines and 10 oaks were used to identify moderate and major releases (Lorimer and Frehlich 1989). A moderate release was defined as a $25 \%$ increase in radial growth sustained for a minimum of 10 years. A major release was defined as at least a $50 \%$ increase in radial growth sustained for a minimum of 10 years (Nowacki and Abrams 1997). The first year of the 10 -year span was identified as the release year.

The ARSTAN program (Cook and Holmes 1990) was used to detrend each series with a negative exponential curve or a negative linear function. This standardization procedure 
removed the effects of tree aging, bole geometry, and microsite conditions in order to develop a standardized ring-width series (Fritts and Swetnam 1989). The procedure was used to detrend ring-width measurements and create master chronologies for Pinus, Quercus, and Acer genera.

All fire scars from each cross section were then crossdated against the Pinus master chronology and a Pinus pungens chronology from the Ridge and Valley province (Sutherland et al. 1993). Seasonality of each fire scar was determined by noting the position of the scar within the annual tree ring (Dieterich and Swetnam 1984). Fire scars located between the latewood of one growth ring and the earlywood of the next growth ring were identified as dormant season events. Dormant season events were assigned to the year of the last full growth ring. Thus, a fire burning during the dormant season of 1953 may have occurred in fall of 1953 or the spring of 1954.

Distributions of fire scar dates may not be adequately described by symmetrical measures of central tendency because there is no upper bound to fire-free periods and the lower bound may never be negative (Schuler and McClain 2003). Grissino-Mayer (2001b) suggested that a twoparameter Weibull distribution would be more appropriate to characterize such distributions because fire scar dates tend to be positively skewed. With the Weibull distribution, a 0.50 exceedance probability is the $50^{\text {th }}$ percentile, or the central tendency, of the distribution. Fire scar dates, seasonality, and inner and outer dates of each samples were entered into the software program $\mathrm{FHX} 2^{\circledR}$ to evaluate the goodness of fit between the fire intervals and the empirical and Weibull distributions using a one-sample Kolmogorov-Smirnov (K-S) test (Grissino-Mayer 2001b). Following the methods of Schuler and McClain (2003), two criteria (conservative and liberal) were used to estimate composite fire intervals. The conservative criterion was a year when 2 or more trees recorded a fire event. The liberal criterion was a year when only 1 tree had 
a fire scar. Additionally, box plots were created to display the median, quartile, and minimum and maximum fire interval values for each sample location and both site combined. 


\section{CHAPTER 4: RESULTS}

\subsection{Overstory Vegetation}

\subsubsection{Overstory Structure and Composition}

The rimrock pine forest type was composed of Pinus virginiana, Nyssa sylvatica, Oxydendrum arboreum, Acer rubrum, Quercus spp., and other hardwoods (Fig. 7). Though $P$. virginiana was the dominant species in the overstory, its abundance was not equally spread throughout the sample area. Its prevalence in the canopy decreased from approximately $64 \%$ of the stems in the first $10-\mathrm{m}$ section of transects to less than $5 \%$ in the last section. As distance from the rim of the gorge increased, the decrease in percentage of $P$. virginiana stems was compensated by an increase in N. sylvatica, O. arboreum, A. rubrum, and other deciduous stems. Quercus spp. stems were present in modest amounts ranging from 9-16\% of the total number of stems in each section.

A modified inverse $\mathrm{J}$-shaped diameter distribution curve was observed with more trees in the smaller diameter classes and fewer trees in the larger diameter classes (Fig. 8). In general, smaller diameter trees were found near the rim of the gorge with the exception of several largediameter $(>30 \mathrm{~cm})$ oaks and pines. Intermediate and overtopped species, such as black gum, sourwood, and red maple, composed the majority (58\%) of the smallest diameter classes ( $0-10$ $\mathrm{cm})$. When examining the diameter distribution of Virginia pine alone, a skewed normal distribution curve was present which may indicate that this component was approximately evenaged.

The most important canopy species, in descending order, were Pinus virginiana, Nyssa sylvatica, Oxydendrum arboreum, Quercus coccinea, Acer rubrum, Quercus prinus, and 
Quercus alba (Table 4). Of these species, the dominant and codominant crown classes were occupied by P. virginiana and Quercus spp. with the N. sylvatica, O. arboreum, and A. rubrum in the intermediate and overtopped classes. Height of $P$. virginiana averaged $6.85 \mathrm{~m}$ compared to a mean of $11.11 \mathrm{~m}$ for Quercus spp., but the majority of pines were located near the cliff edge where all trees were shorter. P. virginiana had the highest density and basal area of all rimrock species; however, it did not have the greatest frequency. The Quercus spp. composed the second greatest basal area despite having a lower density and frequency than other prominent species. N. sylvatica, O. arboreum, and A. rubrum had the greatest distributions (i.e., frequency) across the study area with corresponding high densities and low dominance.

Most species present on the rimrock showed some signs of crown dieback (Table 4). Mean vigor (1-7 scale, with 1 being a healthy tree and 7 being a dead tree) of canopy species ranged from 2.82 for Quercus prinus to 3.62 for Quercus coccinea. Despite signs of dieback, expected longevity of canopy species is greater than 20 years based on overall tree health and silvical characteristics. Percent mortality (i.e., count of standing dead trees/count of living trees x 100) for the most important species ranged from $6.9 \%$ for $N$. sylvatica to $20 \%$ for $Q$. coccinea.

\subsubsection{Overstory Grouping}

A cluster analysis was conducted to separate transect sections into pine (sections 1 and 2) and hardwood (sections 3, 4, and 5) groupings that were previously defined by field observations and preliminary data analysis. The resulting dendrogram (Fig. 9) showed grouping of transect sections with a low percentage of chaining (3.13\%). Two section-1 groups and six section-2 groups did not cluster into the pine component and were replaced by hardwood sections. The MRPP results confirm the presence of pine and hardwood components with a negative $T$-statistic 
$(T=-25.832)$ that was highly significant $(\mathrm{p}<0.001)$. The A-statistic was acceptable $(\mathrm{A}=0.105)$ for studies of community ecology (McCune et al. 2002). 


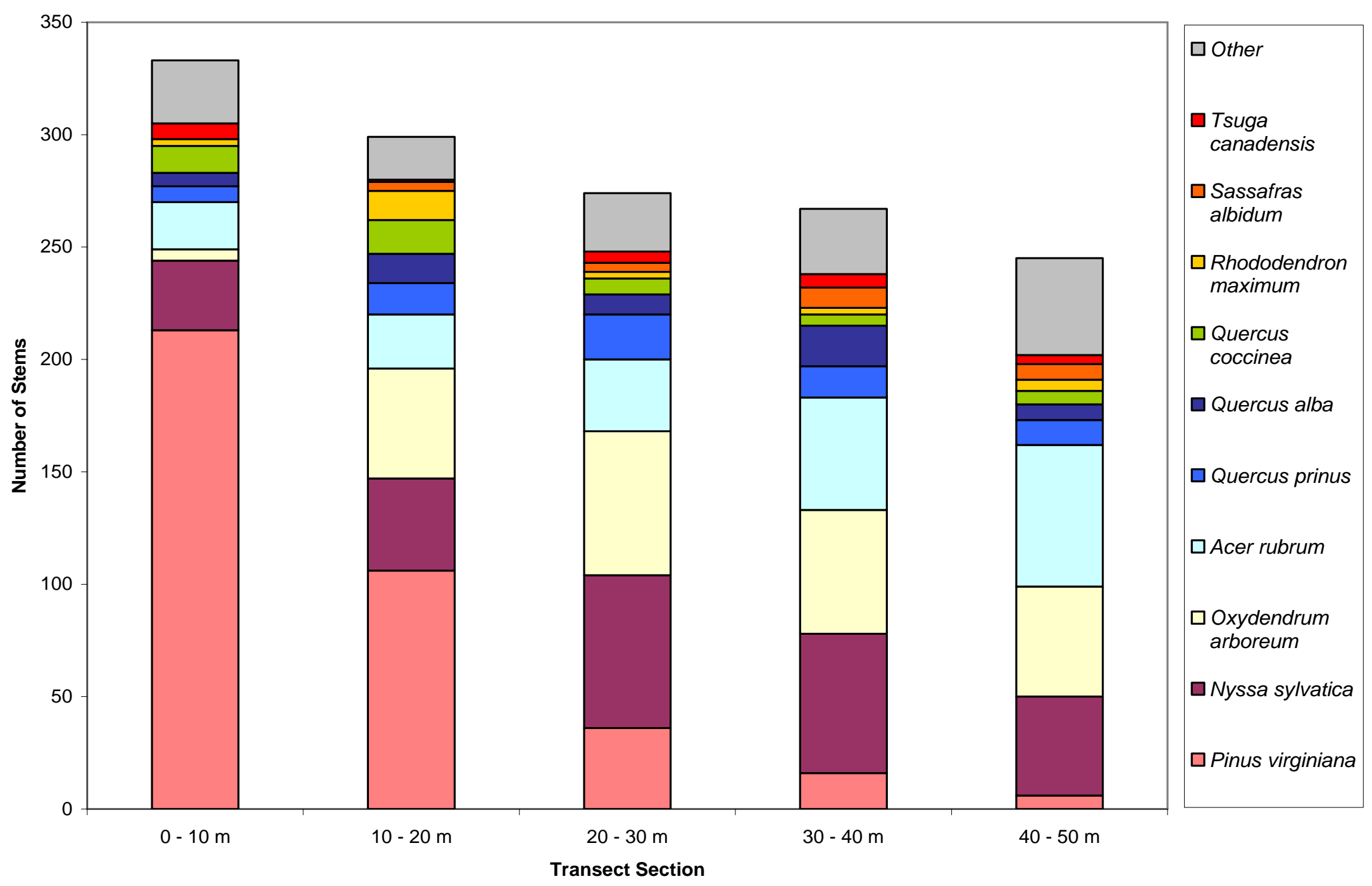

Figure 7: Number of stems by species for each section of sample transects. 


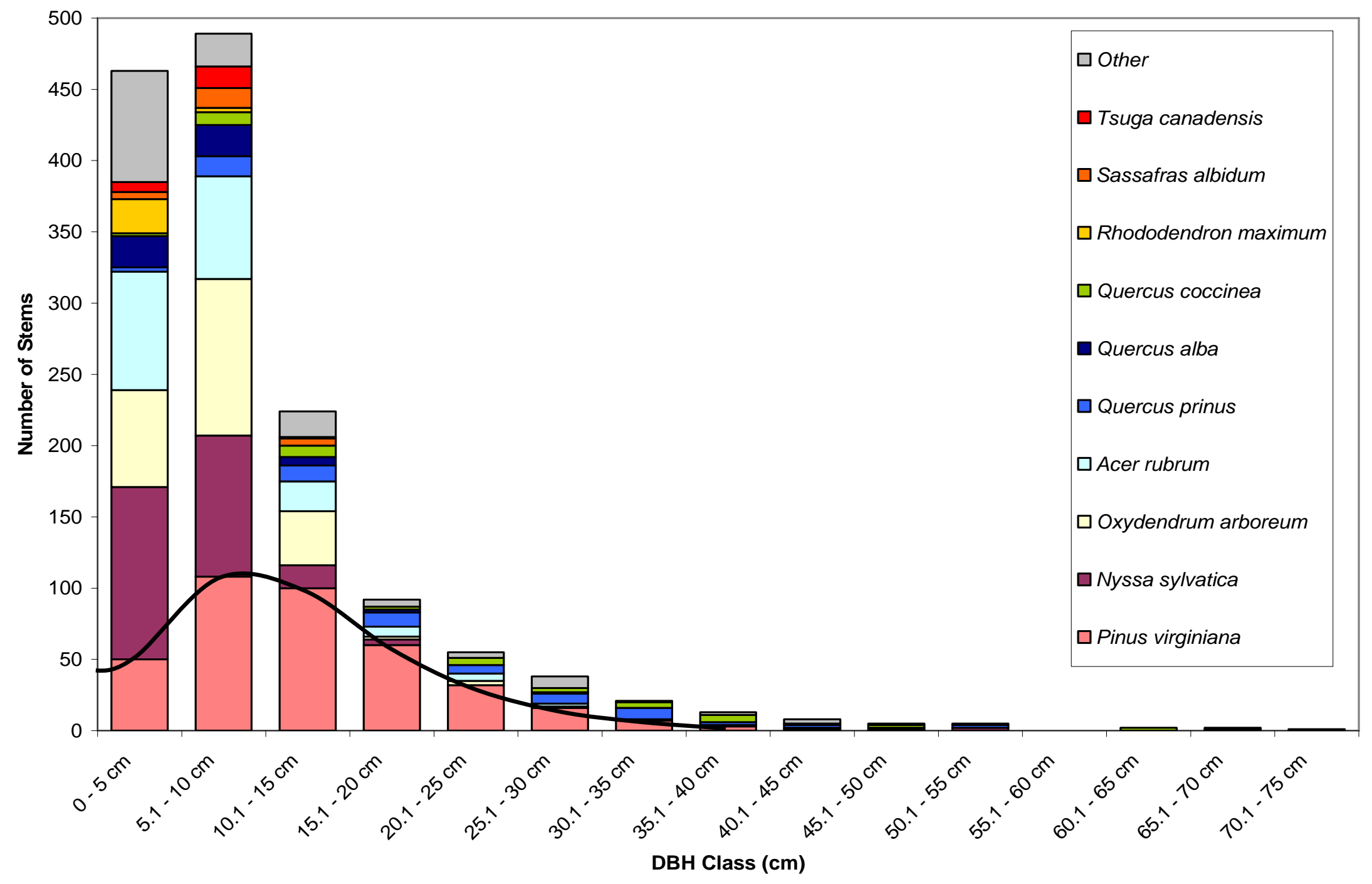

Figure 8: Diameter distribution by species from 22 sample transects along the "Endless Wall" portion of the rimrock pine forest. The bold curve represents the skewed normal distribution of Pinus virginiana DBH. 


\begin{tabular}{|c|c|c|c|c|c|c|c|c|c|c|c|c|c|}
\hline Species & $\begin{array}{c}\text { Average } \\
\text { DBH (cm) }\end{array}$ & $\begin{array}{c}\begin{array}{c}\text { Average } \\
\text { Height }(\mathrm{m})\end{array} \\
\end{array}$ & $\begin{array}{c}\text { Average } \\
\text { Class }\end{array}$ & $\begin{array}{c}\text { Average } \\
\text { Vigor }\end{array}$ & $\begin{array}{c}\begin{array}{c}\text { Average } \\
\text { Longevity }\end{array} \\
\end{array}$ & $\begin{array}{c}\text { Percent } \\
\text { Mortality }\end{array}$ & $\begin{array}{l}\text { Frequency } \\
\text { (\# of plots) }\end{array}$ & $\begin{array}{c}\text { Density } \\
\text { (Stems/HA) }\end{array}$ & $\begin{array}{c}\text { Dominance } \\
\left(B A \text { in } m^{2}\right)\end{array}$ & $\begin{array}{c}\text { Relative } \\
\text { Frequency }\end{array}$ & $\begin{array}{l}\text { Relative } \\
\text { Density }\end{array}$ & $\begin{array}{c}\text { Relative } \\
\text { Dominance }\end{array}$ & $\begin{array}{c}\text { Importance } \\
\text { Value }\end{array}$ \\
\hline Pinus virginiana & 12.76 & 6.85 & 2.38 & 3.19 & 1.40 & 11.14 & 54.00 & 876.74 & 6.45 & 11.79 & 26.61 & 29.89 & 28.25 \\
\hline Nyssa sylvatica & 6.60 & 4.85 & 3.63 & 3.14 & 1.56 & 6.91 & 68.00 & 572.09 & 1.66 & 14.85 & 17.36 & 7.68 & 12.52 \\
\hline Oxydendrum arboreum & 7.35 & 5.73 & 3.44 & 3.45 & 1.68 & 9.91 & 63.00 & 516.28 & 1.26 & 13.76 & 15.67 & 5.83 & 10.75 \\
\hline Quercus coccinea & 25.26 & 11.33 & 2.16 & 3.62 & 1.24 & 20.00 & 28.00 & 104.65 & 3.37 & 6.11 & 3.18 & 15.61 & 9.39 \\
\hline Acer rubrum & 7.09 & 6.94 & 3.51 & 3.02 & 1.23 & 12.63 & 54.00 & 441.86 & 1.11 & 11.79 & 13.41 & 5.14 & 9.28 \\
\hline Quercus prinus & 20.16 & 10.25 & 2.30 & 2.83 & 1.21 & 9.09 & 35.00 & 153.49 & 2.88 & 7.64 & 4.66 & 13.37 & 9.01 \\
\hline Quercus alba & 17.76 & 11.03 & 2.42 & 3.13 & 0.96 & 18.87 & 34.00 & 123.26 & 1.93 & 7.42 & 3.74 & 8.94 & 6.34 \\
\hline Quercus velutina & 16.12 & 8.27 & 2.71 & 3.12 & 1.88 & 0.00 & 9.00 & 39.53 & 0.79 & 1.97 & 1.20 & 3.68 & 2.44 \\
\hline Pinus rigida & 22.89 & 9.36 & 2.00 & 3.00 & 1.47 & 6.67 & 9.00 & 34.88 & 0.78 & 1.97 & 1.06 & 3.63 & 2.34 \\
\hline Quercus rubrum & 16.99 & 11.81 & 2.45 & 2.95 & 1.30 & 10.00 & 16.00 & 46.51 & 0.66 & 3.49 & 1.41 & 3.04 & 2.23 \\
\hline Sassafras albidum & 7.42 & 6.30 & 3.42 & 3.04 & 1.71 & 4.17 & 16.00 & 55.81 & 0.12 & 3.49 & 1.69 & 0.55 & 1.12 \\
\hline Rhododendron catawbiense & 3.93 & 2.96 & 3.89 & 2.11 & 1.07 & 0.00 & 8.00 & 62.79 & 0.03 & 1.75 & 1.91 & 0.16 & 1.03 \\
\hline Carya spp. & 14.35 & 11.64 & 3.20 & 2.20 & 1.20 & 0.00 & 5.00 & 23.26 & 0.29 & 1.09 & 0.71 & 1.35 & 1.03 \\
\hline Tsuga canadensis & 6.35 & 4.43 & 3.57 & 2.26 & 1.57 & 0.00 & 8.00 & 53.49 & 0.08 & 1.75 & 1.62 & 0.37 & 1.00 \\
\hline Kalmia latifolia & 3.10 & 2.44 & 4.00 & 2.38 & 1.44 & 0.00 & 12.00 & 37.21 & 0.01 & 2.62 & 1.13 & 0.06 & 0.59 \\
\hline Betula lenta & 4.23 & 3.57 & 3.50 & 3.64 & 1.29 & 21.43 & 9.00 & 32.56 & 0.03 & 1.97 & 0.99 & 0.12 & 0.55 \\
\hline Hamamelis virginiana & 3.16 & 3.33 & 3.79 & 3.14 & 1.36 & 14.29 & 7.00 & 32.56 & 0.01 & 1.53 & 0.99 & 0.05 & 0.52 \\
\hline Magnolia fraseri & 7.95 & 8.16 & 3.60 & 2.00 & 1.00 & 0.00 & 4.00 & 23.26 & 0.07 & 0.87 & 0.71 & 0.32 & 0.51 \\
\hline Amelanchier arborea & 4.80 & 3.60 & 2.90 & 2.10 & 1.10 & 0.00 & 3.00 & 23.26 & 0.02 & 0.66 & 0.71 & 0.09 & 0.40 \\
\hline Ilex opaca & 3.18 & 2.77 & 3.90 & 2.80 & 1.70 & 0.00 & 10.00 & 23.26 & 0.01 & 2.18 & 0.71 & 0.04 & 0.37 \\
\hline Rhododendron maximum & 4.06 & 2.78 & 4.00 & 2.00 & 1.00 & 0.00 & 1.00 & 9.30 & 0.01 & 0.22 & 0.28 & 0.02 & 0.15 \\
\hline Fagus grandifolia & 2.79 & 2.65 & 3.50 & 4.00 & 2.50 & 0.00 & 2.00 & 4.65 & 0.00 & 0.44 & 0.14 & 0.01 & 0.07 \\
\hline Cercis canadensis & 7.37 & 3.05 & 3.00 & 2.00 & 1.00 & 0.00 & 1.00 & 2.33 & 0.00 & 0.22 & 0.07 & 0.02 & 0.05 \\
\hline Cornus florida & 7.11 & 6.10 & 4.00 & 2.00 & 1.00 & 0.00 & 1.00 & 2.33 & 0.00 & 0.22 & 0.07 & 0.02 & 0.04 \\
\hline Liriodendron tulipifera & 2.54 & 4.61 & 4.00 & 3.00 & 2.00 & 0.00 & 1.00 & 2.33 & 0.00 & 0.22 & 0.07 & 0.00 & 0.04 \\
\hline
\end{tabular}

Table 4: Overstory species present in the rimrock forest with descriptive variables. Crown Class: $1=$ dominant, $2=$ codominant, $3=$ intermediate, $4=$ overtopped; Vigor: $1=$ healthy crown, $2=$ minor dieback, $3=$ some dieback but $>50 \%$ alive, $4=>50 \%$ of crown dead with some live branches, $5=$ crown completely dead with some stem and basal sprouts, 6 = crown completely dead with some basal sprouts, $7=$ dead tree; Longevity: $1=>20$ yrs to live (for vigor ratings 1 and 2 ), $2=10-20$ yrs to live (for vigor ratings 3 and 4 ), $3=<10$ yrs to live (for vigor ratings 5 and 6); Importance Value $=($ relative density + relative dominance) $/ 2$. 


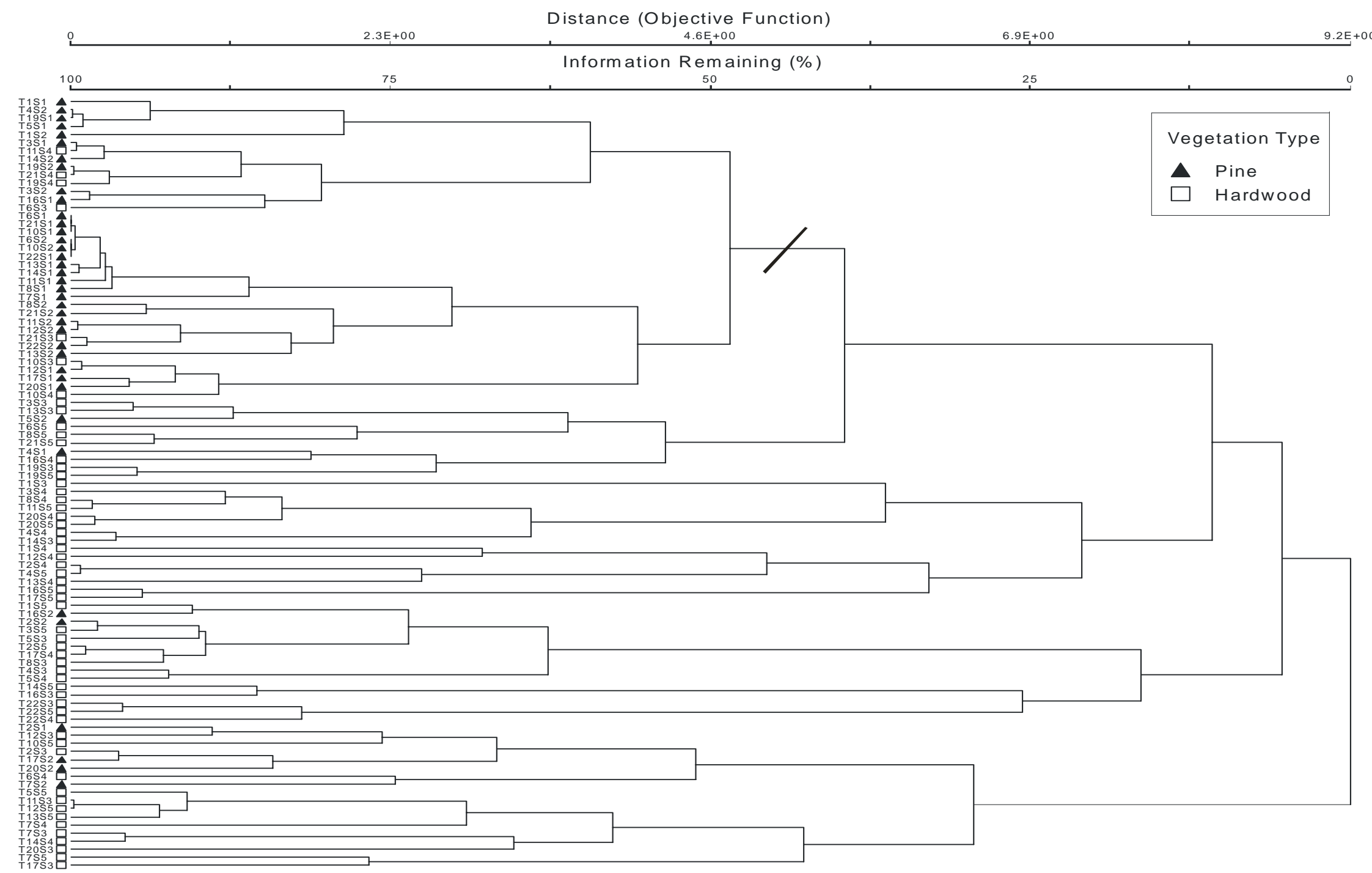

Figure 9: Cluster analysis of $8510 \times 6 \mathrm{~m}$ transect sections using overstory tree (DBH $>2.54 \mathrm{~cm}$ ) species IV as input data. Each section is labeled on the left and subjectively identified as either pine (solid triangle) or hardwood (open square). The diagonal line shows the separation between groups. Sorenson distance was the distance measure and sections were linked using the farthest neighbor method. 


\subsection{Understory Vegetation}

\subsubsection{Understory Structure and Composition}

The understory regeneration of the rimrock pine forest type was dominated by Acer rubrum, Sassafras albidum, Nyssa sylvatica, Oxydendrum arboreum, Pinus virginiana, and Quercus spp. of varying size classes. The germinal class was 55\% A. rubrum, $17 \%$ Quercus spp., $8 \%$ Hamamelis virginiana, and 2-3\% each for O. arboreum, $N$. sylvatica, and $P$. Virginiana (Fig. 10). The most abundant saplings in the "1 year+ but not established" class were S. albidum (39\%), A. rubrum (23\%), and Quercus spp. (14\%). Though red maple (29\%) was the most prevalent species in the "established" class, a substantial percentage of $P$. virginiana (13\%) and N. sylvatica $(9 \%)$ saplings were present.

Pinus virginiana regeneration was present in $38 \%$ of plots ( 25 of 66 ) with a density of approximately 4,200 stems/ha compared to A. rubrum presence in $78 \%$ of plots and a density of approximately 30,000 stems/ha (Table 5). Nearly half of the $P$. virginiana regeneration was found in the pine plots located at $5 \mathrm{~m}$ from the cliff edge.

Greenbrier, blueberry, mountain laurel, and rhododendron were present in $97 \%, 57 \%$, $62 \%$, and $17 \%$ of plots, respectively (Fig. 11). The pine plots had abundant amounts of Vaccinium pallidum (lowbush blueberry) between $15 \mathrm{~cm}-1.23 \mathrm{~m}$ in height with lesser amounts of Smilax rotundifolia (common greenbrier). In the ecotone and hardwood plots, Kalmia latifolia and Rhododendron catawbiense were common, covering $28-64 \%$ of plot area, with substantial amounts of greenbrier (16-50\% of plot area) as well.

Percent herbaceous cover for plot locations averaged $11 \%, 10 \%, 6 \%$ for the pine, ecotone, and hardwood plots, respectively. While the percent of herbaceous cover was similar for these locations on average, bare soil and rock was common in the pine plots and leaf litter 
was common in the ecotone and hardwood plots. Noted species included teaberry (Gaultheria procumbens), spotted wintergreen (Climaphila maculate), pink lady's slipper (Cypripedium acaule), and several unidentified grass species.

\subsubsection{Understory Grouping}

An understory cluster analysis was conducted to separate circular plots into pine (plot 1) and hardwood (plots 2 and 3) groupings. These groupings were subjectively defined and based on field observations and preliminary data analysis. The resulting dendrogram (Fig. 12) showed groupings of understory plots with a greater percentage of chaining $(14.04 \%)$ than the overstory transect sections. Understory plots clustered into 4 larger groups composed of 25-m and 45-m hardwood plots and 9 of 20 pine plots. Eleven pine plots clustered into smaller groups of two or three plots without forming a larger cohesive group. The MRPP results confirm the lack of pine and hardwood grouping despite a negative $T$-statistic $(T=-8.066)$ that was highly significant $(\mathrm{p}$ $<0.001)$. Average distance for the 20 pine plots was large (0.818). The A-statistic was low $(\mathrm{A}=$ 0.042) for studies of community ecology (McCune et al. 2002). 


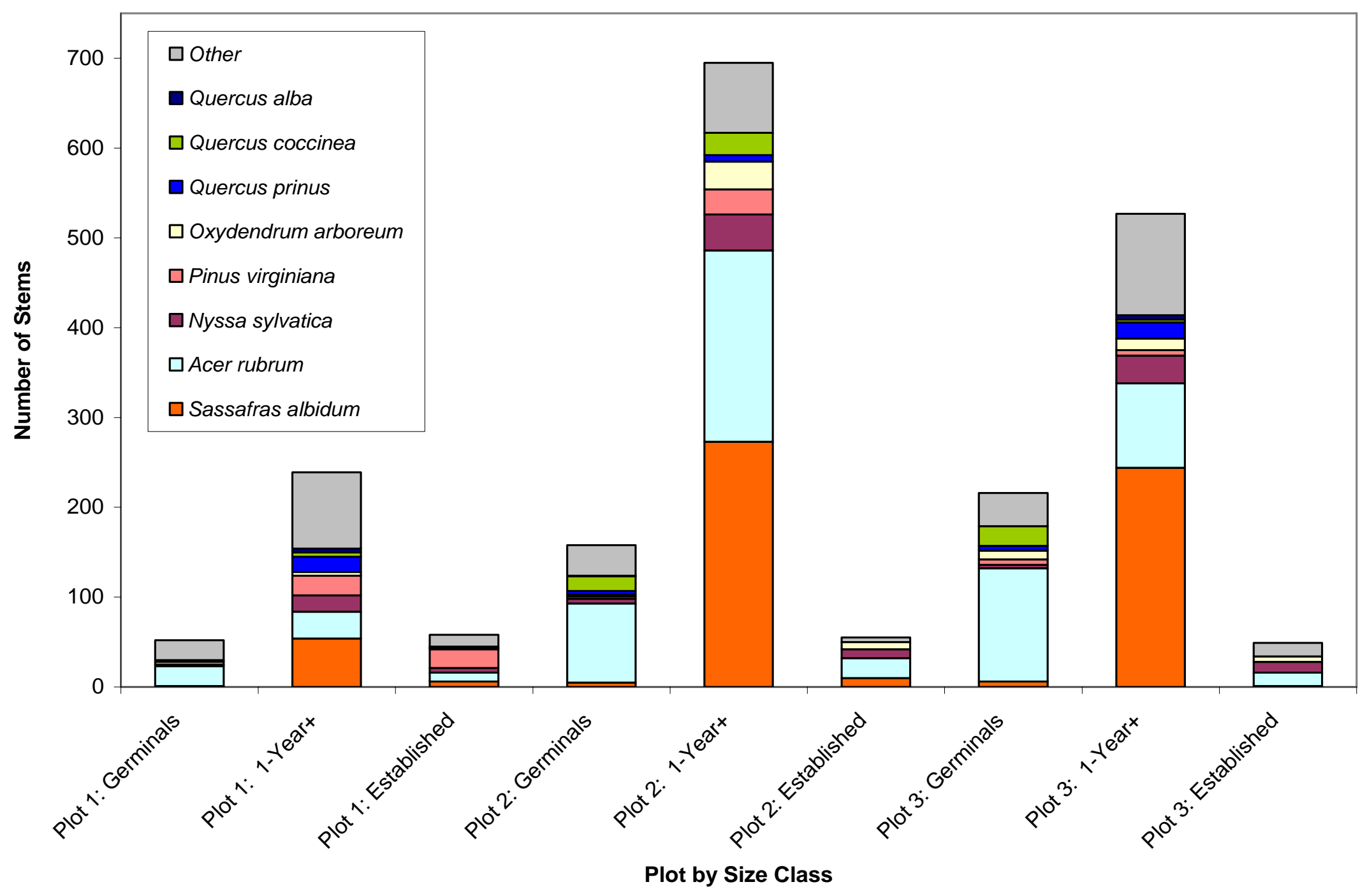

Figure 10: Number of understory stems by species for each plot and size class. Plot locations were $5 \mathrm{~m}$ (plot 1), $25 \mathrm{~m}$ (plot 2), and $45 \mathrm{~m}$ (plot 3 ) from cliff edge. Size classes were: 1) germinals $(<15 \mathrm{~cm}), 2) 1$ year+ but not established $(15 \mathrm{~cm}-1.23 \mathrm{~m})$, or 3$)$ established $(>1.23 \mathrm{~m} /<2.54 \mathrm{~cm} \mathrm{DBH})$. 


\begin{tabular}{|c|c|c|c|c|c|}
\hline Species & $\begin{array}{l}\text { Frequency } \\
\text { (\# sections) }\end{array}$ & $\begin{array}{c}\text { Density } \\
\text { (Stems/ha) }\end{array}$ & $\begin{array}{c}\text { Relative } \\
\text { Frequency }\end{array}$ & $\begin{array}{l}\text { Relative } \\
\text { Density }\end{array}$ & $\begin{array}{c}\text { Importance } \\
\text { Value }\end{array}$ \\
\hline Acer rubrum & 51 & 29917.00 & 14.53 & 30.24 & 22.39 \\
\hline Sassafras albidum & 52 & 28951.94 & 14.81 & 29.27 & 22.04 \\
\hline Nyssa sylvatica & 38 & 6031.65 & 10.83 & 6.10 & 8.46 \\
\hline Oxydendrum arboreum & 31 & 3763.75 & 8.83 & 3.80 & 6.32 \\
\hline Pinus virginiana & 25 & 4246.28 & 7.12 & 4.29 & 5.71 \\
\hline Quercus rubra & 20 & 4487.55 & 5.70 & 4.54 & 5.12 \\
\hline Quercus coccinea & 21 & 3570.74 & 5.98 & 3.61 & 4.80 \\
\hline Quercus velutina & 21 & 3136.46 & 5.98 & 3.17 & 4.58 \\
\hline Quercus prinus & 19 & 2509.17 & 5.41 & 2.54 & 3.97 \\
\hline Hamamelis virginiana & 10 & 2653.93 & 2.85 & 2.68 & 2.77 \\
\hline Magnolia fraseri & 12 & 1302.84 & 3.42 & 1.32 & 2.37 \\
\hline Viburnum acerifolium & 5 & 3136.46 & 1.42 & 3.17 & 2.30 \\
\hline Amelanchier arborea & 7 & 1302.84 & 1.99 & 1.32 & 1.66 \\
\hline Ilex ораса & 8 & 530.79 & 2.28 & 0.54 & 1.41 \\
\hline Carya spp. & 6 & 965.06 & 1.71 & 0.98 & 1.34 \\
\hline Betula lenta & 6 & 723.80 & 1.71 & 0.73 & 1.22 \\
\hline Quercus alba & 5 & 482.53 & 1.42 & 0.49 & 0.96 \\
\hline Lonicera spp. & 2 & 434.28 & 0.57 & 0.44 & 0.50 \\
\hline Fagus grandifolia & 3 & 144.76 & 0.85 & 0.15 & 0.50 \\
\hline Liriodendron tulipifera & 2 & 193.01 & 0.57 & 0.20 & 0.38 \\
\hline Magnolia acuminata & 2 & 96.51 & 0.57 & 0.10 & 0.33 \\
\hline Castanea dentata & 1 & 96.51 & 0.28 & 0.10 & 0.19 \\
\hline Robinia pseudoacacia & 1 & 96.51 & 0.28 & 0.10 & 0.19 \\
\hline Cercis canadensis & 1 & 48.25 & 0.28 & 0.05 & 0.17 \\
\hline Cornus florida & 1 & 48.25 & 0.28 & 0.05 & 0.17 \\
\hline Tsuga canadensis & 1 & 48.25 & 0.28 & 0.05 & 0.17 \\
\hline
\end{tabular}

Table 5: Understory species present in the sample transects with descriptive variables. Importance values were calculated as one-half the sum of the relative frequency and relative density. 


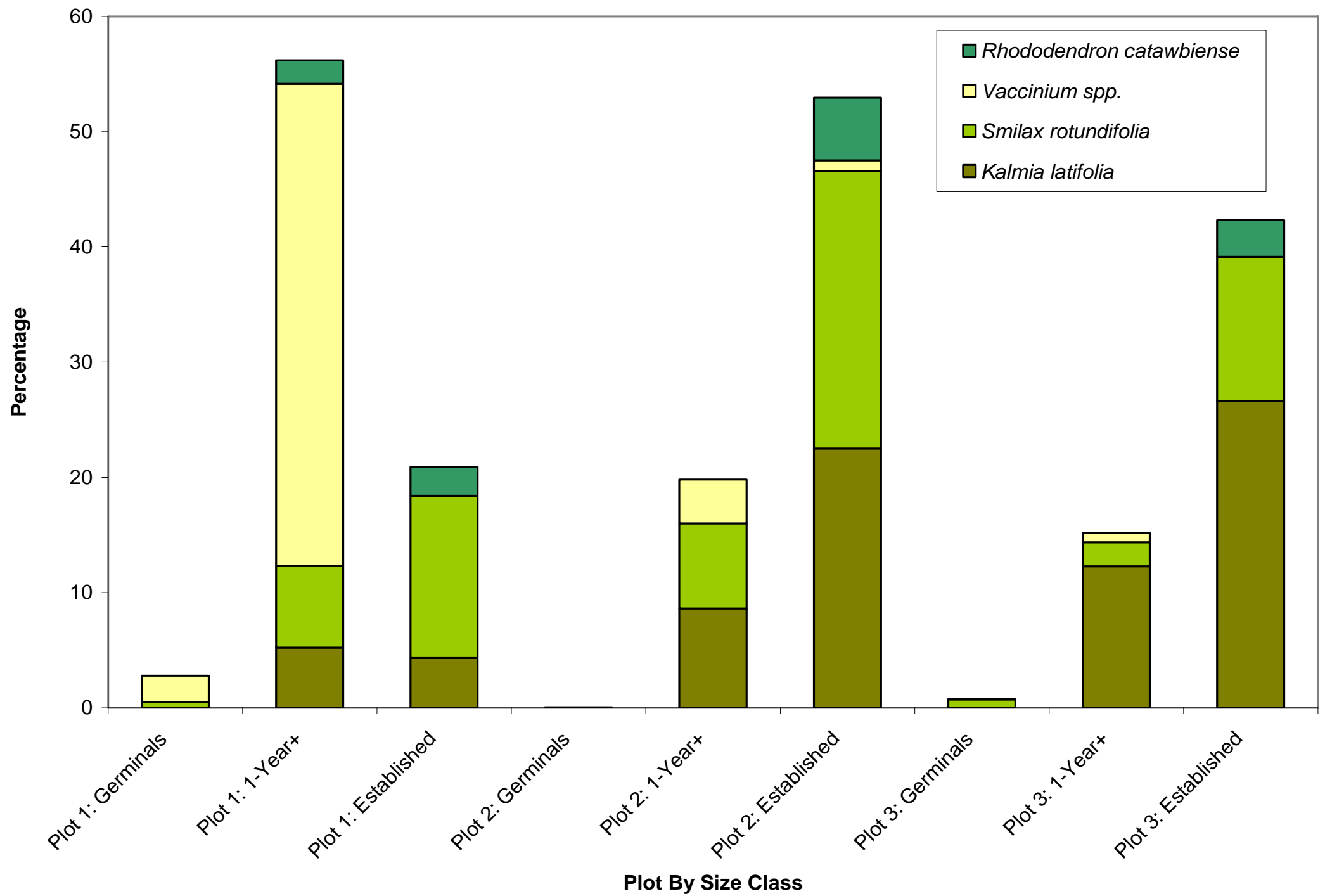

Figure 11: Percentage of shrub cover in understory plots by species for each plot location (based on distance from the cliff edge) and size class. 


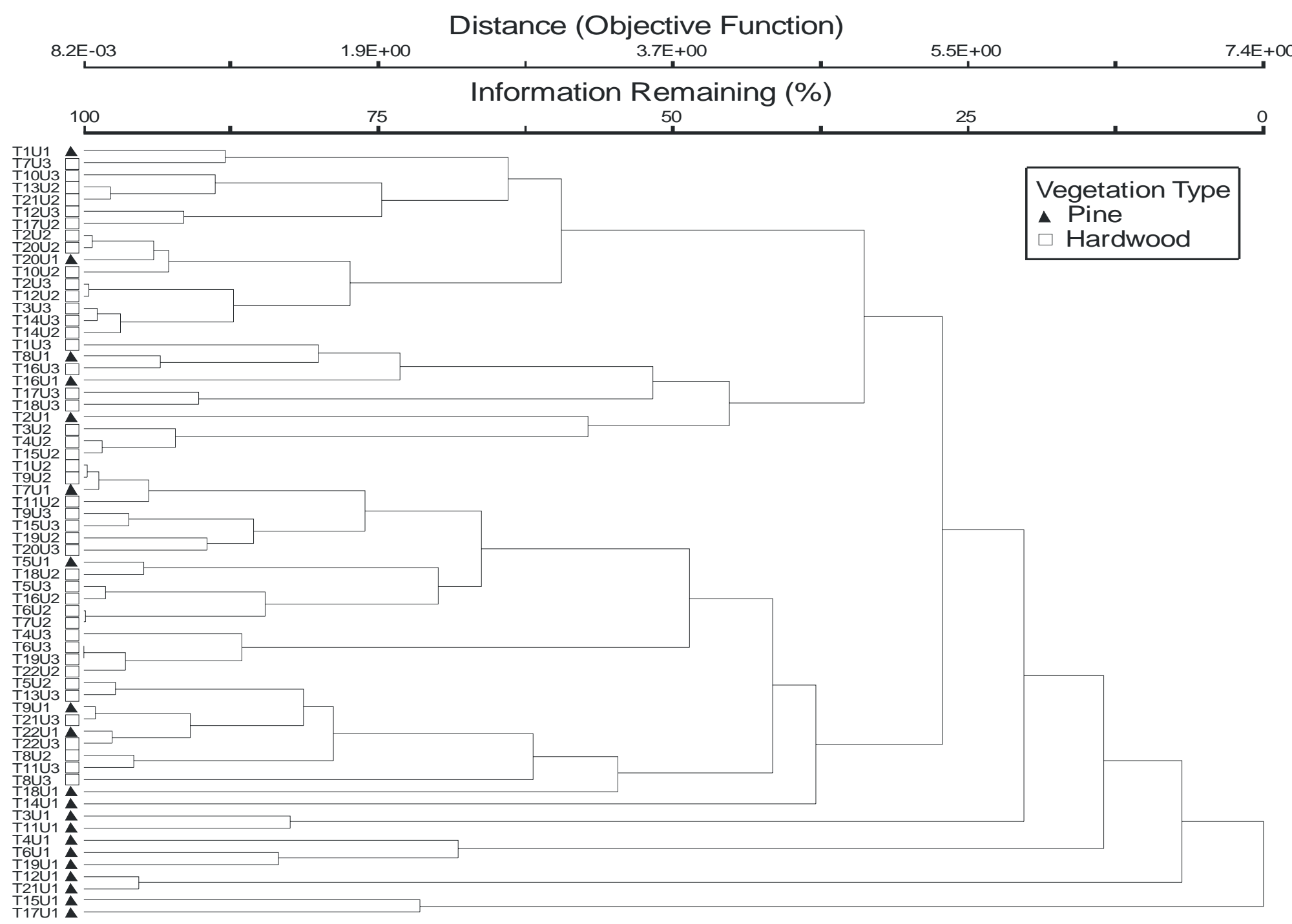

Figure 12: Cluster analysis of 64 understory plots using understory woody vegetation (DBH $<2.54 \mathrm{~cm}$ ) species IV as input data. Each plot is labeled on the left and subjectively identified as either pine (solid triangle) or hardwood (open square). Sorenson distance was the distance measure and sections were linked using the farthest neighbor method. 


\subsection{Age Structure and Growth Trends}

Pinus rigida was the largest diameter and oldest species on the rimrock site with establishment dates of 1830, 1840, and 1861 for cored trees (Fig. 13). The oldest Pinus virginiana established in 1900 , and two periods of $P$. virginiana establishment were noted in between the periods 1900-1909 and 1943-1946. Similar periods of establishment for the Quercus spp. were observed, however, the largest and oldest oak established in 1861. A lack of establishment was seen for the period of 1911-1937 for all species. Then, small diameter, shade tolerant species (i.e., Acer rubrum, Nyssa sylvatica, and Oxydendrum arboreum) invaded the understory in the 1940s and early 1950s. It is important to note that only surviving stems were sampled. Therefore, the diameter-age distribution in Figure 13 does not depict earlier successional species that may have established during the 1911-1937 period and were subsequently killed by fire, logging, or competition prior to sampling.

The master chronologies developed for pine, oak, and maple show highly variable growth rates over time (Figs. 14, 15, and 16). For each chronology, the standardized ring-width indices had mean value of one. Periods of above-average growth occurred when the index rose above one while periods of below average growth occurred when the index fell below one. Using the criteria of Nowacki and Abrams (1997), growth releases were calculated from raw ring-widths for pine and oak species. Four pines experienced minor releases in 1939, 1964, 1971, and a major release in 1923. Two oaks recorded 2 minor releases in 1925 and 1964. 


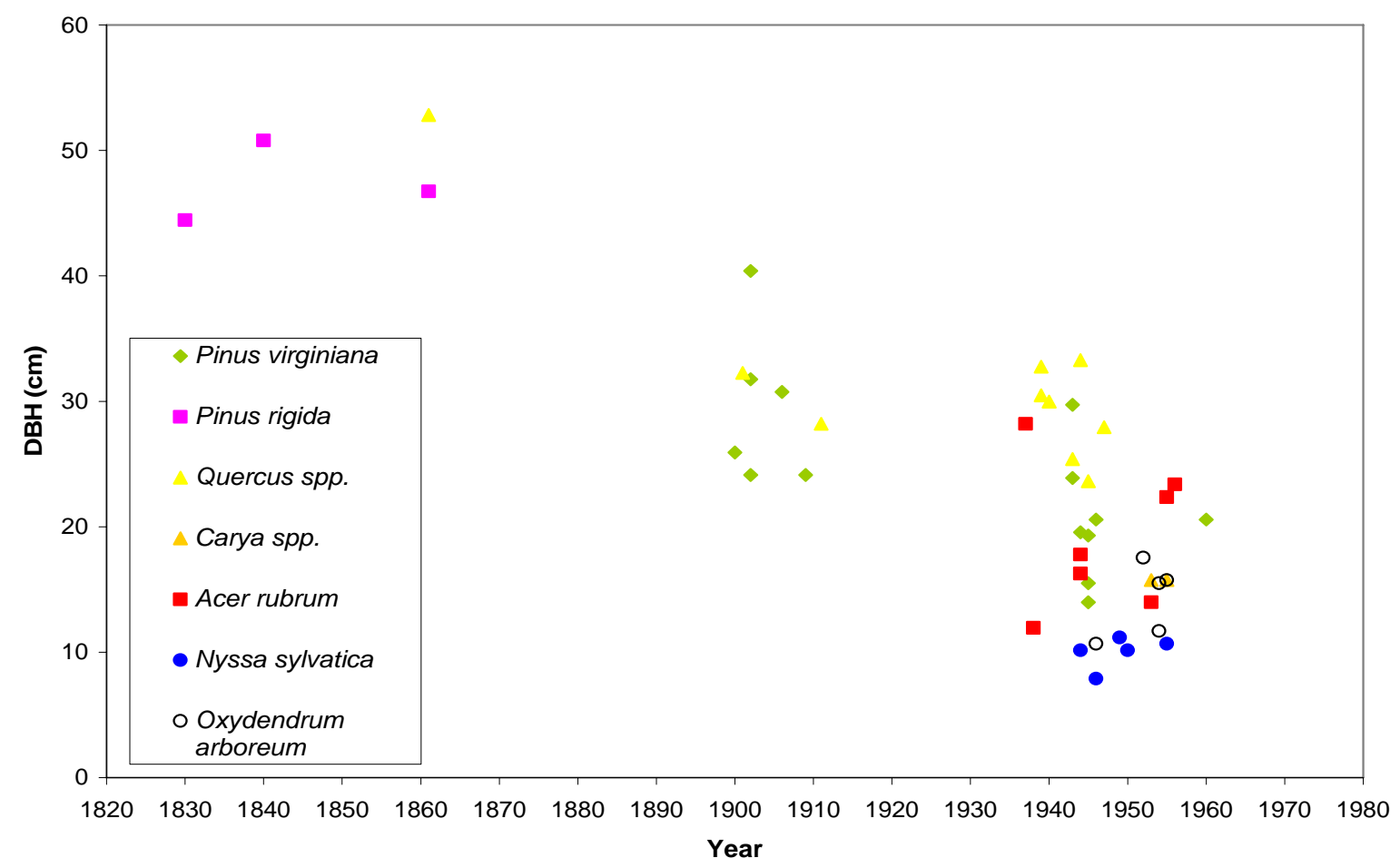

Figure 13: Age-diameter distribution of species sampled along the "Endless Wall" in New River Gorge National River, WV.

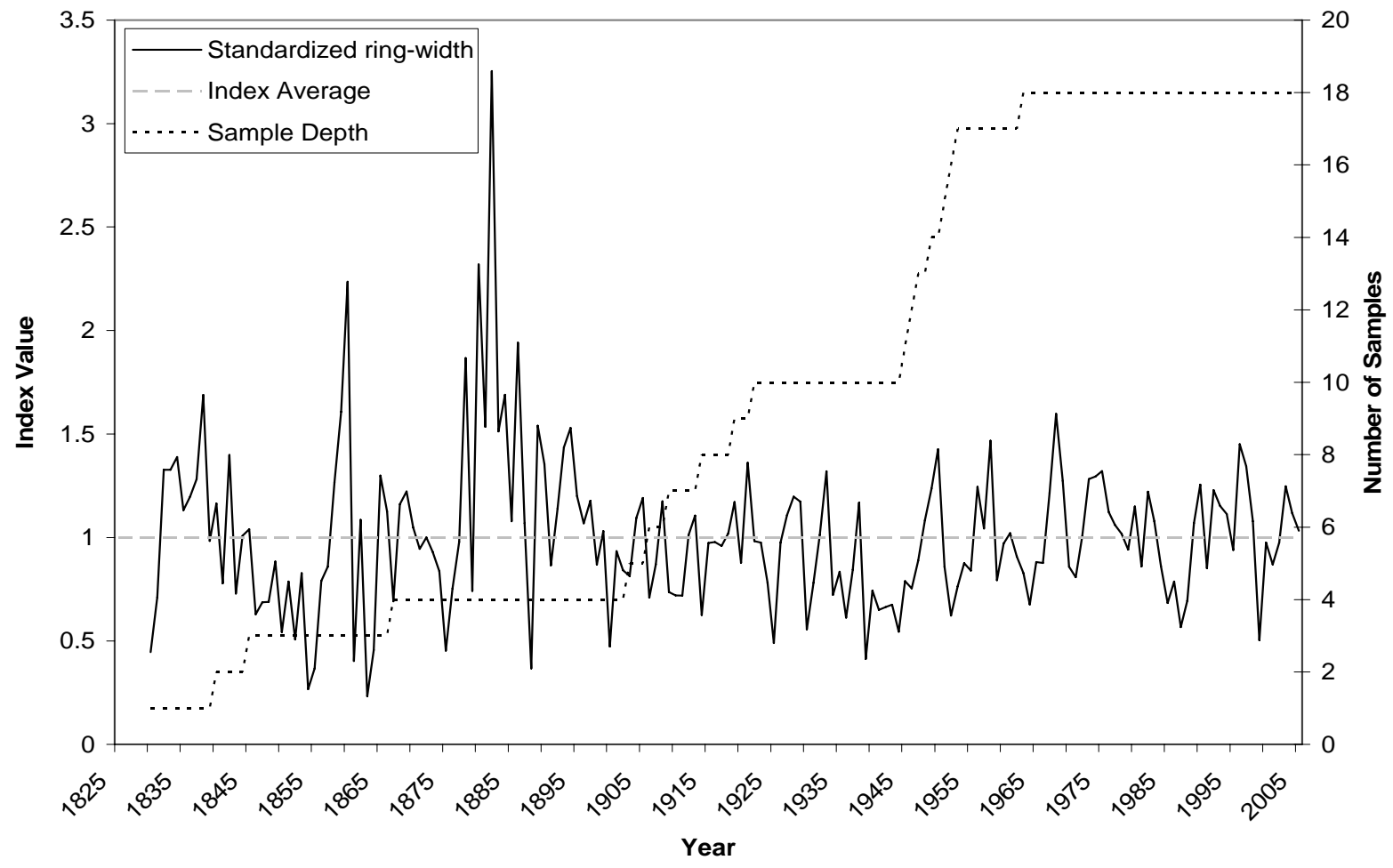

Figure 14: Master chronology for Pinus species (N=18). 


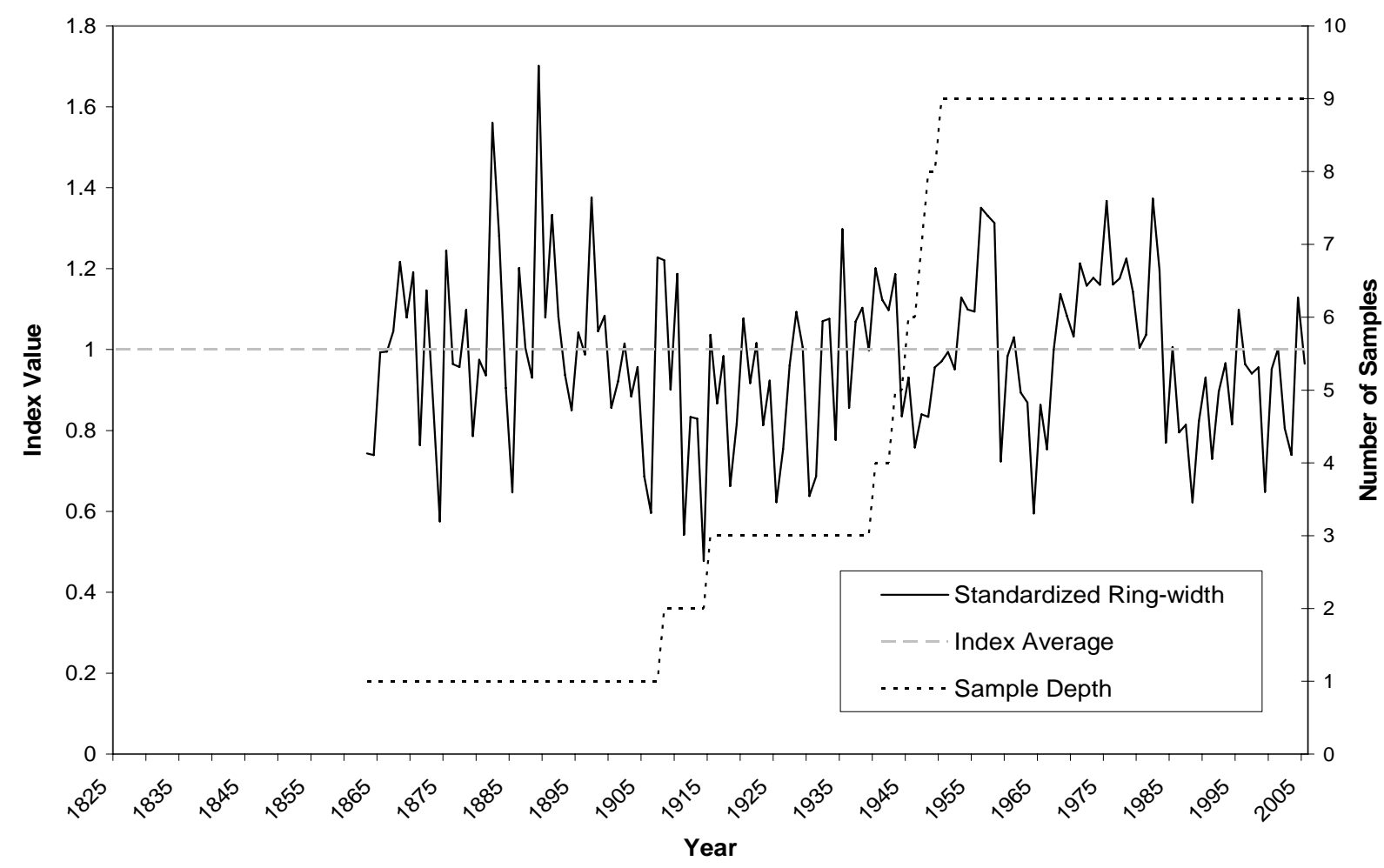

Figure 15: Master chronology for Quercus species (N=9).

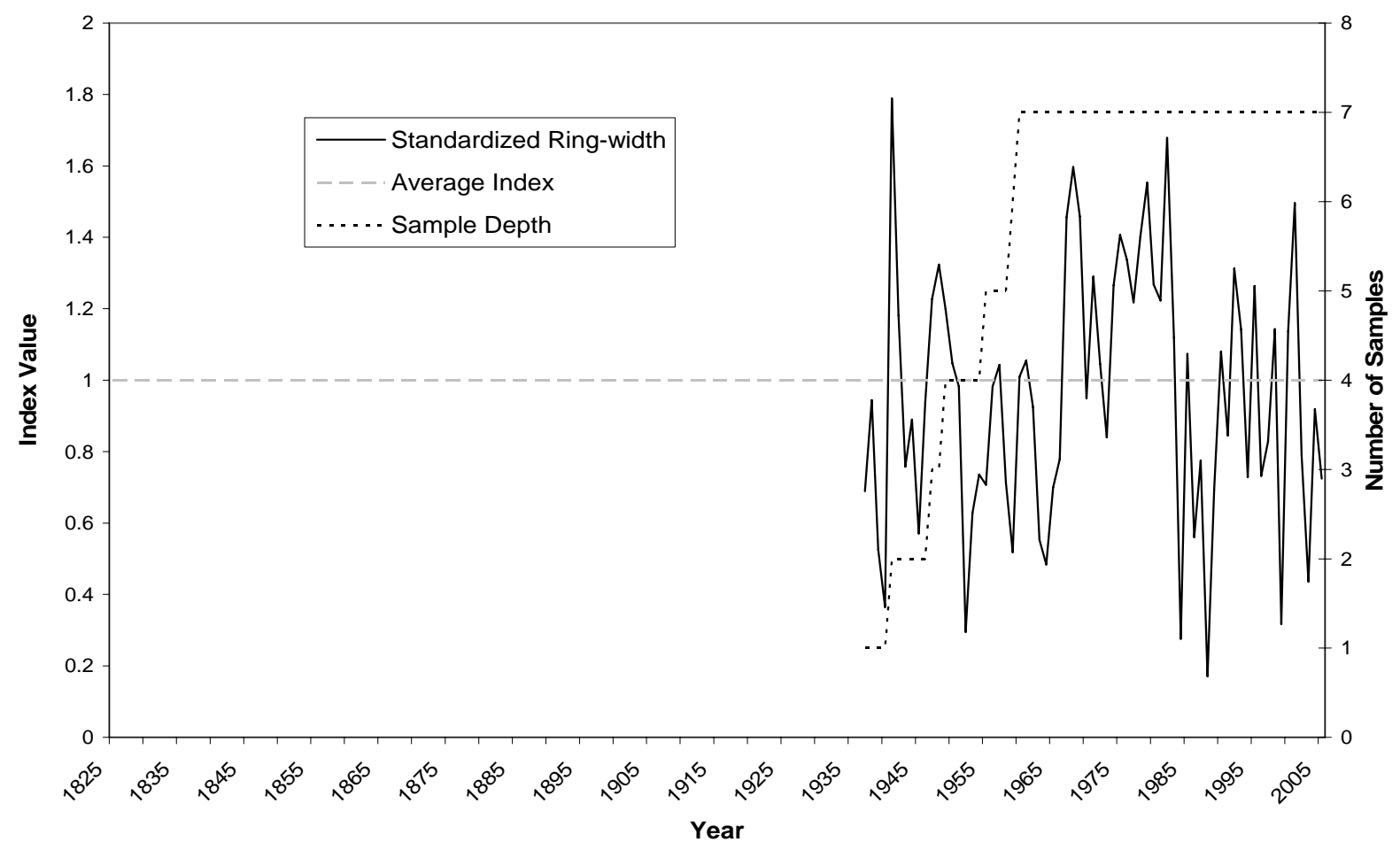

Figure 16: Master chronology for Acer rubrum (N=7). 


\subsection{Fire History}

A 108-year fire chronology (1897-2005) was constructed from 51 fire scars recorded by 23 trees along the "Endless Wall" in New River Gorge National River, West Virginia (Fig. 17). Forty-eight of these fires occurred in the dormant season and seasonality was undetermined for the remaining 3 fires. Pith dates from cross sections ranged from 1897 to 1961 . Origin dates could not be established on 2 cross sections due to decay. Fires were detected by at least one sample in 1914, 1922, 1930, 1932, 1934, 1938, 1939, 1940, 1941, 1945, 1946, 1948, 1952, 1953, 1954, 1956, 1963, 1965, 1970, 1972, and 1976 (Table 6). The largest fires ( $\geq 5$ fire-scarred trees) occurred in 1938, 1946, 1953, and 1970. It must be noted that, due to the young age of some sample trees, dating of cross sections may be inaccurate. Error in crossdating may have the effect of increasing the number of fire intervals reported in the composite chronology; however, fire intervals within each sample remain accurate. Median point fire interval values ranged from 3.5 to 5.5 years with minimum and maximum values of 1 and 9 years for two sites, respectively (Fig. 18). These values may be taken as point estimates of fire frequency. Other injuries from unknown sources occurred in 1940, 1943, 1944, 1953, 1954, 1957, 1966, 1983, 1989, 1990, 1993, 1997, 1998, and 2002, and were not used in the fire interval analysis.

Fire interval data for each site was analyzed separately prior to performing a stand-wide analysis. Six cross sections were collected from the Fern Creek site and 8 fire intervals were recorded in the site chronology. Using a liberal criterion (at least 1 tree recording a fire event), the K-S test indicated that the fire intervals could be described by either the empirical $(\mathrm{p}=0.957)$ or Weibull $(\mathrm{p}=.951)$ distributions. Schuler and McClain (2003) noted that the K-S test lacks robustness when the number of intervals being evaluated is small; therefore, the empirical and Weibull summary statistics are reported for each site (Tables 7, 8, and 9). Both distributions 
yielded about a 4 year return interval for the Fern Creek site. The Weibull exceedance probabilities of 0.875 and 0.125 indicated that fire intervals were unusual when less than 1.5 years and greater than 8 years occurred between fires, respectively. A conservative criterion (at least 2 trees recording a fire event) was not used to evaluate the intervals between fires for the Fern Creek site due to the small sample size.

Seventeen trees were sampled from the Short Creek site and 16 fire intervals were recorded in the site chronology using the liberal criterion (Table 8). The K-S test indicated that both the empirical $(p=0.241)$ and Weibull $(p=0.554)$ distributions adequately described the intervals between fires with mean and median values between 3.5 and 4 years. Using at least two recorder trees to define a fire event, the K-S test returned p-values of 0.964 and 0.992 for the empirical and Weibull distributions, respectively. The Weibull median fire interval (WMFI) was 7.7 years for the conservative analysis and lower and upper exceedance values were 3.6 years and 12.6 years. The mean fire interval (MFI) was 8 years. The MFI and WMFI both increased by approximately 4 years using the conservative criterion.

When data from the two sites were combined, the empirical distribution did not adequately model the intervals between fires for either criterion (Table 9). Fire intervals from the stand-wide fire chronology ranged from 1 to 14 years when using two or more trees as an indicator of a past fire. The WMFI and MFI were 3.2 and 4.2 years, respectively. The 1970 fire resulted in the greatest percentage of fire-scarred trees (43\%) with evidence from both sites. Because an interval must be bounded by two fires, the 29-year fire-free period from 1976-2005 was not included in the calculation of fire intervals. However, this period was not characteristic of the period modeled from 1897-2005. 


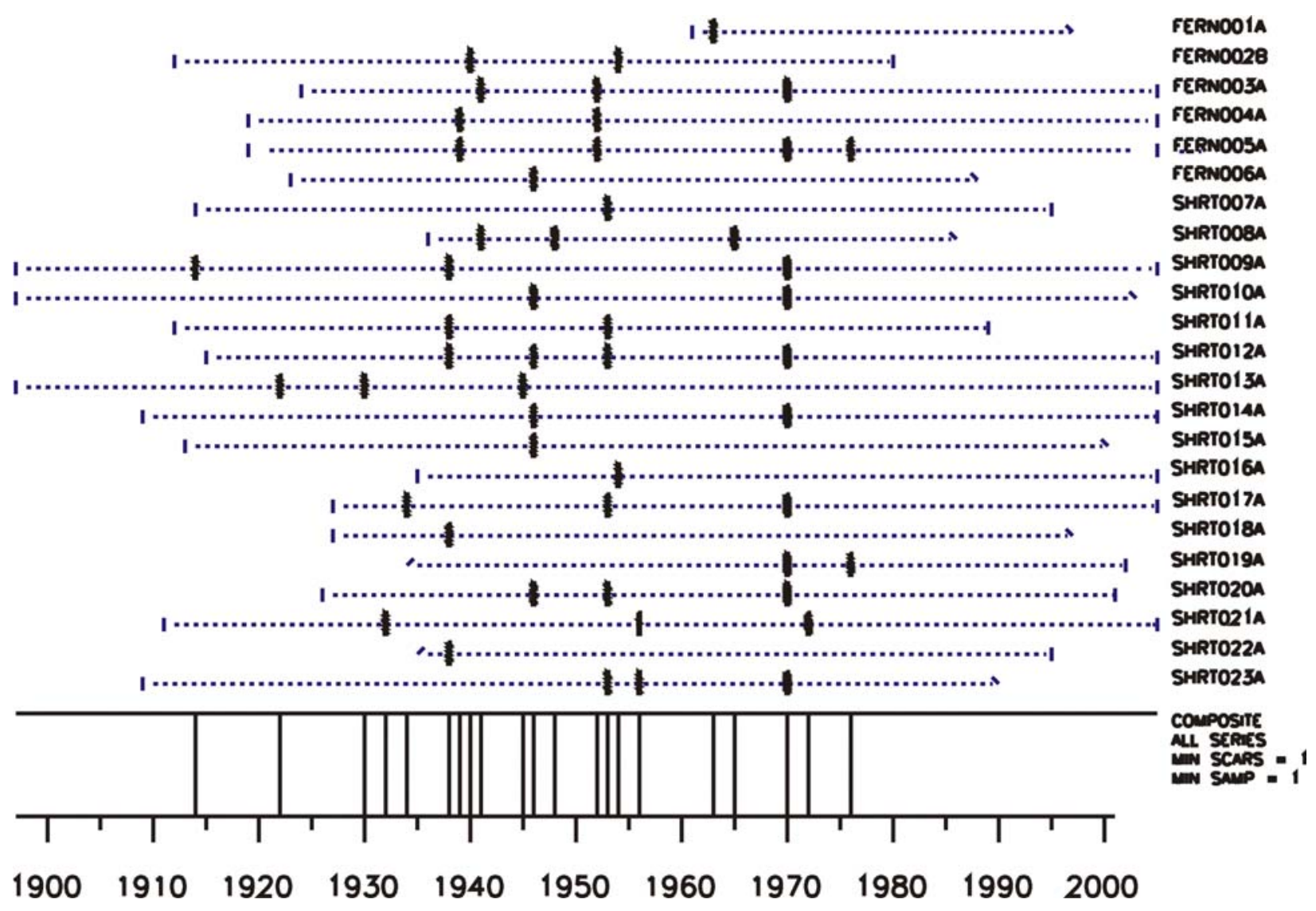

Figure 17: Fire scar chronology from 22 Virginia pines and 1 pitch pine cut from the "Endless Wall" in the northern section of New River Gorge National River, West Virginia. Each horizontal line (dashed) represents the annual rings of one sample cross section. Vertical lines represent pith dates (left) or outer ring dates (right). Forward slashes represent earliest dated annual rings when pith was not present. Back slashes represent outermost ring of samples without bark. Bold vertical bars represent fire events. 


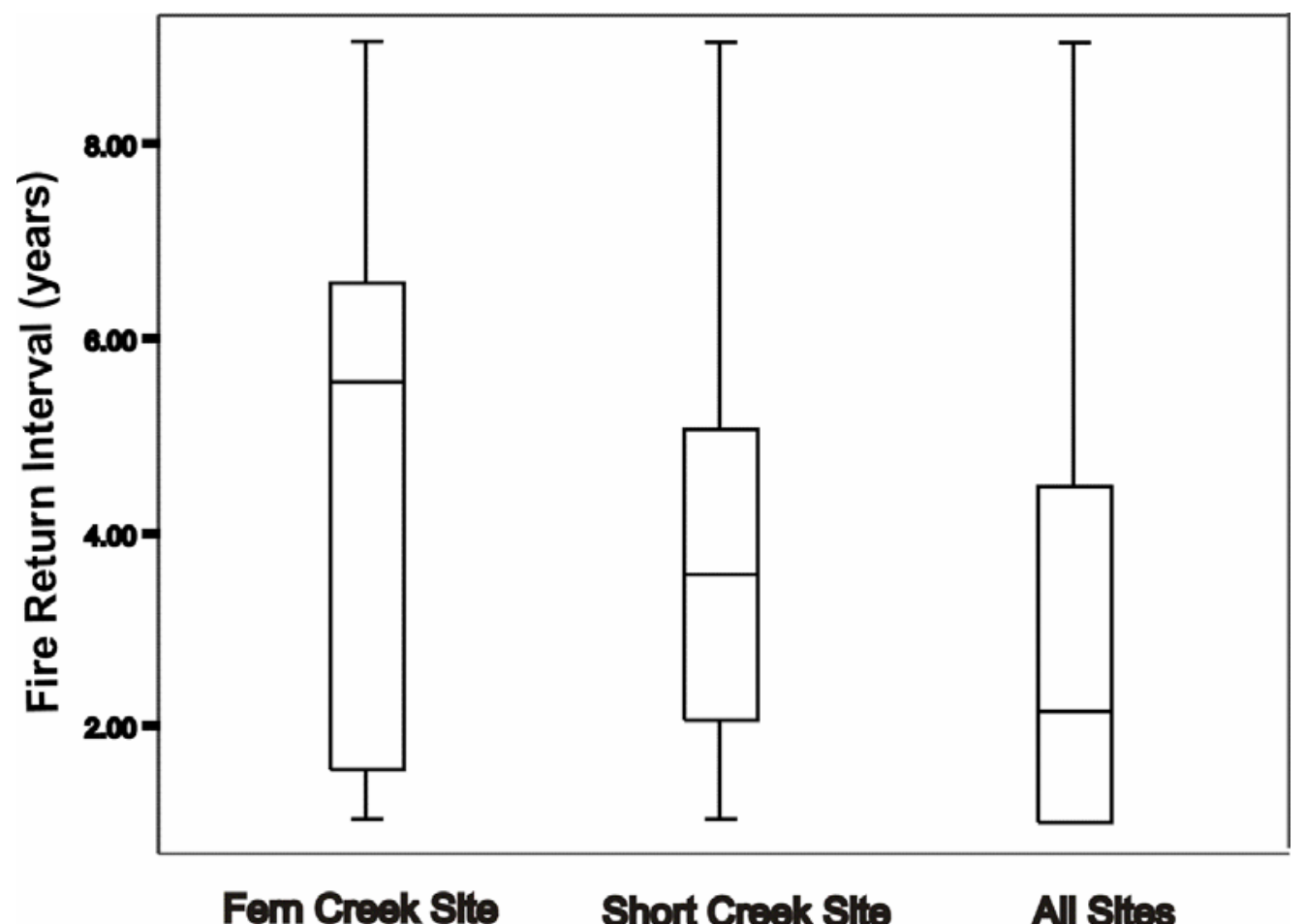

Figure 18: Fire return interval boxplots for Fern Creek, Short Creek, and both sites combined. Boxplots include median, quartiles, and minimum and maximum return intervals. 


\begin{tabular}{rrrr}
\hline Year & Sample depth & Total fire scars & Fire interval \\
\hline 1914 & 9 & 1 & 0 \\
1922 & 12 & 1 & 8 \\
1930 & 18 & 1 & 8 \\
1932 & 18 & 1 & 2 \\
1934 & 19 & 1 & 2 \\
1938 & 22 & 5 & 4 \\
1939 & 22 & 2 & 1 \\
1940 & 22 & 1 & 1 \\
1941 & 22 & 2 & 1 \\
1945 & 22 & 1 & 1 \\
1946 & 22 & 6 & 2 \\
1948 & 22 & 1 & 1 \\
1952 & 22 & 3 & 1 \\
1953 & 22 & 6 & 1 \\
1954 & 22 & 2 & 1 \\
1956 & 22 & 2 & 4 \\
1963 & 23 & 1 & 1 \\
1965 & 23 & 1 & 2 \\
1970 & 23 & 10 & 1 \\
1972 & 23 & 1 & 6 \\
1976 & 23 & 2 & 2 \\
\hline
\end{tabular}

Table 6: Summary of fire information for both sites combined. Sample depth represents the number of trees present in the sample for the fire year. Fire intervals must be bounded by two fire events. There was no evidence of fire after 1976; however, several trees recorded scars from unknown sources following the last fire.

\begin{tabular}{lr}
\hline & Liberal criteria \\
\hline Total intervals & 8.00 \\
Mean fire interval (yrs) & 4.63 \\
Standard deviation (yrs) & 2.97 \\
Median fire interval (yrs) & 5.50 \\
Weibull modal interval (yrs) & 2.87 \\
Weibull median interval (yrs) & 4.11 \\
Weibull scale parameter & 5.15 \\
Weibull shape parameter & 1.63 \\
Minimum fire interval (yrs) & 1.00 \\
Maximum fire interval (yrs) & 9.00 \\
Empirical K-S & $0.181(\mathrm{p}=0.957)$ \\
Weibull K-S & $0.183(\mathrm{p}=0.951)$ \\
\hline
\end{tabular}

Table 7: Fire interval analysis for the Fern Creek site using a liberal criterion (at least 1 tree recording a fire event). A conservative analysis (at least 2 trees recording a fire event) was not used due to the small sample size. 


\begin{tabular}{lrr}
\hline & Liberal criteria & Conservative Criteria \\
\hline Total intervals & 16.00 & 4.00 \\
Mean fire interval (yrs) & 3.88 & 8.00 \\
Standard deviation (yrs) & 2.55 & 4.55 \\
Median fire interval (yrs) & 3.50 & 7.50 \\
Weibull modal interval (yrs) & 2.51 & 6.84 \\
Weibull median interval (yrs) & 3.50 & 7.66 \\
Weibull scale parameter & 4.36 & 9.07 \\
Weibull shape parameter & 1.66 & 2.18 \\
Minimum fire interval (yrs) & 1.00 & 3.00 \\
Maximum fire interval (yrs) & 9.00 & 14.00 \\
Empirical K-S & $0.257(\mathrm{p}=0.241)$ & $0.250(\mathrm{p}=0.964)$ \\
Weibull K-S & $0.199(\mathrm{p}=0.554)$ & $0.217(\mathrm{p}=0.992)$ \\
\hline
\end{tabular}

Table 8: Fire interval analysis for the Short Creek site using liberal (at least 1 tree recording a fire event) and conservative (at least 2 trees recording a fire event) criteria.

\begin{tabular}{lrr}
\hline & Liberal criteria & Conservative Criteria \\
\hline Total intervals & 20.00 & 9.00 \\
Mean fire interval (yrs) & 3.10 & 4.22 \\
Standard deviation (yrs) & 2.34 & 4.24 \\
Median fire interval (yrs) & 2.00 & 2.00 \\
Weibull modal interval (yrs) & 1.55 & 0.68 \\
Weibull median interval (yrs) & 2.68 & 3.21 \\
Weibull scale parameter & 3.45 & 4.44 \\
Weibull shape parameter & 1.46 & 1.13 \\
Minimum fire interval (yrs) & 1.00 & 1.00 \\
Maximum fire interval (yrs) & 8.00 & 14.00 \\
Empirical K-S & $0.350(\mathrm{p}=0.015)$ & $0.460(\mathrm{p}=0.044)$ \\
Weibull K-S & $0.236(\mathrm{p}=0.215)$ & $0.223(\mathrm{p}=0.764)$ \\
\hline
\end{tabular}

Table 9: Fire interval analysis for all sites using liberal (at least 1 tree recording a fire event) and conservative (at least 2 trees recording a fire event) criteria. 


\section{CHAPTER 5: DISCUSSION}

\subsection{Vegetation Classification}

The rimrock pine forest type is characterized by a canopy of Virginia pine, black gum, sourwood, red maple, and oak species. The importance of Virginia pine decreases as distance from the cliff edge increases. In fact, the frequency of Virginia pine decreases by at least $50 \%$ every $10 \mathrm{~m}$ until it becomes marginal at $40-50 \mathrm{~m}$. The cluster analysis of canopy species confirmed that the pine component was concentrated within the first $20 \mathrm{~m}$ from the cliff edge. However, suitable growing conditions exist up to $300 \mathrm{~m}$ from the cliff edge for drier, southfacing aspects which may explain the grouping of some pine and hardwood transect sections. Regeneration of Virginia pine is relatively sparse when compared to the number of stems/ha of competing deciduous species. Those stems surviving to the sapling size classes are suppressed under a closed canopy except for individuals established within the first $20 \mathrm{~m}$ from the cliff edge that may receive more direct light due to the southern exposure sparse canopy of Virginia pine.

The understory cluster analysis did not confirm the subjectively defined pine (5-m plots) and hardwood (25-m and 45-m plots) groupings. One explanation for the lack of clustering is the use of species IV as the input data for the analysis. This variable may not be suitable because it does not include a measure of un-vegetated areas (bare rock and soil) that were common in the 5-m plots. The understory shrub layer of the forest is dominated by greenbrier, blueberry, mountain laurel and rhododendron. The herbaceous layer is sparse within the first $10 \mathrm{~m}$ because of soil compaction and the presence of bare rock. Farther from the cliff edge, thick leaf litter may prevent herbs from growing in larger numbers.

These results confirm Vanderhorst's (2002) classification of the rimrock pine forest as a linear Virginia pine-(oak)/blackgum/teaberry forest when selectively sampling within the pine 
component. The species composition of this forest type is present within the first $20 \mathrm{~m}$ from the cliff edge with the dominant vegetation quickly changing to hardwood species after $20 \mathrm{~m}$. It is likely that the rimrock will become increasingly dominated by hardwood species except for the cliff edge and larger rock outcrops (e.g., Diamond Point) that receive direct sunlight throughout the day. In theses areas, Virginia pine is an edaphic climax species as evidenced by the harsh site conditions created by the soil type and orientation of the cliff face, the high density and low basal area of overstory pine, and continuous recruitment of pine saplings. Whittaker (1956) discussed the characteristics of climax theory and hypothesized that topographic and edaphic climaxes occurred in areas with a distinct soil parent-material, steepness of slope, and dryness as affected by direction of exposure. Throughout the Appalachian Mountains, edaphic pine (Abrams and Orwig 1995) and oak communities (Nowacki and Abrams 1991) have persisted due to site factors.

One issue of concern is the threat of decline due to the aging of Virginia pine in the canopy. Fenton and Bond (1964) reported an estimated longevity of 90 years for Virginia pine growing on poor sites in southern Maryland. Of the Virginia pines cored for the present study, half of the sample dated approximately 100 years old while the other half dated 60 years old. As mentioned above, understory sapling and seedling classes are dominated by hardwood species. Ohmand and Buell (1968) report that these size classes are the best indicator of future species composition in communities without disturbance. This suggests that the older cohort of dominant and codominant pines in the canopy will senesce in the next 10-15 years leaving a younger cohort to compete with a host of deciduous competitors established in the 1940s as well as the present hardwood regeneration (Fig. 4.7). Table Mountian pine communities located in the Ridge and Valley (Williams and Johnson 1990, Sutherland et al. 1993) and southern 
Appalachian (Zobel 1969, Harmon 1982) physiographic provinces are experiencing similar successional trends in the absence of fire.

\subsection{Disturbance Regime}

Virginia pine requires a disturbance, such as logging or fire, to regenerate (Fenton and Bond 1964, Carter and Snow 1990). These disturbances prepare the seedbed by exposing mineral soil and opening the canopy to provide direct sunlight for seedling establishment. In the present study, fires were found to occur every 1 to 9 years. This estimation of fire frequency is based on point fire return intervals at each site due to the small sample size and difficulty dating cross sections taken from dead pines. The Weibull median fire interval at each site was approximately 4 years when using one tree as an indicator of a past fire. Major fire events, injuring at least 5 trees, were recorded in 1938, 1946, 1953, and 1970. Despite the size of these major fires, the presence of a large number of fire-scarred survivors indicates low-intensity events (Romme 1980). Compared to other xeric forest types in the central Appalachians, fires occurred more frequently along the rimrock than in other areas. For instance, Schuler and McClain (2003) found a MFI of 15.5 years for red oak growing on a poor site in southeastern West Virginia and Sutherland and colleagues (1993) reported MFIs of 9 to 11 years for a Table Mountain pine stand in the Ridge and Valley province of southwestern Virginia.

A primary reason for the discrepancy in fire frequency between the rimrock pine communities of the New River Gorge and other forest types of the central Appalachians may be due to differences in past land use. In Appalachian mixed-oak forests, steam-driven locomotives and mining activities have been identified as potential ignition sources (Brose et al. 2001, Shumway et al. 2001). Brooks (1910) cited locomotives (71\%), saw mills and campers (20\%), improving rangeland (3\%), arson (2\%), and other causes (4\%) as ignition sources in West 
Virginia for the 1908 fire year. While natural fires caused by lightening do occur in the eastern United States, the majority of historic fires have been caused by human ignition sources (Abrams 1992). Fires in the New River Gorge would likely have been ignited by locomotives, mining activities, and land clearing. The operation of more than 150 mines and continuous traffic on the C\&O railroad running along the bottom of the gorge provided ample ignition sources. These ignitions would have produced fires that burned quickly up the slope of the gorge with increasing intensity and flame length. To reach the rimrock above the $15-35 \mathrm{~m}$ sandstone cliffs, the fire had to travel up vegetated gaps or ignite from burning debris landing on the top of the cliff. The presence of fire-scarred Virginia and pitch pine tells us that the fires were of low to moderate intensity once burning began along the rimrock community. The linear form of the rimrock pine forest may have allowed only small sections of the rimrock to burn during each event. This is evidenced by the greater number of short fire return intervals $(<2$ years $)$ calculated from the composite fire chronologies for the entire study area. A fire regime of this type would have allowed dominant pines to survive while creating patches of even-aged regeneration.

Studies of Table Mountain pine/Pitch pine stands in the southern Appalachian Mountains have found fire to be an important disturbance maintaining these xeric ridgetop communities (Brose and Waldrop 2000, Brose et al. 2002, Waldrop et al. 2003). In these studies, pine and oak dominated the canopy, more shade tolerant black gum and red maple occupied the midstory, and mountain laurel covered the majority of the understory. They found that major disturbances, presumably fire or logging, were followed by pulses of regeneration of pine and oak seedlings as well as increased radial growth of surviving Table Mountain pine. Based on the growth release criteria of Nowacki and Abrams (1997), pines and oaks in the present study did not experience any minor or major releases in the 1940 s or 1950s. However, a visual examination of the tree- 
ring index values from the pine and oak master chronologies show a trend of increased growth following major fire events. While precise dating of fire-scarred samples taken from dead trees was difficult, the occurrence of fire on the rimrock and the reaction to disturbance is evident. Frequent fires, throughout the 1940s and early 1950s, led to the establishment of a host of species following these disturbances. It could be argued that the regeneration during the period of 1937-1960 was caused by one stand-replacing fire occurring in the 1930s. This scenario is unlikely because a sufficient number of samples $(\mathrm{N}=18)$ were present during this time period and did not record such an extensive fire event. Also, historical records indicate that the period of pine and oak establishment from 1900-1910 was probably due to harvesting and fire. Brooks (1910) reported fire statistics for West Virginia citing 710 fires and 1.7 million acres burned in the fall season of 1908 .

More recent fire records from 1939-present were collected by the West Virginia Division of Forestry (2005) for each county in the state. The WVDOF reported a greater number of fires occurring in Fayette County during the spring fire season with the average year in the 1940s and 1950s having 50 fires. Though spring fires burn more often, fall fires have historically accounted for the largest fire years in the county with an average of 6,000 acres burned in each year in the 1950s. The largest fire year happened in 1952 when 118 fall fires burned over 39,000 acres. The present study found $94 \%$ of fires occurred during the dormant season that includes the period of the spring prior to budbreak.

It is possible that other types of disturbances aided in the establishment and maintenance of rimrock pine communities in the New River Gorge. Mining operations and railroad construction fueled the timber industry in the late $19^{\text {th }}$ and early $20^{\text {th }}$ centuries. However, it is unlikely that large portions of the rimrock forest were cut because of the poor quality of timber. 
Other events such as windthrow, ice storms, and insect outbreaks may have resulted in pulses of regeneration that coincided with the pine establishment following fires.

\subsection{Management Suggestions}

Restoring the disturbance regime that has established and maintained the rimrock pine community presents a number of challenges. First, we must ask the question, "Do we want to restore the rimrock pine community to its past dominance or do we want to keep the community within its current range?" The present-day pine component of the rimrock exists largely within the first $20 \mathrm{~m}$ of the cliff edge. However, historic photographs of the rimrock and the presence of dominant Virginia pines up to $300 \mathrm{~m}$ from the cliff edge suggest that the rimrock pine community was, in the first half of the $20^{\text {th }}$ century, a thicker band along the rim of the gorge. For Virginia pine to become a dominant in the canopy away from the cliff edge, disturbances that created suitable growing conditions (i.e., mineral soil and direct sunlight) must have occurred in the past.

A management plan directed at restoring Virginia pine to it's prior extent would include periodic prescribed burning to prepare the seedbed for pine regeneration and suppress deciduous competitors. As previously suggested by Vanderhorst (2002), burning could occur adjacent to the current pine communities ( $>20 \mathrm{~m}$ from cliff edge) to preserve a seed source. Mimicking past fires ignited on the slope of the gorge would not be feasible due to fire control issues and the risk of combusting exposed coal. There has been no research regarding the intensity of prescribed fire needed to regenerate Virginia pine. Research on prescribed burning conducted in Table Mountain pine stands located in the southern Appalachians suggests that multiple low-intensity fires may provide the best conditions for regeneration (Waldrop et al. 2003). Because Virginia pine is considered a thin-barked species that is vulnerable to fire, the survival of fire-scarred 
pines confirms a regime of low-intensity burning (Carter and Snow 1990). Fires should occur during the dormant season prior to budbreak to follow the fire regime of the $20^{\text {th }}$ century; however, fall fires may be more successful at promoting regeneration. A Virginia pine seed dispersal study found that dispersal began between mid-October and early November, and 6090\% of seed fell before January (Church and Sucoff 1960). Thus, burning prior to seedfall may be more effective in establishing pine seedlings in the following growing season. A second prescribed burning method could involve burning patches of the rimrock community to simulate a fire traveling up narrow breaks and low points along the Endless Wall. Initially, burning should occur in non-pine areas that have succeeded into more mesic hardwoods and eastern hemlock. This method would preserve the existing pine seed source adjacent to these areas while suppressing competitors and destroying the hardwood seedbank lying dormant in the soil.

Some questions must be taken into consideration when conducting a prescribed burn within a rimrock community. Is the area accessible to fire personnel and equipment? Is the area used often by visitors? Is the area safely within the park boundary? Is there a risk of the fire escaping to private land? Is smoke management a problem? How will other forest communities and wildlife be impacted? Some of the rimrock communities within the park boundary will be more suitable than others for conducting prescribed burning programs based on the answers to these questions. Resource managers may find that a combination of linear burns adjacent to the existing community and patch burns within community will satisfy the restoration objectives of the park.

Other methods to encourage regeneration of Virginia pine may complement prescribed fire. For instance, herbicide treatments could be used to target hardwood competitors while the seedbed was prepared by mechanical scarification. The amount of herbicides and extent of 
mechanical disturbance necessary to prepare the seedbed introduce additional concerns about the impacts on the ecosystem. Clearcutting strips of forest adjacent to the rimrock community, crop tree management, and other methods of canopy manipulation are more intensive options. While these methods may be highly successful at regenerating pine, they can be expensive, aesthetically unappealing to visitors, and increases susceptibility of residual pines to windthrow. Less intensive management actions could be implemented in addition to prescribed burning. These could involve voluntary and/or mandatory trail closings to halt soil compaction and trampling of pine regeneration and restrictions against using trees as anchors for rock climbing. Finally, there is the option of no action. The rimrock community could be left to succeed into a hardwood dominated forest with Virginia pine existing on the cliff edges and rock outcrops.

\subsection{Future Research}

Implementing a prescribed burning program to restore and maintain the rimrock pine community will require much preparation to ensure management objectives are achieved. The NPS has developed a methodology outlined in the New River Gorge National River Wildland Fire Management Plan (2005) and in the NPS Fire Monitoring Handbook (2003a) that standardizes data collection procedures for fire effects research. Minimum research variables would measure pre- and post-burn vegetation data, leaf litter/duff measurements, soil moisture, consumption of woody debris, flame temperature, and flame height. While much is known about the effects of prescribed fire in mixed-oak (Brose and Van Lear 1998, Yaussy 2000, Brose and Van Lear 2004, Elliott et al. 2004) and ridge-top pine stands (Brose and Waldrop 2000, Welch and Waldrop 2001, Waldrop et al. 2003) of the Central Hardwood Region, their has been little research investigating the effects of prescribed fire on xeric, cliff-edge Virginia pine communities. 
Another issue of concern is the impact of recreational use on cliff-edge forest structure and establishment of tree regeneration (Parikesit et al. 1995, Farris 1998, Larson et al. 2000). The rimrock pine community, located along the Endless Wall, is a popular area for hiking and rock climbing. Increased visitor usage will likely speed the rate of decline of the Virginia pine due to soil compaction, trampling of regeneration, and damage to the existing boles and roots that are used as anchors for rock climbing. In many areas along the gorge, the park boundary extends less than $100 \mathrm{~m}$ from the cliff edge, restricting the ability of the NPS to effectively restore and manage the rimrock pine community. Additionally, NERI faces the new challenge of preserving threatened ecological communities as the surrounding area becomes more desirable for residential development. A future research project investigating the impacts of visitor usage and residential development on the rimrock pine community would be valuable in determining management prescriptions and park policy regarding the location of developments near the park boundary.

The rimrock pine community is not separate from the surrounding ecosystem. The vegetation of the New River Gorge is a mosaic of forest communities and the management of each community will impact the others. For example, the hemlock wholly adelgid (Adelges tsugae) threatens to kill the neighboring eastern hemlock forest that buffers the streams flowing into the rimrock community. The loss of this evergreen species may hasten the hardwood succession near the cliff edge. Also, little is known about the vegetation on the vertical faces of the Endless Wall. Lichens, bryophytes, and canopy species such as Virginia pine, exist along this expansive substrate and may require a different management strategy from the surrounding ecosystems. Canadian researchers have conducted investigations along the Niagara Escarpment in southern Canada studying the effects of rock climbing of cliff vegetation (McMillan and 
Larson 2002), the impact of trails on cliff edge vegetation structure (Parikesit et al. 1995), and the effects of disturbance on old-growth growing on cliff edges (Larson 1991). Similar projects would be beneficial in the description and management of cliff communities within the New River Gorge. The animal population is another segment of the rimrock community which would be affected by management and restoration activities. Allegheny wood rats, peregrine falcons, Virginia big-eared bats, and other species that live within the cliff ecosystem may be affected by the decline of the rimrock pine community.

\subsection{Conclusion}

The goal of the present study was to establish a historic benchmark for rimrock pine communities at the New River Gorge National River through a descriptive analysis of the vegetation, a tree-ring analysis of the age structure and disturbance regime, and the investigation of land use history. It is intended that with this information the NPS will be better able to manage valuable forest resources that are in danger of decline. The management suggestions written above will require modification to meet the multi-faceted goals of preserving the rimrock for future generations. However, the results of the study confirm the need of some type of restoration activity to aid regeneration of rimrock pines and to maintain the historic prevalence of the forest. Without action, the rimrock community will be succeeded by deciduous competitors on all but the poorest sites on the cliff edges and rock outcrops.

The present study is not without limitations and many questions were raised that were beyond the scope of the project. For example, would a spatial analysis of historic photographs taken throughout the $20^{\text {th }}$ century provide evidence to confirm the frequency of disturbance and past abundance of Virginia pine? Is there evidence of wildfire in historic newspapers, magazines, journals, or mining and timber industry documents? Was fire a ubiquitous presence 
in the park or was it confined to the forests on the slopes of the gorge and rimrock areas? To better understand the disturbance regime (i.e., fire frequency, intensity, and extent), additional sampling must occur along the rimrock as well as down the slope of the gorge. Also, sampling in other rimrock pine communities within the park will help determine the impact of anthropogenic fires across the park. It is plausible that the frequency of fires differed in other cliff communities in the park and that the historic prevalence of Virginia pine along the Endless Wall is driven more by its disturbance regime than the edaphic site conditions.

The current rimrock pine community is a valued resource in threat of decline in the New River Gorge National River. Under the mandate of the National Park Service to conserve and interpret the natural, scenic, and historic character of this stretch of the New River Gorge, restoration of the rimrock pine community is vital. The present project is only a snapshot of an ever-changing ecosystem and the maintenance of the rimrock forest will require some type of disturbance (i.e., fire) if it is to be preserved for the enjoyment of future generations. 


\section{LITERATURE CITED}

Abrams, M. D. 1985. Fire history of oak gallery forests in a northeast Kansas tallgrass prairie. American Midland Naturalist 114:188-191.

Abrams, M. D. 1992. Fire and the development of oak forests. Bioscience 42:346-353.

Abrams, M. D. 2000. Fire and the ecological history of oak forests in the eastern United States. Pages 46-55 in D. A. Yaussy, editor. Workshop on Fire, People, and the Central Hardwoods Landscape. USDA Forest Service Northeastern Research Station Gen. Tech. Rep. NE-274, Richmond, KY.

Abrams, M. D., and D. A. Orwig. 1995. Structure, radial growth dynamics and recent climatic variations of a 320-year-old Pinus rigida rock outcrop community. Oecologia 101:353360.

Abrams, M. D., D. A. Orwig, and T. E. Demeo. 1995. Dendroecological analysis of successional dynamics for a presettlement-origin white pine-mixed-oak forest in the southern Appalachians, USA. Journal of Ecology 83:123-133.

Agee, J. K. 1993. Fire Ecology of Pacific Northwest Forests. Island Press, Washington, D.C.

Allen, C. D., M. Savage, D. A. Falk, K. F. Suckling, T. W. Swetnam, T. Schulke, P. B. Stacey, P. Morgan, M. Hoffman, and J. T. Klingle. 2002. Ecological restoration of southwestern pondersosa pine ecosystems: a broad perspective. Ecological Applications 12:1418-1433.

Arno, S. F., and T. D. Peterson. 1983. Variation in estimates of fire intervals: a closer look at fire history on the Bitterroot National Forest. USDA Forest Service Research Paper INT301:8.

Barden, L. S. 1976. Pine reproduction in the Thompson River Watershed, North Carolina. Journal of the Elisha Mitchell Scientific Society 92:110-113.

Braun, E. L. 1950. Deciduous Forests of Eastern North America. Blakiston Co., Philadelphia, PA.

Brooks, A. B. 1910. West Virginia Geological Survey Volume Five: Forestry and Wood Industries. The Acme Publishing Company, Morgantown, WV.

Brose, P., T. Schuler, D. Van Lear, and J. Berst. 2001. Bringing Fire Back: the changing regimes of the Appalachian mixed-oak forests. Journal of Forestry 99:30-35.

Brose, P., F. Tainter, and T. Waldrop. 2002. Regeneration history of three table mountain pine/pitch pine stands in northern Georgia. Pages 290-295 in K. W. Outcalt, editor. 11th Biennial Southern Silvicultural Research Conference. USDA Forest Service Southern Research Station Gen. Tech. Rep. SRS-48., Asheville, NC.

Brose, P., and D. Van Lear. 1998. Responses of hardwood advance regeneration to seasonal prescribed fires in oak-dominated shelterwood stands. Canadian Journal of Forest Research 28:331-339.

Brose, P., and D. Van Lear. 2004. Survival of hardwood regeneration during prescribed fires: the importance of root development and root collar location. Pages 123-127 in M. A. Spetich, editor. Upland oak ecology symposium: history, current conditions, and sustainability. USDA Forest Service Southern Research Station SRS-73, Asheville, NC.

Brose, P., and T. Waldrop. 2000. Using prescribed fire to regenerate Table Mountain pine in the southern Appalachian Mountains. Pages 191-196 in K. Moser and C. Moser, editors. Fire and forest ecology: innovative silviculture and vegetation management, Tall Timbers Fire Ecology Conference, No. 21. Tall Timbers Research Station, Tallahasee, FL. 
Brown, J. K., and J. K. Smith. 2000. Wildland fire in ecosystems: effects on flora. USDA Forest Service Rocky Mountain Research Station Gen. Tech. Rep. RMRS-GTR-2-vol. 2.

Buell, M. F., H. F. Buell, and J. A. Small. 1954. Fire in the history of the Mettler's Woods. Bulletin of the Torrey Botanical Club 81:253-255.

Burkman, W., and W. Bechtold. 1998. Has Virginia pine declined? The use of Forest Health Monitoring and other information in the determination. Pages 258-264 in W. Hansen, Burk, T., editor. Integrated tools for natural resources inventories in the 21 st century: an international conference on the inventory and monitoring of forested ecosystems. USDA Forest Service Gen. Tech. Rep. NCRS-212, Boise, ID.

Carter, K., and A. Snow. 1990. Pinus virginiana Mill. Pages 1-14 in R. Burns and B. Honkala, editors. Silvics of North America: 1 Conifers; 2. Hardwoods. Agriculture Handbook 654, Vol. 2. USDA Forest Service, Washington, D.C.

Church, T. W., and E. I. Sucoff. 1960. Virginia pine seed viable two months before natural cone opening. USDA Forest Service Research Note NE-44.

Clatterbuck, W. K. 1991. Forest development following disturbances by fire and by timber cutting for charcoal production. Pages 60-65 in S. C. Nodvin, Waldrop, T.A., editor. Fire and the Environment: Ecological and Cultural Perspectives. USDA Forest Service Southeastern Experiment Station Gen. Tech. Rep. SE-69. Knoxville, TN.

Cook, E. R., and R. L. Holmes. 1990. User Manual for the program ARSTAN. Laboratory of Tree-ring Research, University of Arizona.

Cutter, B. C., and R. P. Guyette. 1994. Fire frequency on an oak-hickory ridgetop in the Missouri Ozarks. American Midland Naturalist 132:393-398.

Davis, M. B. 1985. Historical considerations. 1. History of the vegetation on the Mirror Lake Watershed. Pages 53-65 in G. E. Likens, editor. An Ecosystem Approach to Aquatic Ecology: Mirror Lake and its Environment. Springer-Verlag, New York.

Delcourt, H. R., and P. A. Delcourt. 1997. Pre-Columbian Native American use of fire on southern Appalachian landscapes. Conservation Biology 11:1010-1014.

Denevan, W. 1992. The pristine myth: the landscape of the Americas in 1492. Annals of the Association of American Geographers 82:369-385.

Dey, D. C., R. P. Guyette, and M. C. Stambaugh. 2004. Fire history of a forest, savanna, and fen mosaic at White Ranch State Forest. in M. A. Spetich, editor. Upland oak ecology symposium: history, current conditions, and sustainability. USDA Forest Service Southern Research Station Gen. Tech. Rep. SRS-73, Asheville, NC.

Dieterich, J. H., and T. W. Swetnam. 1984. Dendrochronology of a fire-scarred ponderosa pine. Forest Science 30:238-247.

Ehle, D. S., and W. L. Baker. 2003. Disturbance and stand dynamics in ponderosa pine forests in Rocky Mountains National Park, USA. Ecological Monographs 73:543-566.

Elliott, K. J., J. M. Vose, B. D. Clinton, and J. D. Knoepp. 2004. Effects of understory burning in a mesic mixed-oak forest of the southern Appalachians. Pages 272-283 in R. T.

Engstrom, Galley, K.E.M., \& de Groot, W.J., editor. 22nd Tall Timbers fire ecology conference: fire in temperate, boreal, and montane ecosystems. USDA Forest Service Tall Timbers Research Station, Tallahassee, FL.

Farris, M. A. 1998. The effects of rock climbing on the vegetation of three Minnesota cliff systems. Canadian Journal of Forest Research 76:1981-1990.

Fenneman, N. M. 1938. Physiography of the Eastern United States. McGraw-Hill, New York. 
Fenton, H., and A. Bond. 1964. The silvics and silviculture of Virginia pine in southern Maryland. USDA Forest Service Research Paper NE-27.

Fritts, H. C., and T. W. Swetnam. 1989. Dendroecology: a tool for evaluating variations in past and present forest environments. Advances in ecological research 19:111-188.

Grafton, W. N. 1982. Plants and vegetation of the New River Gorge. Pages 69-74 in The New River Symposim. National Park Service, New River Gorge National River, Beckley, WV.

Grissino-Mayer, H. D. 2001a. Evaluating crossdating accuracy: a manual and tutorial for the computer program COFECHA. Tree-ring Research 57:205-221.

Grissino-Mayer, H. D. 2001b. FHX2: Software for analyzing temporal and spatial patterns in fire regimes from tree rings. Tree-ring Research 57:115-124.

Grissino-Mayer, H. D., and T. W. Swetnam. 1997. A multi-century history of wildfire in the ponderosa pine forests of El Malpais National Mounment. Pages 163-171 in K. Mabery, editor. The Natural History of El Malpais National Monument. New Mexico Bureau of Mines and Mineral Resources Bulletin, 156: 163-171.

Grissino-Mayer, H. D., and T. W. Swetnam. 2000. Century-scale climate forcing of fire regimes in the American Southwest. The Holocene 10:213-220.

Guyette, R., and M. Stambaugh. 2004. Post-oak fire scars as a function of diameter, growth, and tree age. Forest Ecology and Management 198:183-192.

Guyette, R. P., and B. E. Cutter. 1991. Tree-ring analysis of fire history of a post oak savanna in the Missouri Ozarks. Natural Areas Journal 11:93-99.

Guyette, R. P., and B. E. Cutter. 1997. Fire history, population, and calcium cycling in the Current River watershed. Pages 354-372 in S. G. Pallardy, Cecich, R.A., Garret, H.G., Johnson, P.S., editor. 11 th Central Hardwood Forest Conference. USDA Forest Service Gen. Tech. Rep. NC-188, Columbia, MS.

Guyette, R. P., and D. C. Dey. 1997. Fire and logging history at Huckleberry Hollow, Shannon County, Missouri. Missouri Dept. of Conservation, Jefferson City, Missouri. Forest Research Report No. 1.

Guyette, R. P., and E. A. McGinnes. 1982. Fire history of an Ozark glade in Missouri. Transactions, Missouri Academy of Science 16:85-93.

Guyette, R. P., and M. A. Spetich. 2003. Fire history of oak-pine forests in the lower Boston Mountians, Arkansas USA. Forest Ecology and Management 180:463-474.

Guyette, R. P., and M. Stambaugh. 2002. Fire history of Panther Cave Hollow. Pages 27-39 in G. Hartman, Holst, S., Palmer, B., editor. Society for Range Management 2002: Savanna/Woodland Symposium, Kansas City, Missouri.

Harmon, M. 1982. Fire history of the westernmost portion of Great Smoky Mountains National Park. Bulletin of the Torrey Botanical Club 109:74-79.

Henderson, N. R., and J. N. Long. 1984. A comparison of stand structure and fire history in two black oak woodlands in northwestern Indiana. Botanical Gazette 145:222-228.

Hengst, G. E., and J. O. Dawson. 1994. Bark properties and fire resistance of selected tree species from the cental hardwood region of North America. Canadian Journal of Forest Research 24:688-696.

Hermann, S. M. 1993. 18th Tall Timbers Fire Ecology Conference: The longleaf pine ecosystem- ecology, restoration, and management. Tallahassee, Florida

Hessl, A., and S. Spackman. 1995. Effects of fire on threatened and endangered plants: an annotated bibliography. USDA National Biological Service Information and Technology Report 2. 
Heyerdahl, E. K., L. B. Brubaker, and J. K. Agee. 2001. Spatial controls of historical fire regimes: a mulitscale example from the interior west, USA. Ecology 82:660-678.

Hicks, R. R. 1998. Ecology and Management of Central Hardwood Forests. John Wiley \& Sons, New York.

Hicks, R. R. 2000. Humans and fire: a history of the Central Hardwoods. Pages 3-18 in D. A. Yaussy, editor. Workshop on Fire, People, and the Central Hardwoods Landscape. USDA Forest Service Northeastern Research Station, RIchmond, KY.

Hicks, R. R., and D. A. Mudrick. 1993. Forest health 1993: a status report for West Virginia. WV Dept. of Agriculture, Charleston, WV.

Hough, A. F. 1960. Silvical characteristics of eastern hemlock (Tsuga canadensis). USDA Forest Service Research Paper Ne-132:23.

Jenkins, S. E., R. Guyette, and A. J. Rebertus. 1997. Vegetation-site relationships and fire history of a savanna-glade-woodland mosaic in the Ozarks. Pages 184-201 in S. G. Pallardy, Cecich, R.A., Garret, H.G., Johnson, P.S., editor. 11th Central Hardwood Conference. USDA Forest Service Northcentral Experiment Station, St. Paul, MN.

Jenkins, T. 2005. Rimrock soils report. Natural Resource Conservation Service. Unpublished. Johnson, P. G. 1983. The New River Early Settlement. Walpa Publishing, Blacksburg, VA.

Keeley, J. E. 2002. Native American impacts on fire regimes of California coastal ranges. Journal of Biogeography 29:303-320.

Lafon, C. W., J. A. Hoss, and H. D. Grissino-Mayer. 2005. The contemporary fire regime of the central Appalachian Mountains and its relation to climate. Physical Geography 26:126146.

Larson, D. W. 1991. Effects of disturbance on old-growth Thuja occidentalis at cliff edges. Candian Journal of Botany 68:1147-1155.

Larson, D. W., U. Matthes, and P. E. Kelly. 2000. Cliff ecology: pattern and process in cliff ecosystems. Cambridge University Press, Cambridge, United Kingdom.

Lessing, P. 1986. Geology of the New River Gorge. Mountian State Geology.

Lorimer, C. G. 1985. The role of fire in the perpetuation of oak forests. Pages 8-25 in J. Johnson, editor. Challenges in oak management and utilization. University of Wisconsin Cooperative Extension Service, Madison.

Lorimer, C. G., and L. E. Frehlich. 1989. A methodology for estimating canopy disturbance frequency and intensity in dense temperate forests. Candian Journal of Forest Research 19:651-663.

Luther, E. T. 1977. Our restless earth. University of Tennessee.

Maddex, L. R. 1992. Nuttalburg mine complex: a case study in mining technology. Pages 20-27 in The New River Symposium. National Park Service, New River Gorge National River, Beckley, WV.

Mahan, C. G. 2004. A natural resource assessment for New River Gorge National River, Natural Resource Report NPA/NERCHAL/NRR-04/006. National Park Service, New River Gorge National River, West Virginia.

Marshall, P. D., and D. N. Fuerst. 1982. Inventorying the New River: an archeological, historical and architectural survey. Pages 61-68 in The New River Symposium. National Park Service, New River Gorge National River, Beckley, WV.

Marwitt, J. P. 1982. Test Excavations at three late prehistoric village sites at Bluestone Lake, Summers County, West Virginia. Pages 195-197 in The New River Symposium. National Park Service, New River Gorge National River, Beckley, WV. 
Maslowski, R. F. 1982. Archeology of the Bluestone Reservation. Pages 185-194 in The New River Symposium. National Park Service, New River Gorge National River, Beckley, WV.

McCune, B., J. B. Grace, and D. L. Urban. 2002. Analysis of Ecological Communities. MJM Software Design

Gleneden Beach, Oregon.

McCune, B., and M. J. Mefford. 1999. PCORD for windows: multivariate analysis of ecological data, version 4.0. MjM Software, Glenedon Beach, OR.

McMillan, M. A., and D. W. Larson. 2002. Effects of rock climbing on the vegetation of the Niagara Escarpment in southern Ontario, Canada. Conservation Biology 16:389-398.

Morgan, P., C. C. Hardy, T. W. Swetnam, M. G. Rollins, and D. G. Long. 2001. Mapping fire regimes across time and space: understanding coarse and fine-scale fire patterns. International Journal of Wildland Fire 10:329-342.

Moritz, M. A. 2003. Spatiotemporal analysis of controls on shrubland fire regimes: age dependency and fire hazard. Ecology 84:351-361.

National Oceanic and Atmospheric Administration. 2005. http://www.noaa.gov/index.html. United States Department of Commerce.

National Park Service. 2003a. Fire Monitoring Handbook. Boise, ID: Fire Management Program Center, National Interagency Fire Center. United States Department of Agriculture, National Park Service, Boise, ID.

National Park Service. 2003b. Workshop to Identify Significant Forest Issues, Resources, and Processes. USDA National Park Service, New River Gorge National River, Glen Jean, WV.

National Park Service. 2005. New River Gorge National River Wildland Fire Management Plan. USDA National Park Service, New River Gorge National River, Glen Jean, WV.

Natural Resources Conservation Service. 2005. United States Department of Agriculture.

Nowacki, A. G., and M. D. Abrams. 1991. Community and edaphic analysis of mixed oak forests in the Ridge and Valley province of central Pennsylvania. Pages 247-260 in L. H. McCormick, Gottschalk, K.W, editor. 8th Central Hardwood Forest Conference. USDA Forest Service Gen. Tech Report Northeast Research Station, Pennsylvania State University.

Nowacki, A. G., and M. D. Abrams. 1997. Radial-growth averaging criteria for reconstructing disturbance histories from presettlement-origin oaks. Ecological Monographs 67:225249.

Ohmann, L. F., and M. F. Buell. 1968. Forest vegetation of the New Jersey Highlands. Bulletin of the Torrey Botanical Club 95:287-298.

Parikesit, P. D., D. W. Larson, and U. Matthes-Sears. 1995. Impacts of trails on cliff-edge forest structure. Canadian Journal of Botany 73.

Peters, J. T., and H. B. Carden. 1926. History of Fayette County, West Virginia. The Fayette County Historical Society, Fayetteville, WV.

Phipps, R. L. 1985. Collecting, preparing, crossdating, and measuring tree increment cores. US Geological Survey. Water-Resources Investigations 85-4148.

Pyne, S. 1982. Fire in America: A Cultural History of Wildland and Rural Fire. Princeton University Press, Princeton.

Pyne, S. J., P. L. Andrews, and R. D. Laven. 1996. Introduction to Wildland Fire, Second edition. John Wiley \& Sons, New York. 
Rice, O. K. 1985. West Virginia: a history. The University Press of Kentucky, Lexington, KY.

Romme, W. 1980. Fire history terminology: report of the ad hoc committee. Fire History Workshop. Tucson, Arizona. Laboratory of Tree-ring Research, University of Arizona.

Ruffner, C. M., and J. W. Groninger. 2006. Making the case for fire in southern Illinois forests. Journal of Forestry 104.

Schuler, T. M., and W. R. McClain. 2003. Fire history of a ridge and valley oak forest. USDA Forest Service Northeastern Research Station Research Paper NE-724.

Shifley, S. R., and B. L. Brookshire. 2000. Missouri Ozark Forest Ecosystem Project: site history, soils, landforms, woody and herbaceous vegetation, down wood, and inventory methods for the landscape experiment. USDA Forest Service North Central Research Station Gen. Tech. Rep. NC-208.

Shumway, D. L., M. D. Abrams, and C. M. Ruffner. 2001. A 400-year history of fire and oak recruitment in an old-growth oak forest in western Maryland, U.S.A. Canadian Journal of Forest Research 31:1437-1443.

Smith, D. M., B. C. Larson, M. J. Kelty, and P. M. Ashton. 1997. The practice of silviculture: applied forest ecology, ninth edition. John Wiley and Sons, New York, New York.

Smith, K. T., and E. K. Sutherland. 1999. Fire-scar formation and compartmentalization in oak. Canadian Journal of Forest Research 29:166-171.

Smith, K. T., and E. K. Sutherland. 2001. Terminology and biology of fire scars in selected central hardwoods. Tree-ring Research 57:141-147.

Society of American Foresters. 1980. Forest Cover Types of the United States and Canada. Society of American Foresters, Washington, D.C.

Soucy, R. D., E. Heitzman, and M. A. Spetich. 2005. The establishment and development of oak forests in the Ozark Mountains of Arkansas. Canadian Journal of Forest Research 35:1790-1797.

Stambaugh, M., R. Guyette, and C. Putnam. 2005. Fire in the pines. Park Science 23:43-47.

Stokes, M. A. 1980. The dendrochronology of fire history. Stokes, M.A. and J.H. Dieterich, editors. Fire History Workshop. Tuscon, AZ. USDA Forest Service Gen. Tech Rep. RM81

Stokes, M. A., and T. L. Smiley. 1968. An introduction to tree-ring dating. University of Arizona Press, Tucson, AZ.

Sucoff, E. I. 1961. Effect of seedbed preparation on regeneration of Virginia pine after logging. USDA Forest Service Station Paper NE-147.

Suiter, D. W., and D. K. Evans. 1995. Vascular flora and rare species of New River Gorge National River, West Virginia. Castanea 64:23-49.

Sutherland, E. K. 1997. History of fire in a southern Ohio second-growth mixed-oak forest. Pages 172-183 in S. G. Pallardy, Cecich, R.A., Garret, H.G., Johnson, P.S., editor. 11th Central Hardwood Conference. USDA Forest Service North Central Experiment Station, St. Paul, MN.

Sutherland, E. K., H. Grissino-Mayer, C. A. Woodhouse, W. W. Covington, S. S. Horn, L. Huckaby, R. Kerr, J. Kush, M. Moorte, and T. Plumb. 1993. Two centuries of fire in a southwestern Virginia Pinus pungens Community in Hypertext Proceedings, 1993 June 21-24. University Park, PA. Pennsylvania State University, Center for Statistical Ecology and Environmental Statistics. 
Swetnam, T. W. 1990. Fire history and climate in the southwestern United States. Pages 6-17 in J. S. Krammes, editor. Effects of Fire Management of Southwestern Natural Resources, Proceedings of the Symposium. USDA Forest Service Gen. Tech. Report RM-191.

Swetnam, T. W., and C. H. Baisan. 1996. Historical fire regime patterns in the southwestern United States since 1700. Pages 11-32 in C. D. Allen, editor. Fire effects in southwestern forests, Proceedings of the 2nd La Mesa Fire Symposium. USDA Forest Service Gen. Tech. Report RM-GTR-286, Los Alamos, NM.

United States Department of Agriculture. 1975. Soil Survey of Fayette and Raleigh Counties, West Virginia. USDA Soil Conservation Service, Washington, D.C.

Unrau, H. D. 1996. Special history study/historic context study: New River Gorge National River, WV. USDA National Park Service, New River Gorge National River, Glen Jean, WV.

Van Lear, D. H. 1984. Prescribed fire: its history, uses, and effects in southern forest ecosystems. in Prescribed Fire and Smoke Management in the South, Atlanta, GA.

Van Lear, D. H., and T. A. Waldrop. 1989. History, uses, and effects of fire in the Appalachians. USDA Forest Service Southeastern Research Station Gen. Tech. Rep. SE-54.

Van Lear, D. H., and J. M. Watt. 1993. The role of fire in oak regeneration. Pages 66-78 in D. L. Loftis, McGee, C.E., editor. Proceedings of oak regeneration: serious problems, practical recommendations. USDA Forest Service Gen. Tech Report SE-84, Knoxville, TN.

Vanderhorst, J. 2001. Plant communities of the New River Gorge National River, West Virginia (northern and southern thirds). Final report for the NPS. West Virginia Natural Heritage Program. Elkins, WV.

Vanderhorst, J. 2002. Two cliff top pine communities in the north section of the New River Gorge National River, West Virginia. USDA National Park Service, New River Gorge National River, Glen Jean, WV.

Veblen, T. T., T. Kitzberger, and J. Donnegan. 2000. Climatic and human influences on fire regimes in ponderosa pine forests in the Colorado Front Range. Ecological Applications 10:1178-1195.

Veysey, J., M. Ayres, M. Lombardero, R. Horstetter, and K. Klepzig. 2003. Relative suitability of Virginia pine and loblolly pine as host species for Dendroctonus frontalis (Coleoptera: Scolytidae). Environmental Entomology 32:668-679.

Wade, D. D., B. L. Brock, P. H. Brose, J. B. Grace, G. A. Hoch, and W. A. Patterson III. 2000. Chapter 4: Fire in Eastern Ecosystems. Pages 53-96 in J. K. Brown, Smith, J.K., editor. Wildland fire in ecosystems: effects of fire on flora. USDA Forest Service Rocky Mountain Research Station Gen. Tech. Rep RMRS-GTR-42-vol.2. Ogden, UT.

Waldrop, T., P. Brose, N. Welch, H. Mohr, E. Gray, F. Tainter, and L. Ellis. 2003. Are crown fires necessary for Table Mountain pine? Pages 157-163 in K. Galley, Klinger, R., Sugihara, N., editor. Fire Conference 2000: The First National Congress of Fire Ecology, Prevention, and Management. Tall Timbers Research Station, Tallahassee, FL.

Warrillow, M., and P. Mou. 1999. Ice storm damage to forest tree species in the ridge and valley region of southwestern Virginia. Journal of the Torrey Botanical Society 126:147-158.

Watts, W. A. 1980. Late quaternary vegetation of the central Appalachian and the New Jersey coastal plain. Ecological Monographs 49:427-469.

Welch, N. T., and T. A. Waldrop. 2001. Restoring Table Mountain pine (Pinus pungens Lamb.) communities with prescribed fire: an overview of current research. Castanea 66:42-49.

West Virginia Division of Forestry. 2005. Fire records for West Virginia. Unpublished. 
White, P. S., and A. Jentsch. 2001. The search for generality in studies of disturbance and ecosystem dynamics. Pages 399-450 in Progress in Botany. Springer-Verlag, Berlin, Germany.

Whittaker, R. H. 1956. A consideration of climax theory: the climax as a population and pattern. Ecological Monographs 23:41-78.

Williams, C. E., and W. C. Johnson. 1990. Age structure and the maintenance of Pinus pungens in pine-oak forests of southwestern Virginia. American Midland Naturalist 124:130-141.

Yaussy, D. A. 2000. Fire, people, and the central hardwood landscape. USDA Forest Service Gen. Tech. Rep. NE-274.

Zobel, D. 1969. Factors affecting the distribution of Pinus pungens: an Appalachian endemic. Ecological Monographs 39:303-333. 


\title{
CURRICULUM VITAE
}

\author{
Richard Stockton Maxwell \\ 385 Evans Street \\ Morgantown, WV 26505 \\ Home Phone: (304) 280-8565 \\ Email: rmaxwell@mix.wvu.edu
}

\section{Educational History}

1994 - 1998: Linsly School, Wheeling, WV

Degree: High School Diploma

GPA: 4.00

1998 - 2002: West Virginia University, Morgantown, WV

Major: Psychology

Specialization: Behavior Analysis

Degree: B.A.

Honors Thesis: Experimenters as Social Discriminative Stimuli

Honors Advisor: Kennon A. Lattal, Ph.D.

GPA: 3.82

2004 - 2006: West Virginia University, Morgantown, WV

Major: Forestry

Specialization: Forest Ecology

Degree: M.S.F

Master's Thesis: Establishing a Historic Benchmark for Rimrock Pine Communities at the New River Gorge National River, West Virginia.

Advisor: Ray R. Hicks, Jr., Ph.D.

GPA: 4.00

\section{Professional Experience}

March 2003 - June 2004: Research Assistant (Psychiatry), Temple University, Philadelphia, PA Supervisor: Ralph Spiga, Ph.D., Researcher and Professor of Psychology.

Primary duties: Research coordination including data collection and analysis, preparation of manuscripts for publication in scientific journals, and development of research protocols and informed consents.

Secondary duties: Office management including employee training, purchasing, and grant management.

November 2004 - November 2005: Research Collaborator, Ray R. Hicks, Jr., Ph.D (Private Consultant and Professor of Forest Ecology, West Virginia University).

Supervisor: Ray R. Hicks, Jr., Ph.D. 
Primary duties: Forest measurements of research plots.

March 2005 - September 2005: Research Collaborator, West Virginia University and National Park Service.

Supervisor: Ray R. Hicks, Jr., Ph.D., Professor of Forest Ecology.

Primary duties: Conceptual development of "Vital Signs" for the Eastern Mountains and Rivers Network (NPS) Inventory and Monitoring project, conducting a literature review, and presentation preparation (e.g., PowerPoint, meeting organization, materials, etc.).

August 2005 - Present: Graduate Research Assistant, West Virginia University, Morgantown, WV.

Supervisor: Ray R. Hicks, Jr., Ph.D., Researcher and Professor of Forest Ecology.

Primary duties: Developed, wrote, and received funding for master's thesis research proposal (National Park Service). Experience conducting vegetation surveys, using GPS, increment core and cross section collection, dendrochronological analysis, and statistical analysis of data. Prepare manuscripts for publication in scholarly journals.

May 2006 - August 2006: Field Crew Leader, West Virginia University, Morgantown, WV Supervisor: Eric Heitzman, Ph.D., Researcher and Professor of Silviculture

Primary duties: Identify sample locations, produce field maps with ArcGIS, supervise crew, collect tree measurements, collect increment cores, date tree rings, and analyze stand data.

\section{Research Experience}

Spring 2001: Undergraduate Research Assistant, West Virginia University, Morgantown, WV Supervisor: Kennon A. Lattal, Ph.D.

Research Area: Experimental Analysis of Behavior

Duties: Collected and analyzed data, laboratory animal care, and read and discussed related literature.

2001 - 2002: Honors Thesis, West Virginia University, Morgantown, WV

Supervisor: Kennon A. Lattal, Ph.D.

Title: Experimenters as Social Discriminative Stimuli

Duties: Proposed and defended a written thesis, presented research in poster presentation in front of departmental faculty, collected and organized data, and collaborated with faculty advisor and graduate student.

March 2003 - June 2004: Research Assistant (Psychiatry), Temple University, Philadelphia, PA Supervisor: Ralph Spiga, Ph.D.

Research Projects: Mental Illness and Drug Abuse: Behavioral Treatments, The Effects of

Serotonin on Cooperative Behavior, Experience of Schizophrenia, Cognition and Schizophrenia, Hydrocodone Clinical Drug Trial

Duties: Interviewed participants dually diagnosed with mental illness and drug addiction, collected and analyzed data, and development of psychological assessments.

August 2004 - August 2006: Master's Thesis, West Virginia University, Morgantown, WV 
Supervisor: Ray R. Hicks, Jr., Ph.D.

Title: Establishing a Historic Benchmark for Rimrock Pine Communities at the New River Gorge National River, West Virginia.

Duties: Development of research design and methods, written grant proposal to the National Park

Service and West Virginia University, and data collection and analysis (in progress).

July 2005: Fieldwork Assistant, Joint project between University of Tennessee, Texas A\&M, \& The Nature Conservancy, Narrows, VA.

Supervisors: Herni Grissino-Mayer, Ph.D (University of Tennessee) \& Charles Lafon, Ph.D

(Texas A\&M).

Title: A fire history of Peter's Mountain, Virginia.

Duties: Data collection (increment cores and cross sections).

\section{Publications}

Spiga, R., Maxwell, R.S., Meisch, R.A., \& Grabowski, J. (2005). Human methadone selfadministration and the generalized matching law. The Psychological Record, 55: 525538.

\section{Poster Presentations}

Maxwell, R.S. \& Doughty, A.H. (2001). Preference for variability in pigeons. Eberly College of Arts and Sciences Research Fair. West Virginia University, Morgantown, WV.

Spiga, R., Maxwell, R.S., Meisch, R., Grabowski, J. (2004). Human methadone selfadministration and the generalized matching law. Association for Behavior Analysis International Conference. Boston, MA.

Maxwell, R.S. \& Spiga, R. (2004). Methadone-maintained patients prefer a methadone/ benzodiazepine combinations to either drug alone. Association for Behavior Analysis International Conference. Boston, MA.

Maxwell, R.S. \& Hicks, Jr., R.R. (2005). Establishing a historic benchmark for rimrock pine communities at the New River Gorge National River, West Virginia. Davis College of Agriculture, Forestry, and Consumer Sciences Ninth Annual Graduate Student Research Conference. West Virginia University, Morgantown, WV.

Maxwell, R.S. \& Hicks, Jr., R.R. (2005). Establishing a historic benchmark for rimrock pine communities at the New River Gorge National River, West Virginia. Sigma Xi Graduate Research Day. West Virginia University, Morgantown, WV.

\section{Seminars \& Symposiums}

Spiga, R., Haas, D., Maxwell, R.S., Perrin, F.A., \& Progar, P. International Symposium: Demand effects on preference in human free operant responding. Association for Behavior Analysis International Conference. Boston, MA.

Maxwell, R.S. \& Hicks, Jr., R.R. (2005). Graduate Seminar: Establishing a historic benchmark for rimrock pine communities at the New River Gorge National River, West Virginia. Davis College of Agriculture, Forestry, and Consumer Sciences. West Virginia University, Morgantown, WV. 
Awards

1997 - 1998: West Virginia Top of the Mountain Academic Scholar

1999 - 2002: Presidential Award for Excellence in Scholarship, West Virginia University

2000 - Present: Golden Key National Honor Society

2002: Certificate of Achievement for Academic Excellence, West Virginia University

2002: Magna cum laude, West Virginia University

Membership in Professional Organizations

2000 - 2004: Psi Chi National Honor Society

2003 - 2004: Delaware Valley Association for Behavior Analysis

2003 - 2004: Association for Behavior Analysis

2004 - Present: Society of American Foresters

2004 - Present: Southern Appalachian Man and Biosphere Foundation

2006 - Present: Gamma Sigma Delta member (Agricultural Honors Society)

Teaching/Supervisory Experience

1996 - 1998: Tutor, James Paige Learning Center, Wheeling, WV

Fall 1999: Teaching Assistant, Research Methods in Psychology, Department of Psychology, West Virginia University.

March 2003 - June 2004: Employee Training, Department of Psychiatry Temple University.

Specialized Training and Continuing Education-

2001: Certificate of Achievement: Humane Care and Use of Laboratory Animals in Biomedical Research, West Virginia University

2002: Wilderness First Responder Certification, Stonehearth Open Learning Opportunities

(SOLO)

2002-2006: American Heart Association CPR Certification

2003: HIPPA Certification to conduct research involving human participants, Temple University 2003: Microsoft Excel Certificate, Temple University

2004: SPSS Certificate, Temple University

2004: National Association of Underwater Instructors (NAUI) Scuba Diver Certification

2005: North American Dendroecology Fieldweek (McCall, Idaho)

\section{Skills}

Basic proficiency in written and spoken German

Computer Literacy- Microsoft Office, SPSS, SAS, ArcGIS, etc.

Training in Dendrochronology- data collection and analysis 


\section{References-}

Ray R. Hicks, Jr., Ph.D.

West Virginia University

Division of Forestry

P.O. Box 6125

Morgantown, WV 26505-6125

Phone: 304-293-2941 x.2424

Fax: 304-293-2441

Email: rhicks3@wvu.edu

James Rentch, Ph.D.

West Virginia University

Division of Forestry

P.O. Box 6125

Morgantown, WV 26505-6125

Phone: 304-293-2941 x. 2480

Fax: 304-293-2441

Email: jrentch2@wvu.edu

Amy Hessl, Ph.D.

West Virginia University

Department of Geology and Geography

P.O. Box 6300

Morgantown, WV 26506-6300

Phone: 304-293-5603 x.4344

Fax: 304-293-6522

Email: ahessl@geo.wvu.edu 